Cochrane Database of Systematic Reviews

\title{
Dressings and topical agents for preventing pressure ulcers
} (Review)

Moore ZEH, Webster J

Moore ZEH, Webster J.

Dressings and topical agents for preventing pressure ulcers.

Cochrane Database of Systematic Reviews 2018, Issue 12. Art. No.: CD009362.

DOI: 10.1002/14651858.CD009362.pub3.

www.cochranelibrary.com 
TABLE OF CONTENTS

HEADER 1

ABSTRACT

PLAIN LANGUAGE SUMMARY ....

SUMMARY OF FINDINGS

BACKGROUND

OBJECTIVES

METHODS

Figure 1.

RESULTS

Figure 2.

Figure 3.

Figure 4.

Figure 5.

Figure 6.

DISCUSSION

AUTHORS' CONCLUSIONS

ACKNOWLEDGEMENTS

REFERENCES

CHARACTERISTICS OF STUDIES

DATA AND ANALYSES

Analysis 1.1. Comparison 1 Fatty acid versus other topical intervention or standard care, Outcome 1 Pressure ulcer. ..............

Analysis 1.2. Comparison 1 Fatty acid versus other topical intervention or standard care, Outcome 2 Pressure ulcer (high-quality studies).

Analysis 1.3. Comparison 1 Fatty acid versus other topical intervention or standard care, Outcome 3 Adverse event. ..............

Analysis 2.1. Comparison 2 Active topical agent versus placebo/control, Outcome 1 Pressure ulcer.

Analysis 2.2. Comparison 2 Active topical agent versus placebo/control, Outcome 2 Pressure ulcer stage.

Analysis 2.3. Comparison 2 Active topical agent versus placebo/control, Outcome 3 Adverse event.

Analysis 3.1. Comparison 3 Silicone dressing versus no dressing, Outcome 1 Any pressure ulcer.

Analysis 3.2. Comparison 3 Silicone dressing versus no dressing, Outcome 2 Pressure ulcer (high-quality studies).

Analysis 3.3. Comparison 3 Silicone dressing versus no dressing, Outcome 3 Pressure ulcer stage.

Analysis 4.1. Comparison 4 Other dressing versus control, Outcome 1 Pressure ulcer. ADDITIONAL TABLES

APPENDICES

WHAT'S NEW

CONTRIBUTIONS OF AUTHORS

DECLARATIONS OF INTEREST

SOURCES OF SUPPORT

DIFFERENCES BETWEEN PROTOCOL AND REVIEW

INDEX TERMS 
[Intervention Review]

\title{
Dressings and topical agents for preventing pressure ulcers
}

\author{
Zena EH Moore ${ }^{1}$, Joan Webster2,3,4
}

1School of Nursing \& Midwifery, Royal College of Surgeons in Ireland, Dublin, Ireland. ${ }^{2}$ National Centre of Research Excellence in Nursing, Centre for Health Practice Innovation, Menzies Health Institute Queensland, Griffith University, Brisbane, Australia. ${ }^{3} \mathrm{School}$ of Nursing and Midwifery, The University of Queensland, Brisbane, Australia. ${ }^{4}$ Nursing and Midwifery Research Centre, Royal Brisbane and Women's Hospital, Herston, Australia

Contact address: Zena EH Moore, School of Nursing \& Midwifery, Royal College of Surgeons in Ireland, 123 St. Stephen's Green, Dublin, D2, Ireland.zmoore@rcsi.ie.

Editorial group: Cochrane Wounds Group.

Publication status and date: New search for studies and content updated (conclusions changed), published in Issue 12, 2018.

Citation: Moore ZEH, Webster J. Dressings and topical agents for preventing pressure ulcers. Cochrane Database of Systematic Reviews 2018, Issue 12. Art. No.: CD009362. DOI: 10.1002/14651858.CD009362.pub3.

Copyright @ 2018 The Cochrane Collaboration. Published by John Wiley \& Sons, Ltd.

\section{A B S T R A C T}

\section{Background}

Pressure ulcers, localised injuries to the skin or underlying tissue, or both, occur when people cannot reposition themselves to relieve pressure on bony prominences. These wounds are difficult to heal, painful, expensive to manage and have a negative impact on quality of life. Prevention strategies include nutritional support and pressure redistribution. Dressing and topical agents aimed at prevention are also widely used, however, it remains unclear which, if any, are most effective. This is the first update of this review, which was originally published in 2013.

\section{Objectives}

To evaluate the effects of dressings and topical agents on pressure ulcer prevention, in people of any age, without existing pressure ulcers, but considered to be at risk of developing one, in any healthcare setting.

\section{Search methods}

In March 2017 we searched the Cochrane Wounds Group Specialised Register, CENTRAL, MEDLINE, MEDLINE (In-Process \& Other NonIndexed Citations), Embase, and EBSCO CINAHL Plus. We searched clinical trials registries for ongoing trials, and bibliographies of relevant publications to identify further eligible trials. There was no restriction on language, date of trial or setting. In May 2018 we updated this search; as a result several trials are awaiting classification.

\section{Selection criteria}

We included randomised controlled trials that enrolled people at risk of pressure ulcers.

\section{Data collection and analysis}

Two review authors independently selected trials, assessed risk of bias and extracted data.

\section{Main results}

The original search identified nine trials; the updated searches identified a further nine trials meeting our inclusion criteria. Of the 18 trials (3629 participants), nine involved dressings; eight involved topical agents; and one included dressings and topical agents. All trials reported the primary outcome of pressure ulcer incidence.

\section{Topical agents}


There were five trials comparing fatty acid interventions to different treatments. Two trials compared fatty acid to olive oil. Pooled evidence shows that there is no clear difference in pressure ulcer incidence between groups, fatty acid versus olive oil ( 2 trials, $n=1060$; RR 1.28, 95\% $\mathrm{Cl} 0.76$ to 2.17 ; low-certainty evidence, downgraded for very serious imprecision; or fatty acid versus standard care ( 2 trials, $n=187 ; \mathrm{RR} 0.70$, $95 \% \mathrm{Cl} 0.41$ to 1.18; low-certainty evidence, downgraded for serious risk of bias and serious imprecision). Trials reported that pressure ulcer incidence was lower with fatty acid-containing-treatment compared with a control compound of trisostearin and perfume (1 trial, $\mathrm{n}=331$; RR $0.42,95 \% \mathrm{Cl} 0.22$ to 0.80 ; low-certainty evidence, downgraded for serious risk of bias and serious imprecision). Pooled evidence shows that there is no clear difference in incidence of adverse events between fatty acids and olive oil ( 1 trial, $\mathrm{n}=831 ; \mathrm{RR} 2.22 \mathrm{95} \% \mathrm{Cl} 0.20$ to 24.37 ; low-certainty evidence, downgraded for very serious imprecision).

Four trials compared further different topical agents with placebo. Dimethyl sulfoxide (DMSO) cream may increase the risk of pressure ulcer incidence compared with placebo ( 1 trial, $n=61$; RR $1.99,95 \% \mathrm{Cl} 1.10$ to 3.57 ; low-certainty evidence; downgraded for serious risk of bias and serious imprecision). The other three trials reported no clear difference in pressure ulcer incidence between active topical agents and control/placebo; active lotion ( 1 trial, $n=167$; RR $0.73,95 \% \mathrm{Cl} 0.45$ to 1.19 ), Conotrane ( 1 trial, $\mathrm{n}=258 ; \mathrm{RR} 0.74,95 \% \mathrm{Cl} 0.52$ to 1.07), Prevasore ( 1 trial, $n=120 ; R R ~ 0.33,95 \% \mathrm{Cl} 0.04$ to 3.11 ) (very low-certainty evidence, downgraded for very serious risk of bias and very serious imprecision). There was limited evidence from one trial to determine whether the application of a topical agent may delay or prevent the development of a pressure ulcer (Dermalex TM 9.8 days vs placebo 8.7 days). Further, two out of 76 reactions occurred in the Dermalex ${ }^{\mathrm{TM}}$ group compared with none out of 91 in the placebo group (RR 6.14, $95 \% \mathrm{Cl} 0.29$ to 129.89 ; very low-certainty evidence; downgraded for very serious risk of bias and very serious imprecision).

\section{Dressings}

Six trials $(n=1247)$ compared a silicone dressing with no dressing. Silicone dressings may reduce pressure ulcer incidence (any stage) (RR $0.25,95 \% \mathrm{Cl} 0.16$ to 0.41 ; low-certainty evidence; downgraded for very serious risk of bias). In the one trial ( $n=77$ ) we rated as being at low risk of bias, there was no clear difference in pressure ulcer incidence between silicone dressing and placebo-treated groups (RR 1.95, 95\% $\mathrm{Cl} 0.18$ to 20.61 ; low-certainty evidence, downgraded for very serious imprecision).

One trial $(n=74)$ reported no clear difference in pressure ulcer incidence when a thin polyurethane dressing was compared with no dressing (RR $1.31,95 \% \mathrm{Cl} 0.83$ to 2.07). In the same trial pressure ulcer incidence was reported to be higher in an adhesive foam dressing compared with no dressing (RR $1.65,95 \% \mathrm{Cl} 1.10$ to 2.48 ). We rated evidence from this trial as very low certainty (downgraded for very serious risk of bias and serious imprecision).

Four trials compared other dressings with different controls. Trials reported that there was no clear difference in pressure ulcer incidence between the following comparisons: polyurethane film and hydrocolloid dressing ( $n=160, \mathrm{RR} 0.58,95 \% \mathrm{Cl} 0.24$ to 1.41 ); Kang' huier versus routine care $n=100$; RR $0.42,95 \% \mathrm{Cl} 0.08$ to 2.05); 'pressure ulcer preventive dressing' (PPD) versus no dressing ( $n=74 ; \mathrm{RR} 0.18,95 \% \mathrm{Cl} 0.04$ to 0.76 ) We rated the evidence as very low certainty (downgraded for very serious risk of bias and serious or very serious imprecision).

\section{Authors' conclusions}

Most of the trials exploring the impact of topical applications on pressure ulcer incidence showed no clear benefit or harm. Use of fatty acid versus a control compound (a cream that does not include fatty acid) may reduce the incidence of pressure ulcers. Silicone dressings may reduce pressure ulcer incidence (any stage). However the low level of evidence certainty means that additional research is required to confirm these results.

\section{PLAIN LANGUAGE SUMMARY}

\section{Dressings and topical agents (creams or lotions) for preventing pressure ulcers}

\section{Review question}

We reviewed the evidence about whether dressings and topical agents, like creams, can prevent pressure ulcers.

\section{Background}

Pressure ulcers, also known as bed sores or pressure sores, are injuries to the skin or tissue underneath, or both. They develop as a result of sustained pressure on bony parts of the body. They are common among elderly people and those with mobility problems. They are often difficult to heal, expensive to treat and have a negative impact on people's quality of life, so it is important to prevent them. Special mattresses, cushions, and regular changes of position are used for prevention. Dressings and creams are also widely used. We wanted to compare different dressings and topical agents and find out which were best at preventing pressure ulcers in people at risk of developing them. We also wanted to consider other outcomes, like pain, quality of life, and the cost to healthcare systems of the different treatments.

\section{Trial characteristics}

In order to ensure that the information contained within this review is up to date, in March 2017 we searched for any new randomised controlled trials (RCTs) that compared dressings and/or topical agents with other methods for preventing pressure ulcers. RCTs are medical studies where patients are chosen at random to receive different treatments. This type of trial provides the most reliable evidence. This 
is the first time we have updated this review. We found nine RCTs, giving us a total of 18 relevant trials. These trials included 3629 adults, mainly elderly people, though some included younger adults with mobility-limiting injuries. Products tested included fatty acid (fatty acids come from animal and vegetable fats and oils and are used to moisten the skin), creams and dressings made with silicone or foam.

\section{Key results}

The results of six trials suggest that silicone dressings may reduce the likelihood of people developing pressure ulcers. However, we were uncertain about the evidence from five of these trials because they used poor methods, so we cannot be confident about these results. We also found that use of fatty acid versus a control compound (a cream that does not include fatty acid) may reduce the incidence of pressure ulcers, but results from this trial were uncertain. None of the other comparisons involving topical agents provided conclusive evidence that they make it less likely that people will develop a pressure ulcer.

\section{Quality of the evidence}

The certainty of the evidence in the trials was low to very low. Additional trials at low risk of bias are needed to clarify the effect of dressings and topical agents in preventing pressure ulcers.

We searched for trials that had been published up to March 2017. 


\begin{tabular}{|c|c|c|c|c|c|c|}
\hline \multicolumn{7}{|c|}{$\begin{array}{l}\text { S U M M A R Y O F F I N D I N G S } \\
\text { Summary of findings for the main comparison. Fatty acid versus other topical intervention or standard care for preventing pressure ulcers }\end{array}$} \\
\hline \multicolumn{7}{|c|}{ Fatty acid versus other topical intervention or standard care for preventing pressure ulcers } \\
\hline \multicolumn{7}{|c|}{$\begin{array}{l}\text { Patient or population: individuals at risk of pressure ulcer development } \\
\text { Settings: nursing homes ( } 3 \text { trials); orthopaedic unit (1 trial); high-dependency unit (1 trial) } \\
\text { Intervention: fatty acid } \\
\text { Comparison: other topical intervention or standard care }\end{array}$} \\
\hline \multirow[t]{3}{*}{ Outcomes } & \multicolumn{2}{|c|}{$\begin{array}{l}\text { Illustrative comparative risks* } \\
(95 \% \mathrm{CI})\end{array}$} & \multirow[t]{3}{*}{$\begin{array}{l}\text { Relative effect } \\
(95 \% \mathrm{CI})\end{array}$} & \multirow{3}{*}{$\begin{array}{l}\text { No of partici- } \\
\text { pants } \\
\text { (trials) }\end{array}$} & \multirow{3}{*}{$\begin{array}{l}\text { Quality of the } \\
\text { evidence } \\
\text { (GRADE) }\end{array}$} & \multirow[t]{3}{*}{ Comments } \\
\hline & Assumed risk & $\begin{array}{l}\text { Corresponding } \\
\text { risk }\end{array}$ & & & & \\
\hline & $\begin{array}{l}\text { Other topical } \\
\text { intervention } \\
\text { standard care }\end{array}$ & Fatty acid & & & & \\
\hline \multirow{2}{*}{$\begin{array}{l}\text { Pressure ulcer incidence: } \\
\text { fatty acid vs olive oil As- } \\
\text { sessed with observation } \\
\text { Follow-up: range unknown, } \\
16 \text { weeks }\end{array}$} & \multicolumn{2}{|c|}{ Study population } & \multirow{2}{*}{$\begin{array}{l}\text { RR } 1.28 \\
(0.76 \text { to } 2.17)\end{array}$} & \multirow{2}{*}{$\begin{array}{l}1060 \\
(2 \mathrm{RCTs})\end{array}$} & \multirow{2}{*}{$\begin{array}{l}\oplus \oplus \odot \ominus \\
\text { Low }^{1}\end{array}$} & \multirow{2}{*}{$\begin{array}{l}\text { There was no clear difference in pressure } \\
\text { ulcer incidence }(29 / 511(6 \%) \text { fatty acid, } \\
\text { vs } 24 / 549(4 \%) \text { olive oil; low-certainty evi- } \\
\text { dence) }\end{array}$} \\
\hline & 44 per 1000 & $\begin{array}{l}\mathbf{5 6} \text { per } 1000 \\
\text { (33 to } 95)\end{array}$ & & & & \\
\hline $\begin{array}{l}\text { Pressure ulcer incidence: } \\
\text { fatty acid vs control com- } \\
\text { pound }\end{array}$ & \multicolumn{2}{|c|}{ Study population } & \multirow{3}{*}{$\begin{array}{l}\mathbf{R R} 0.42 \\
(0.22 \text { to } 0.80)\end{array}$} & \multirow{3}{*}{$\begin{array}{l}331 \\
(1 \mathrm{RCT})\end{array}$} & \multirow{3}{*}{$\begin{array}{l}\oplus \oplus \ominus \ominus \\
\text { Low }^{2}\end{array}$} & \multirow{3}{*}{$\begin{array}{l}\text { Fatty acid may reduce pressure ulcer inci- } \\
\text { dence (12/164 (7.3\%) fatty acid, vs } 29 / 167 \\
\text { (17.4\%) control; low-certainty evidence) }\end{array}$} \\
\hline \multirow{2}{*}{\multicolumn{3}{|c|}{$\begin{array}{l}\text { Assessed } \\
\text { with observation } \\
\text { Follow-up: } 30 \text { days }\end{array}$}} & & & & \\
\hline & & & & & & \\
\hline \multirow{2}{*}{$\begin{array}{l}\text { Pressure ulcer incidence: } \\
\text { fatty acid vs standard care } \\
\text { Assessed with observation }\end{array}$} & \multicolumn{2}{|c|}{ Study population } & \multirow{3}{*}{$\begin{array}{l}\text { RR } 0.70 \\
(0.41 \text { to } 1.18)\end{array}$} & \multirow{3}{*}{$\begin{array}{l}187 \\
(2 \mathrm{RCTs})\end{array}$} & \multirow{3}{*}{$\begin{array}{l}\oplus \oplus \ominus \ominus \\
\text { Low }^{3}\end{array}$} & \multirow{3}{*}{$\begin{array}{l}\text { There was no clear difference in pressure } \\
\text { ulcer incidence (18/93 (19\%) fatty acid, vs } \\
26 / 94(28 \%) \text { standard care; low-certainty } \\
\text { evidence) }\end{array}$} \\
\hline & 277 per 1000 & $\begin{array}{l}194 \text { per } 1000 \\
\text { (113 to } 326)\end{array}$ & & & & \\
\hline $\begin{array}{l}\text { Follow-up: range unknown, } \\
30 \text { days }\end{array}$ & & & & & & \\
\hline
\end{tabular}

Patient or population: individuals at risk of pressure ulcer development

Settings: nursing homes ( 3 trials); orthopaedic unit (1 trial); high-dependency unit (1 trial)

Comparison: other topical intervention or standard care 


\begin{tabular}{|c|c|c|c|c|c|c|c|}
\hline \multirow{2}{*}{\multicolumn{2}{|c|}{ 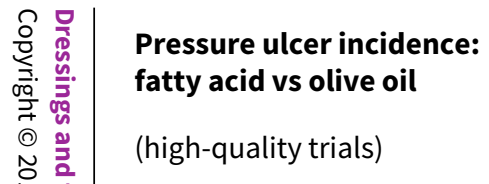 }} & \multicolumn{2}{|c|}{ Study population } & \multirow{2}{*}{$\begin{array}{l}\text { RR } 1.46 \\
\text { (0.77 to } 2.75)\end{array}$} & \multirow{2}{*}{$\begin{array}{l}831 \\
(1 \mathrm{RCT})\end{array}$} & \multirow{2}{*}{$\begin{array}{l}\oplus \oplus \ominus \ominus \\
\text { Low4 }\end{array}$} & \multirow{2}{*}{$\begin{array}{l}\text { There was no clear difference in pressure ul- } \\
\text { cer incidence (fatty acid: } 21 / 394 \text { (5.3\%) fatty } \\
\text { acid, vs } 16 / 437 \text { (3.7\%) olive oil; low-certain- } \\
\text { ty evidence) }\end{array}$} \\
\hline & & 37 per 1000 & $\begin{array}{l}53 \text { per } 1000 \\
(28 \text { to } 101)\end{array}$ & & & & \\
\hline 永 & Adverse event: fatty acid & \multicolumn{2}{|c|}{ Study population } & \multirow{2}{*}{$\begin{array}{l}\text { RR } 2.22 \\
\text { (0.20 to } 24.37 \text { ) }\end{array}$} & \multirow{2}{*}{$\begin{array}{l}831 \\
(1 \mathrm{RCT})\end{array}$} & \multirow{2}{*}{$\begin{array}{l}\oplus \oplus \ominus \ominus \\
\text { Low }^{5}\end{array}$} & \multirow{2}{*}{$\begin{array}{l}\text { There was no clear difference in adverse } \\
\text { events (itching or redness); (fatty acid } 2 / 294 \\
(0.007 \%) \text {, vs } 1 / 437(0.002 \%) \text { olive oil; low- } \\
\text { certainty evidence) }\end{array}$} \\
\hline 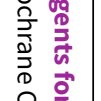 & & 2 per 1000 & $\begin{array}{l}\mathbf{5} \text { per } \mathbf{1 0 0 0} \\
(0 \text { to } 56)\end{array}$ & & & & \\
\hline
\end{tabular}

${ }^{\star}$ The basis for the assumed risk (e.g. the median control group risk across trials) is provided in footnotes. The corresponding risk (and its $95 \%$ confidence interval) is based on the assumed risk in the comparison group and the relative effect of the intervention (and its $95 \% \mathrm{Cl}$ ).

CI: confidence interval; $\mathbf{R C T}$ : randomised controlled trial; RR: risk ratio

\section{GRADE Working Group grades of evidence}

High certainty: we are very confident that the true effect lies close to that of the estimate of the effect.

Moderate certainty: we are moderately confident in the effect estimate: the true effect is likely to be close to the estimate of the effect, but there is a possibility that it is substantially different.

Low certainty: our confidence in the effect estimate is limited: the true effect may be substantially different from the estimate of the effect.

Very low certainty: we have very little confidence in the effect estimate: the true effect is likely to be substantially different from the estimate of effect.

1Downgraded twice for imprecision due to the small number of events and the wide confidence interval.

2Downgraded once for high risk for attrition bias and downgraded once for serious imprecision due to the small number of events.

${ }^{3}$ Downgraded once for high risk of performance bias and downgraded once for serious imprecision due to a wide confidence interval.

${ }^{4}$ Downgraded twice for imprecision due small number of events leading to a wide confidence interval.

5 Downgraded twice for very serious imprecision due to a very wide confidence interval and very small number of events.

\section{Summary of findings 2. Active topical agent versus placebo/control for preventing pressure ulcers}

\section{Active topical agent versus placebo/control for preventing pressure ulcers}

Patient or population: individuals at risk of pressure ulcer development

Settings: nursing homes (1 trial); geriatric medicine (3 trials)

Intervention: active topical agent

Comparison: placebo/control

\begin{tabular}{|c|c|c|c|c|c|c|}
\hline \multirow[t]{2}{*}{ Outcomes } & \multicolumn{2}{|c|}{$\begin{array}{l}\text { Illustrative comparative risks* } \\
(95 \% \mathrm{Cl})\end{array}$} & \multirow[t]{2}{*}{$\begin{array}{l}\text { Relative effect } \\
(95 \% \mathrm{Cl})\end{array}$} & \multirow{2}{*}{$\begin{array}{l}\text { No of partici- } \\
\text { pants } \\
\text { (trials) }\end{array}$} & \multirow{2}{*}{$\begin{array}{l}\text { Quality of the } \\
\text { evidence } \\
\text { (GRADE) }\end{array}$} & \multirow[t]{2}{*}{ Comments } \\
\hline & Assumed risk & $\begin{array}{l}\text { Corresponding } \\
\text { risk }\end{array}$ & & & & \\
\hline
\end{tabular}




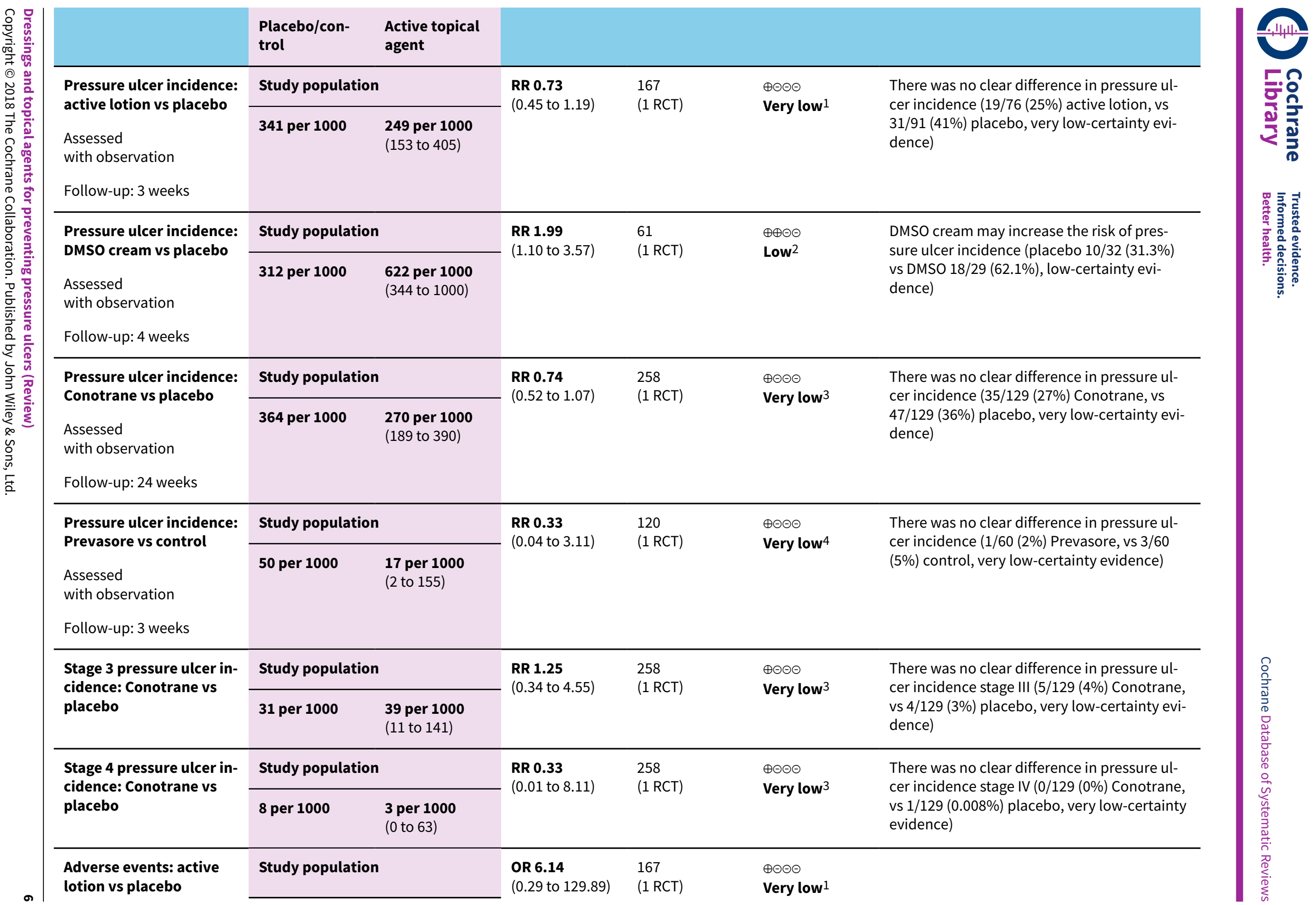


${ }^{*}$ The basis for the assumed risk (e.g. the median control group risk across trials) is provided in footnotes. The corresponding risk (and its $95 \%$ confidence interval) is based on the assumed risk in the comparison group and the relative effect of the intervention (and its $95 \% \mathrm{Cl}$ ).

Cl: confidence interval; $\mathbf{R C T}$ : randomised controlled trial; $\mathbf{R R}$ : risk ratio; OR: odds ratio

\section{GRADE Working Group grades of evidence}

High certainty: we are very confident that the true effect lies close to that of the estimate of the effect.

Moderate certainty: we are moderately confident in the effect estimate: the true effect is likely to be close to the estimate of the effect, but there is a possibility that it is substantially different.

Low certainty: our confidence in the effect estimate is limited: the true effect may be substantially different from the estimate of the effect.

Very low certainty: we have very little confidence in the effect estimate: the true effect is likely to be substantially different from the estimate of effect.

1Downgraded twice for risk of bias due to high risk of attrition bias and unclear risk of selection bias and downgraded once for serious imprecision due to a wide confidence interval. 2 Downgraded once for unclear risk of selection bias and downgraded once for imprecision due to a wide confidence interval.

3Downgraded twice for risk of bias due to selection bias and other bias due to baseline imbalance; and downgraded once for serious imprecision due to a wide confidence interval.

${ }^{4}$ Downgraded twice for risk of bias due to selection bias and other bias due to manufacturer involvement in one trial and baseline imbalance; and downgraded twice for very serious imprecision due to a wide confidence interval.

\section{Summary of findings 3 . Silicone dressing compared with no dressing for preventing pressure ulcers}

Silicone dressing compared with no dressing for preventing pressure ulcers

Patient or population: individuals at risk of pressure ulcer development

Setting: intensive care unit (4 trials); medical/surgical units (2 trials)

Intervention: silicone dressing

Comparison: no dressing

\begin{tabular}{|c|c|c|c|c|c|c|}
\hline \multirow[t]{2}{*}{ Outcomes } & \multicolumn{2}{|c|}{$\begin{array}{l}\text { Anticipated absolute effects } \\
(95 \% \mathrm{Cl})\end{array}$} & \multirow[t]{2}{*}{$\begin{array}{l}\text { Relative effect } \\
(95 \% \mathrm{Cl})\end{array}$} & \multirow{2}{*}{$\begin{array}{l}\text { № of partici- } \\
\text { pants } \\
\text { (trials) }\end{array}$} & \multirow{2}{*}{$\begin{array}{l}\text { Quality of the } \\
\text { evidence } \\
\text { (GRADE) }\end{array}$} & \multirow[t]{2}{*}{ Comments } \\
\hline & $\begin{array}{l}\text { Risk with no } \\
\text { dressing }\end{array}$ & $\begin{array}{l}\text { Risk with Sili- } \\
\text { cone dressing }\end{array}$ & & & & \\
\hline Pressure ulcer & \multicolumn{2}{|c|}{ Study population } & \multirow{2}{*}{$\begin{array}{l}\text { RR } \mathbf{0 . 2 5} \\
\text { (0.16 to } 0.41 \text { ) }\end{array}$} & \multirow{2}{*}{$\begin{array}{l}1247 \\
\text { (6 RCTs) }\end{array}$} & \multirow{2}{*}{$\begin{array}{l}\oplus \oplus \ominus \ominus \\
\text { Low }^{1}\end{array}$} & \multirow{2}{*}{$\begin{array}{l}\text { Silicone dressings may reduce pressure ulcer inci- } \\
\text { dence (any stage) (silicone } 18 / 632 \text { (3\%); no dressing } \\
\text { 72/615, (11.7\%), low-certainty evidence) }\end{array}$} \\
\hline Assessed & 117 per 1000 & $\begin{array}{l}29 \text { per } 1000 \\
\text { (19 to } 48)\end{array}$ & & & & \\
\hline
\end{tabular}




\begin{tabular}{|c|c|c|c|c|c|c|}
\hline \multicolumn{7}{|c|}{ 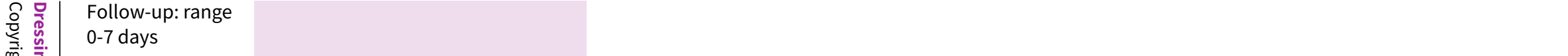 } \\
\hline \multirow{2}{*}{$\begin{array}{l}\text { Stage } 1 \text { pressure } \\
\text { ulcer incidence }\end{array}$} & \multicolumn{2}{|c|}{ Study population } & \multirow{2}{*}{$\begin{array}{l}\text { RR } \mathbf{0 . 2 7} \\
(0.08 \text { to } 0.90)\end{array}$} & \multirow{2}{*}{$\begin{array}{l}749 \\
\text { (3 RCTs) }\end{array}$} & \multirow{2}{*}{$\begin{array}{l}\oplus \ominus \ominus \ominus \\
\text { Very low } 2\end{array}$} & \multirow{2}{*}{$\begin{array}{l}\text { It is unclear whether silicone dressings reduce the inci- } \\
\text { dence of stage } 1 \text { pressure ulcers (silicone } 8 / 377(2 \%) \text {; } \\
\text { no dressing } 35 / 372(9 \%) \text {; very low-certainty evidence). }\end{array}$} \\
\hline & 94 per 1000 & $\begin{array}{l}25 \text { per } 1000 \\
(8 \text { to } 85)\end{array}$ & & & & \\
\hline \multirow{2}{*}{$\begin{array}{l}\text { Stage } 2 \text { pressure } \\
\text { ulcer incidence }\end{array}$} & \multicolumn{2}{|c|}{ Study population } & \multirow{2}{*}{$\begin{array}{l}\text { RR } 0.40 \\
(0.17 \text { to } 0.94)\end{array}$} & \multirow{2}{*}{$\begin{array}{l}1090 \\
\text { (4 RCTs) }\end{array}$} & \multirow{2}{*}{$\begin{array}{l}\oplus \odot \odot \ominus \\
\text { Very low } 3\end{array}$} & \multirow{2}{*}{$\begin{array}{l}\text { It is unclear whether silicone dressings reduce the in- } \\
\text { cidence of stage } 2 \text { pressure ulcers, compared with no } \\
\text { dressing (silicone } 2 \%, 9 / 548 \text {, no dressing } 5 \%, 26 / 542 \text {; } \\
\text { very low-certainty evidence) }\end{array}$} \\
\hline & 48 per 1000 & $\begin{array}{l}19 \text { per } 1000 \\
(8 \text { to } 45)\end{array}$ & & & & \\
\hline \multirow{2}{*}{$\begin{array}{l}\text { Stage } 4 \text { pressure } \\
\text { ulcer incidence }\end{array}$} & \multicolumn{2}{|c|}{ Study population } & \multirow{2}{*}{$\begin{array}{l}\text { RR } 0.20 \\
(0.01 \text { to } 4.13)\end{array}$} & \multirow{2}{*}{$\begin{array}{l}322 \\
(1 \mathrm{RCT})\end{array}$} & \multirow{2}{*}{$\begin{array}{l}\oplus \odot \odot \ominus \\
\text { Very low } 4\end{array}$} & \multirow{2}{*}{$\begin{array}{l}\text { There was no clear difference in stage } 4 \text { pressure ulcer } \\
\text { incidence (silicone } 0 / 161(0 \%) \text {; no dressing 2/161 (1\%), } \\
\text { very low-certainty evidence) }\end{array}$} \\
\hline & 12 per 1000 & $\begin{array}{l}2 \text { per } 1000 \\
(0 \text { to } 51)\end{array}$ & & & & \\
\hline \multirow{2}{*}{$\begin{array}{l}\text { Unstageable } \\
\text { pressure ulcer } \\
\text { incidence }\end{array}$} & & & \multirow{2}{*}{$\begin{array}{l}\text { RR } 0.20 \\
(0.01 \text { to } 4.09)\end{array}$} & \multirow{2}{*}{$\begin{array}{l}366 \\
(1 \mathrm{RCT})\end{array}$} & \multirow{2}{*}{$\begin{array}{l}\oplus \ominus \odot \odot \\
\text { Very low } 5\end{array}$} & \multirow{2}{*}{$\begin{array}{l}\text { There was no clear difference in unstageable pressure } \\
\text { ulcer incidence (silicone } 0 / 184 \text { (0\%); no dressing } 2 / 182 \\
(1 \%) \text {, very low-certainty evidence) }\end{array}$} \\
\hline & 11 per 1000 & $\begin{array}{l}2 \text { per } 1000 \\
(0 \text { to } 45)\end{array}$ & & & & \\
\hline \multirow{2}{*}{$\begin{array}{l}\text { Deep tissue in- } \\
\text { jury pressure ul- } \\
\text { cer incidence }\end{array}$} & & & \multirow{2}{*}{$\begin{array}{l}\text { RR } 0.99 \\
(0.06 \text { to } 15.69)\end{array}$} & \multirow{2}{*}{$\begin{array}{l}366 \\
(1 \mathrm{RCT})\end{array}$} & \multirow{2}{*}{$\begin{array}{l}\oplus \odot \odot \ominus \\
\text { Very low } 6\end{array}$} & \multirow{2}{*}{$\begin{array}{l}\text { There was no clear difference in deep tissue injury } \\
\text { pressure ulcer incidence (silicone } 1 / 184(0.005 \%) ; \text { no } \\
\text { dressing } 1 / 182(0.005 \%) \text {, very low-certainty evidence) }\end{array}$} \\
\hline & 5 per 1000 & $\begin{array}{l}\mathbf{5} \text { per } \mathbf{1 0 0 0} \\
(0 \text { to } 86)\end{array}$ & & & & \\
\hline Adverse events & None repor & & & & & \\
\hline
\end{tabular}

${ }^{\star}$ The risk in the intervention group (and its $95 \%$ confidence interval) is based on the mean risk in the comparison group and the relative effect of the intervention (and its $95 \% \mathrm{Cl})$.

Cl: confidence interval; $\mathbf{R C T}$ : randomised controlled trial; RR: risk ratio

\section{GRADE Working Group grades of evidence}

High certainty: we are very confident that the true effect lies close to that of the estimate of the effect.

Moderate certainty: we are moderately confident in the effect estimate: the true effect is likely to be close to the estimate of the effect, but there is a possibility that it is substantially different.

Low certainty: our confidence in the effect estimate is limited: the true effect may be substantially different from the estimate of the effect.

Very low certainty: we have very little confidence in the effect estimate: the true effect is likely to be substantially different from the estimate of effect. 


\begin{tabular}{|c|c|c|c|c|c|c|}
\hline \multicolumn{7}{|c|}{$\begin{array}{l}2 \text { Downgraded twice for high or unclear risk of bias for multiple criteria, specifically selection and detection bias and downgraded twice for serious imprecision due to wide } \\
\text { confidence interval. } \\
3 \text { Downgraded twice for high or unclear risk of bias for multiple criteria, specifically selection and detection bias and downgraded twice for very serious imprecision due to very } \\
\text { few events and very wide confidence interval. } \\
4 \text { Downgraded twice for high or unclear risk of bias for multiple criteria, specifically selection and detection bias and downgraded twice for very serious imprecision due to very } \\
\text { few events and very wide confidence interval. } \\
5 \text { Downgraded twice for high or unclear risk of bias for multiple criteria, specifically selection and detection bias and downgraded twice for very serious imprecision due to very } \\
\text { few events and very wide confidence interval. } \\
6 \text { Downgraded twice for high or unclear risk of bias for multiple criteria, specifically selection and detection bias and downgraded twice for very serious imprecision due to very } \\
\text { few events and very wide confidence interval. }\end{array}$} \\
\hline \multicolumn{7}{|c|}{ Other dressing versus control for preventing pressure ulcers } \\
\hline \multicolumn{7}{|c|}{$\begin{array}{l}\text { Patient or population: individuals at risk of pressure ulcer development } \\
\text { Settings: intensive care, coronary care and medical clinic ( } 2 \text { trials); spinal surgery (1 trial); geriatric hospital (1 trial) } \\
\text { Intervention: other dressing } \\
\text { Comparison: control }\end{array}$} \\
\hline \multirow[t]{3}{*}{ Outcomes } & \multicolumn{2}{|c|}{$\begin{array}{l}\text { Illustrative comparative risks* } \\
(95 \% \mathrm{CI})\end{array}$} & \multirow[t]{3}{*}{$\begin{array}{l}\text { Relative effect } \\
(95 \% \mathrm{Cl})\end{array}$} & \multirow[t]{3}{*}{$\begin{array}{l}\text { No of partici- } \\
\text { pants } \\
\text { (trials) }\end{array}$} & \multirow[t]{3}{*}{$\begin{array}{l}\text { Quality of the } \\
\text { evidence } \\
\text { (GRADE) }\end{array}$} & \multirow[t]{3}{*}{ Comments } \\
\hline & Assumed risl & $\begin{array}{l}\text { Corresponding } \\
\text { risk }\end{array}$ & & & & \\
\hline & Control & Other dressing & & & & \\
\hline $\begin{array}{l}\text { Pressure ulcer incidence: } \\
\text { polyurethane film vs hydro- } \\
\text { colloid dressing }\end{array}$ & \multicolumn{2}{|c|}{ Study population } & \multirow[t]{2}{*}{$\begin{array}{l}\mathbf{R R} \mathbf{0 . 5 8} \\
(0.24 \text { to } 1.41)\end{array}$} & \multirow[t]{2}{*}{$\begin{array}{l}160 \\
(1 \mathrm{RCT})\end{array}$} & \multirow[t]{2}{*}{$\begin{array}{l}\oplus \ominus \ominus \ominus \\
\text { Very low } 1\end{array}$} & \multirow{2}{*}{$\begin{array}{l}\text { There was no clear difference in pres- } \\
\text { sure ulcer incidence (polyurethane film } \\
7 / 80(9 \%) \text {; hydrocolloid } 12 / 80 \text { (15\%), } \\
\text { very low-certainty evidence) }\end{array}$} \\
\hline $\begin{array}{l}\text { colloid dressing } \\
\text { Assessed with observation } \\
\text { Follow-up: } 30 \text { days }\end{array}$ & 150 per 1000 & $\begin{array}{l}\mathbf{8 7} \text { per } \mathbf{1 0 0 0} \\
\text { (36 to } 211)\end{array}$ & & & & \\
\hline \multirow[t]{2}{*}{$\begin{array}{l}\text { Pressure ulcer incidence: } \\
\text { Kang' huier vs routine care }\end{array}$} & \multicolumn{2}{|c|}{ Study population } & \multirow{2}{*}{$\begin{array}{l}\text { RR } 0.42 \\
(0.08 \text { to } 2.05)\end{array}$} & \multirow{2}{*}{$\begin{array}{l}100 \\
(1 \mathrm{RCT})\end{array}$} & \multirow{2}{*}{$\begin{array}{l}\oplus \ominus \ominus \ominus \\
\text { Very low } 2\end{array}$} & \multirow{2}{*}{$\begin{array}{l}\text { There was no clear difference in pres- } \\
\text { sure ulcer incidence (Kang' huier } 2 / 49 \\
\text { (4\%); routine care } 5 / 51(10 \%) \text {, very low- } \\
\text { certainty evidence) }\end{array}$} \\
\hline & 98 per 1000 & $\begin{array}{l}41 \text { per } 1000 \\
(8 \text { to } 201)\end{array}$ & & & & \\
\hline
\end{tabular}




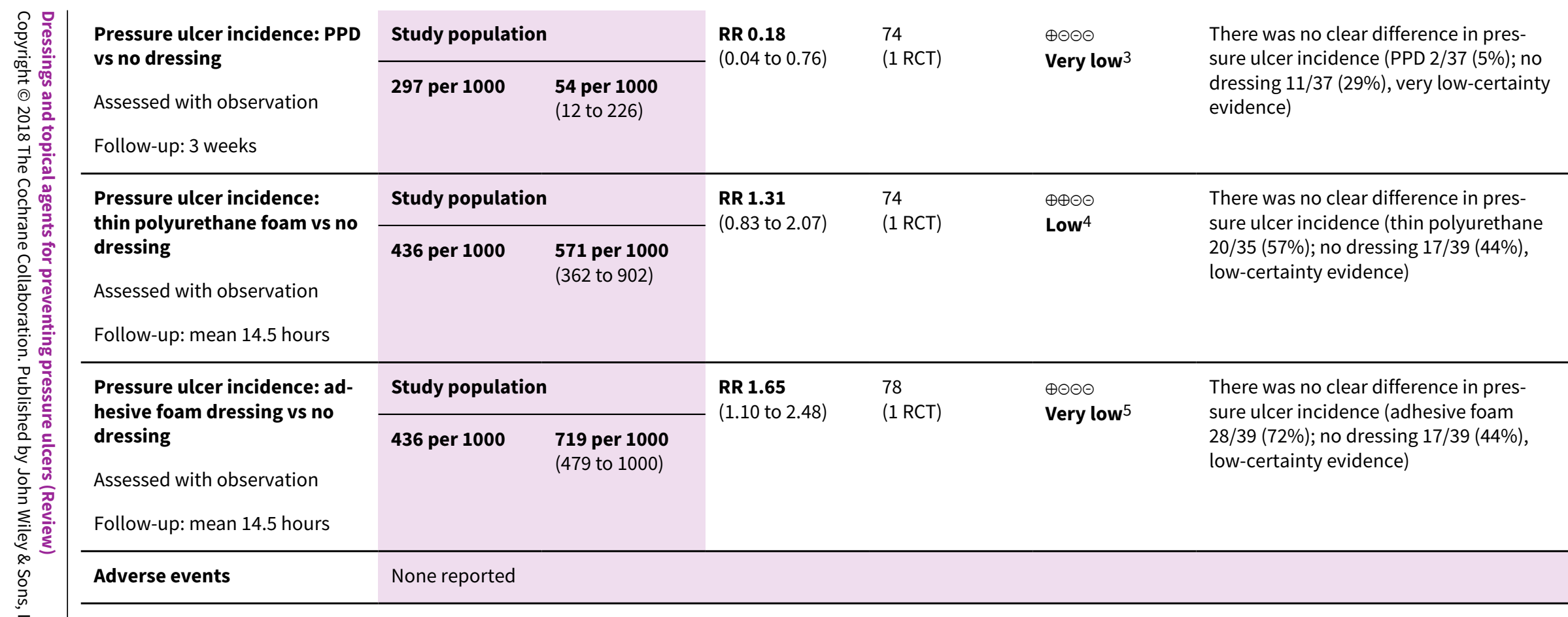

*The basis for the assumed risk (e.g. the median control group risk across trials) is provided in footnotes. The corresponding risk (and its $95 \%$ confidence interval) is based on the assumed risk in the comparison group and the relative effect of the intervention (and its $95 \% \mathrm{Cl}$ ).

Cl: confidence interval; PPD: pressure ulcer preventive dressing; RCT: randomised controlled trial; RR: risk ratio

\section{GRADE Working Group grades of evidence}

High certainty: we are very confident that the true effect lies close to that of the estimate of the effect.

Moderate certainty: we are moderately confident in the effect estimate: the true effect is likely to be close to the estimate of the effect, but there is a possibility that it is substantially different.

Low certainty: our confidence in the effect estimate is limited: the true effect may be substantially different from the estimate of the effect.

Very low certainty: we have very little confidence in the effect estimate: the true effect is likely to be substantially different from the estimate of effect.

1Downgraded once due to high risk of performance bias, and downgraded twice for serious imprecision due to small number of events and wide confidence interval.

2Downgraded twice for risk of bias due to high risk of performance and detection bias, and downgraded twice for serious imprecision due to small number of events and wide confidence interval.

3 Downgraded twice for risk of bias due to high risk of performance, detection and other bias, and downgraded twice for serious imprecision due to small number of events and wide confidence interval.

4 Downgraded twice for risk of bias due to high risk of performance and attrition bias, and downgraded once for imprecision due to a wide confidence interval.

5 Downgraded twice for risk of bias due to high risk of performance and attrition bias, and downgraded once for imprecision due to a wide confidence interval. 


\section{B A C K G R O U N D}

\section{Description of the condition}

A pressure ulcer is defined as localised injury to the skin, underlying tissue or both, usually over a bony prominence, as a result of pressure, or pressure in combination with shear. A number of contributing or confounding factors are also associated with pressure ulcers; the significance of these factors has yet to be elucidated (NPUAP/EPUAP/PPPIA 2014). Point prevalence rates range from 7\% to 53.2\% (Guest 2015; Moore 2012; Moore 2013b). Pressure ulcers are generally staged 1, 2, 3 and 4, according to the depth of tissue damage, with stage 1 being the least severe and stage 4 indicating full-scale tissue destruction (NPUAP/EPUAP/ PPPIA 2014; Appendix 1). The most common anatomical sites for pressure ulcers to occur are the sacrum and the heels, and the majority are stage 1 or stage 2 in severity (Jenkins 2010; Moore 2011b; Moore 2013b).

The exact mechanisms by which externally applied mechanical forces (pressure and shear) result in pressure ulcer development are not clearly understood (Stekelenburg 2007). Pressure is equal to force divided by area, the same amount of force applied to a small area, when compared with a bigger area, will result in greater pressure (O'Callaghan 2007). Shear is the mechanical stress acting parallel to a plane of interest, such as is seen when a person sits up in bed and then begins to slide down the bed, with their skin remaining in the same place because it sticks to the bed linen (Collier 2006). It is postulated that, in the presence of prolonged pressure and shear forces, there are four mechanisms within three functional units that lead to pressure ulcer development. The functional units are the capillaries, the interstitial (between cells) spaces and the cells (Nixon 2005). The mechanisms are local ischaemia (lack of oxygen) (Kosiak 1959), reperfusion injury (injury to cells caused by the restoration of blood supply to tissues) (Tsuji 2005), impaired interstitial fluid flow, and lymphatic drainage (Reddy 1981) and sustained deformity of cells (Bader 1990; Stekelenburg 2007). These mechanisms, alone or combined, reduce the oxygen and nutrient supply to cells, impair the removal of waste products following cell metabolism, leading to cell damage and inevitable tissue destruction. It is important to note, however, that none of the processes described will have any relevance unless the individual is exposed to sustained external mechanical forces. Therefore, as pressure/shear are the causative factors, reducing the amount and duration of pressure/shear will decrease the likelihood of pressure ulcer development (Oomens 2015).

Pressure ulcers occur in people who do not have the ability to reposition themselves in order to relieve pressure on bony prominences. This ability is often diminished in the very old, the malnourished and those with an acute illness (Wann-Hansson 2008). It is important to note, however, that although pressure ulcers occur most commonly in older individuals, other populations are also at risk. People with spinal cord injuries and hospital patients who have poor blood supply to the limbs or who undergo prolonged periods of immobility (for example during long surgical procedures) also have high pressure ulcer incidence (Gallagher 2008; Sheerin 2005). The heel is particularly vulnerable to pressure ulcer development, given its anatomical shape, which is curved and sharp (Gefen 2017). As a result, tissues in the heel become highly distorted, stretched, compressed and sheared, making pressure ulcer development highly likely unless prevention strategies are quickly employed (Gefen 2017). Certain people, with stage 1 pressure ulcers, are also at increased risk of the pressure ulcer progressing to a stage 4 (Vanderwee 2009). For example, individuals with hypotension, contractures, or a history of cerebral vascular accident, tend to develop more serious pressure ulcers despite standard preventive measures (Vanderwee 2009). Thus, a clear focus on the adoption of targeted prevention strategies is important at the outset, so that the individual is not exposed to pressure ulcers in the first instance (Sullivan 2013; Vanderwee 2009).

Pressure ulcers have a negative impact on an individual's quality of life. Indeed, the emotional, physical, mental and social domains of life are all profoundly affected (Gorecki 2012; Spilsbury 2007). Pain is described as one of the most significant problems for individuals with pressure ulcers (Gorecki 2012; Spilsbury 2007). Importantly, many of the treatment regimens adopted exacerbate these adverse effects (Hopkins 2006). Thus, it is important to consider the impact of prevention and treatment strategies on the individual, and to choose those that will reduce discomfort and enhance rehabilitation wherever possible (Gorecki 2009). Pressure ulcers are also associated with increased mortality (Kröger 2008). Whether this relates to the fact that pressure ulcers occur in a population that is for the most part debilitated, with a high incidence of co-morbidities, or whether it relates to the presence of a pressure ulcer alone, remains unclear (Brown 2003; Tarnowski Goodell 2013; Thomas 1996). None the less, a recent trial found a mortality of $66 \%$ among people with pressure ulcers, over a median 12-week follow-up period (Khor 2014).

Pressure ulcers impose a significant financial burden on healthcare systems. Dealey 2012 suggests that the total annual cost for pressure ulcer management in the UK is GBP 1.4 to 2.1 billion annually, or $4 \%$ of the total UK healthcare expenditure. In Australia, the mean hospital costs for pressure ulcers are estimated at AUD 296.05 million (Graves 2005). In the USA, hospital costs for adults with a diagnosis of pressure ulcers totaled USD 11.0 billion in 2006 (Russo 2006). That pressure ulcers are an expensive problem has also been reported in the Netherlands, where they have been found to be the third most costly issue for healthcare services. (Haalboom 2000). This is not due to the cost of medication or surgical interventions, but due to prolonged hospitalisation and the intensive nursing care required. Furthermore, costs will differ, depending on the geographical and clinical setting. A recent trial found that the cost of pressure ulcer treatment per patient per day ranged from EUR 1.71 to EUR 470.49 across different clinical settings (Demarre 2015).

\section{Description of the intervention}

Pressure ulcer prevention can involve a range of interventions, such as nutritional care (Langer 2003), skin care, use of pressure redistribution surfaces (McInnes 2011), and repositioning (Moore 2011b). Selection of an appropriate topical therapy (i.e. those applied to the skin) is also believed to contribute to pressure ulcer prevention strategies, and such therapies are widely used within the clinical setting (NPUAP/EPUAP/PPPIA 2014), in combination with other preventive strategies.

A topical agent is a cream or an ointment that is applied directly to the skin (Reddy 2006). Whereas a dressing is a therapeutic or protective material applied to a wound to promote healing, it may also be used to protect the skin from damage (Butcher 
2009). Dressings are classified into groups depending on their characteristics (Moore 2006).

For the purposes of pressure ulcer prevention, the types of dressings used are primarily those that afford protection to the skin, such as:

- semi-permeable film dressings (a thin polyurethane membrane coated with a layer of an acrylic adhesive);

- hydrocolloid dressings (a dressing containing a dispersion of gelatin, pectin and carboxy-methylcellulose together with other polymers and adhesives forming a flexible wafer);

- foam dressings (an open cell, hydrophobic, polyurethane foam sheet; Surgical Materials Testing Lab 2007);

- multilayer foam dressings with silicone (dressing coated with soft silicone as an adhesive or a wound contact layer; Meuleneire 2013).

Topical agents may be used in isolation, but are more likely to be impregnated in dressings, or used in combination with dressings.

\section{How the intervention might work}

One hypothesis upon which the use of dressings/topical agents for the prevention of pressure ulcers is based, relates to their role in the reduction of friction forces (Butcher 2009). Furthermore, Lahmann 2011 identified friction as a causative factor in the development of superficial wounds resembling stage 1 and 2 pressure ulcers, whereas, pressure and shear were responsible for the development of deeper ulcers (stages 3 and 4). Earlier work by Kottner 2009 supports this argument, in classifying ulcers as superficial predominantly caused by friction, or deep - predominantly caused by pressure. Therefore, dressings that reduce frictional forces may play a role in pressure ulcer prevention (International Review 2010; Levy 2015).The NPUAP/EPUAP/PPPIA 2014 guidelines suggest that use of film dressings may help to protect the skin against the adverse effects of friction. Furthermore, they suggest that use of foam dressings may protect parts of the body at risk of shear injury. It has also been suggested that the application of topical agents directly to the skin will protect against the adverse affects of friction (Reddy 2006). In addition to the impact of friction, more recent work of Call 2015 suggests that dressings may also play a role in reducing shear forces at the superficial layers of the tissues. They suggest that this occurs through a number of processes which either enable absorption or displacement of the shear forces. The ability to facilitate these processes will depend on the nature of the dressing, that is, a certain amount of bulk is needed for absorption and displacement of the shear forces. Furthermore, others have also noted that dressings may dissipate tissue strain, by promoting internal shear in the dressing, which diverts loads from tissues (Levy 2015).

\section{Why it is important to do this review}

The use of dressings for preventing pressure ulcers is discussed in the literature and in international pressure ulcer prevention guidelines. Prior to the publication of the original version of this review (Moore 2013a), the level of evidence to support these recommendations had not been systematically assessed (Butcher 2009). The use of adjunct therapies (for example, dressings, creams, or lotions) as part of prevention strategies adds to the overall costs, therefore it is important to explore whether use of these therapies provides potential benefit to patients (Moore 2008). This is the first update of this review.

\section{O B J E C T IVES}

To evaluate the effects of dressings and topical agents on pressure ulcer prevention, in people of any age without existing pressure ulcers, but considered to be at risk of developing a pressure ulcer, in any healthcare setting.

\section{METHODS}

\section{Criteria for considering studies for this review}

\section{Types of studies}

Trials that randomised individuals (randomised controlled trials (RCTs)) or that randomised by groups (cluster-RCTs), were eligible for inclusion.

\section{Types of participants}

People of any age, both adults and children, without a pressure ulcer, but considered to be at risk of developing a pressure ulcer, in any care setting.

\section{Types of interventions}

The primary intervention was any wound dressing or topical agent applied to the skin at any frequency with the aim of preventing the development of a pressure ulcer. We included RCTs comparing the use of dressings, topical agents, or topical agents with dressings, compared with a different dressing, topical agent, combined topical agent and dressing, no intervention or standard care or any other intervention.

\section{Types of outcome measures}

\section{Primary outcomes}

Pressure ulcer incidence (the proportion of people developing any new pressure ulcer(s) of any stage). For the purpose of this review, we defined a pressure ulcer as a localised injury to the skin, underlying tissue or both, usually over a bony prominence, as a result of pressure, or pressure in combination with shear. This review included all stages of pressure ulcer damage, following the definition of the NPUAP/EPUAP/PPPIA 2014. We accepted the definition of the method of assessment of pressure ulcer damage as outlined by trial authors.

\section{Secondary outcomes}

- Stage of any new pressure ulcer(s)

- Time to ulcer development

- Costs of interventions

- Quality of life, measured by a validated scale

- Pain at dressing change, measured using a validated scale

- Acceptability of the intervention (or satisfaction) with respect to patient comfort

- Adverse events

- Length of hospital stay 


\section{Search methods for identification of studies}

\section{Electronic searches}

In March 2017, for this first update, we searched the following electronic databases for RCTs or cluster-RCTs that evaluated the use of dressings or topical agents for the prevention of pressure ulcers:

- the Cochrane Wounds Specialised Register (searched 20 March 2017);

- the Cochrane Central Register of Controlled Trials (CENTRAL; 2018, Issue 4) in the Cochrane Library (searched 20 March 2017);

- Ovid MEDLINE including In-Process \& Other Non-Indexed Citations (1946 to 20 March 2017);

- Ovid Embase (1974 to 20 March 2017);

- EBSCO CINAHL Plus (Cumulative Index to Nursing and Allied Health Literature; 1937 to 20 March 2017).

The search strategy we used to search CENTRAL can be found in Appendix 2. The search strategies for Ovid MEDLINE, Ovid Embase and EBSCO CINAHL Plus can be found in Appendix 3. We combined the Ovid MEDLINE search with the Cochrane Highly Sensitive Search Strategy for identifying randomised trials in MEDLINE: sensitivity- and precision-maximising version (2008 revision) (Lefebvre 2011). We combined the Embase search with the Ovid Embase filter developed by the UK Cochrane Centre (Lefebvre 2011). We combined the CINAHL searches with the trial filters developed by the Scottish Intercollegiate Guidelines Network (SIGN 2017). There were no restrictions with respect to language, date of publication or trial setting .

We searched the following clinical trials registries on 30 March 2017:
- ClinicalTrials.gov (www.clinicaltrials.gov);

- World Health Organization (WHO) International Clinical Trials Registry Platform (www.who.int/trialsearch).

We performed further searches in May 2018. Those results have been added to Studies awaiting classification and will be incorporated into the review at the next update.

\section{Searching other resources}

We searched the bibliographies of all retrieved and relevant publications identified for further trials. We contacted manufacturers of dressings $(n=15)$ used in the prevention of pressure ulcers, as identified in the British National Formulary (BNF 2017), and experts in the field to ask for information relevant to this review.

\section{Data collection and analysis}

We carried out data collection and analysis according to methods stated in the published protocol (Moore 2011a), which were based on the Cochrane Handbook for Systematic Reviews of Interventions (Higgins 2011a).

\section{Selection of studies}

Two review authors independently assessed titles and, where available, abstracts of the trials identified by the search strategy against the eligibility criteria for inclusion in the review. We obtained full versions of potentially relevant trials and the two review authors independently screened these against the inclusion criteria. Any differences in opinion were resolved by discussion and, where necessary, reference to Cochrane Wounds editorial base. We completed a PRISMA flowchart to summarise this process (Liberati 2009; Figure 1). 
Figure 1. Study flow diagram

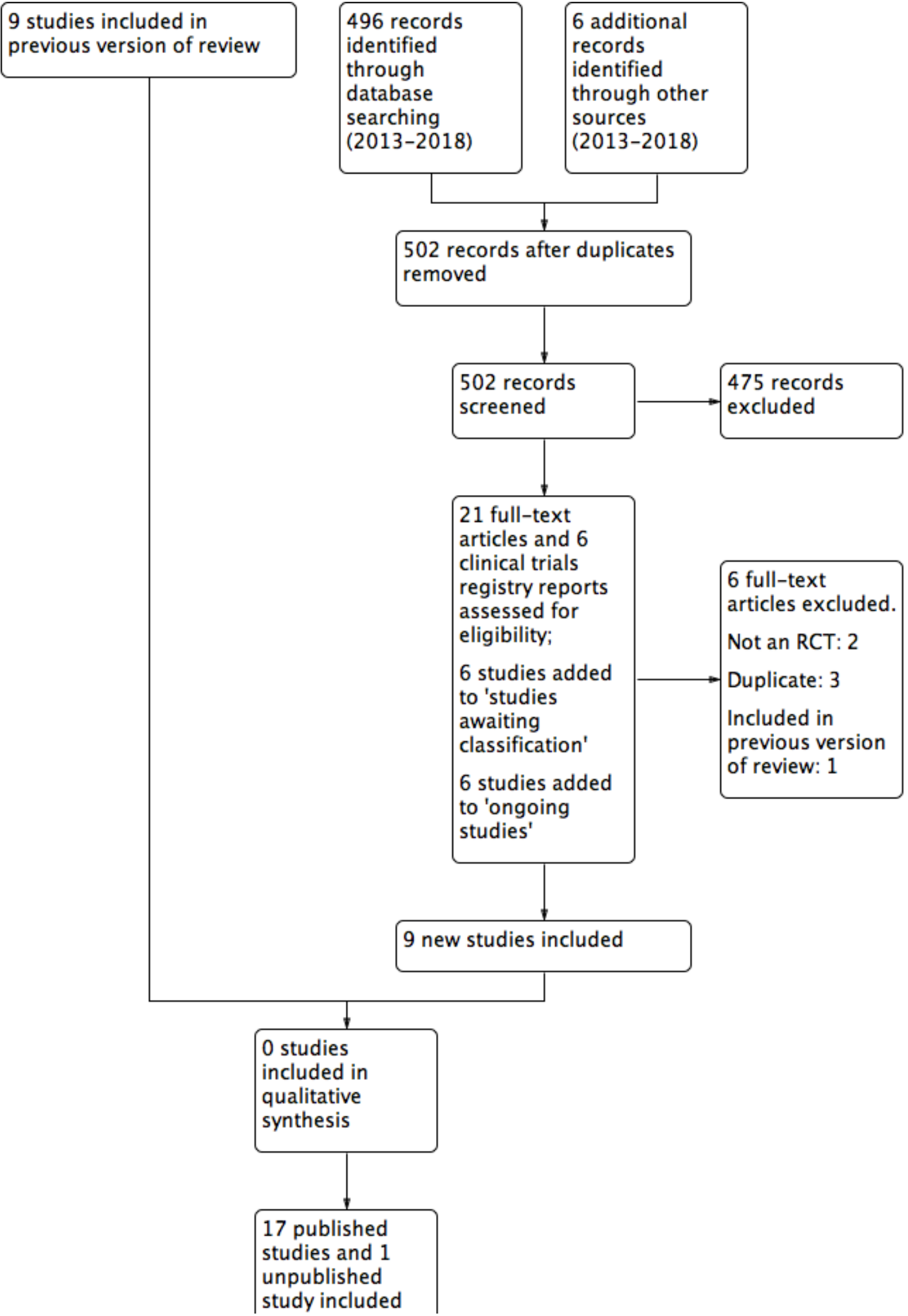


Figure 1. (Continued)

unpublısned
study included
in quantitative
synthesis
(meta-analysis)
18 trials in total

\section{Data extraction and management}

Two review authors independently extracted data from eligible trials using a data extraction sheet. Specifically, we extracted the following information:

- author, title, source;

- date of trial, trial's geographical location;

- funding source;

- care setting;

- inclusion/exclusion criteria;

- participant characteristics;

- balance of groups at baseline;

- trial design details;

- method of randomisation;

- allocation concealment;

- sample size calculation and sample size;

- intervention details, concurrent interventions;

- type of dressing and frequency of dressing change;

- use of additional dressing materials;

- participant length of hospital stay;

- outcome measures;

- blinding (of the participant/outcome assessor);

- length of follow-up;

- loss to follow-up;

- results;

- intention-to-treat analysis; and

- conclusions as reported by the trial authors.

We resolved any differences in opinion by discussion and, where necessary, with reference to Cochrane Wounds editorial base. If data were missing from reports, we attempted to contact trial authors to obtain the missing information.

\section{Assessment of risk of bias in included studies}

Two review authors independently assessed the included trials using the Cochrane tool for assessing risk of bias (Higgins 2011b). This tool addresses six specific domains: namely, sequence generation, allocation concealment, blinding, incomplete outcome data, selective outcome reporting and other issues (e.g. extreme baseline imbalance) see Appendix 4 for details of criteria on which the judgement were based. We assessed blinding and completeness of outcome data for each outcome separately.

\section{Measures of treatment effect}

For dichotomous outcomes, we calculated risk ratio (RR) plus 95\% confidence intervals $(\mathrm{Cl})$. If continuous outcomes had been reported, we would have calculated mean difference (MD) plus
$95 \%$ confidence intervals. We would also have analysed time-toevent data (e.g. time to ulceration) as survival data, using the appropriate analytical method (as per the Cochrane Handbook for Systematic Reviews of Interventions; Deeks 2011). If time-to-event data had been incorrectly presented as continuous data, we would have presented the data in a narrative format in the review. We planned to collect data only from those trials where scales had been validated and were self-reported or completed by an independent rater or relative (not the therapist or investigator). We planned to use the standard mean difference as the summary statistic in any meta-analysis of such data (Deeks 2011).

\section{Unit of analysis issues}

Ideally a trial would be designed with participant-level randomisation and analysis, and there would only be one pressure ulcer per participant (adjustment for clustering not necessary in this case), however, in pressure ulcer literature it is not unusual to find trials that report outcomes for multiple pressure ulcers per randomised participant without adjusting for the cluster effect.

In such cases we planned to contact the trial authors to attempt to obtain:

- participant-level data or results;

- data or results for one pressure ulcer per participant; or

- pressure ulcer-level data,

and then perform multilevel regression to calculate the adjusted effect. We would then have combined the adjusted results in the meta-analysis with those of participant-level trials (using the generic inverse method), and performed sensitivity analyses (Higgins 2011c). If we had been unsuccessful in obtaining the additional data required, then we would have excluded the trial from the meta-analysis.

\section{Dealing with missing data}

If there was evidence of missing data, we contacted the trial authors to request the information. Where trial authors could not provide missing data, we assessed the risk of bias of the missing data and decided if the missing data were of 'low' or 'high' risk of bias according to our 'Risk of bias' criteria (Higgins 2011b). Or, if we considered data to be missing at random, we analysed the available information. Where outcome data were missing, we used an available-case analysis, based on the numbers of participants for whom outcome data were known.

\section{Assessment of heterogeneity}

We explored clinical heterogeneity by examining potentially influential factors, for example, type of topical agent or dressing, care setting, or participant characteristics, such as level of mobility. 
We assessed statistical heterogeneity using the $\mathrm{I}^{2}$ measure (Higgins 2003). This examines the percentage of total variation across trials due to clinical or methodological heterogeneity, or both, rather than to chance. Values of $\mathrm{I}^{2}$ over $75 \%$ indicate a high level of heterogeneity.

\section{Assessment of reporting biases}

Reporting bias was assessed using guidelines in the Cochrane Handbook for Systematic Reviews of Interventions (Higgins 2011a). Reporting bias may occur for a number of reason, including a greater likelihood of studies being published that report positive findings, and selective reporting of only those outcomes that favour the experimental intervention. We assessed reporting bias in each study as part of our 'Risk of Bias' evaluation. If sufficient study data had been available for individual outcomes (> 10 trials), funnel plots would have been developed and inspected for evidence of publication bias.

\section{Data synthesis}

We conducted a structured narrative summary of the trials reviewed. We entered quantitative data into Review Manager 5 (RevMan 5) (RevMan 2014), and conducted analyses using RevMan 5 software. For dichotomous outcomes, we calculated risk ratios (RR) with 95\% confidence intervals $(\mathrm{Cl})$. RR is the ratio of the risk of the event of interest (e.g. pressure ulcers developed) in the experimental group divided by the risk of this event in the control group and indicates the chances of pressure ulcer development for people in the experimental group compared with the control group (Deeks 2011). An RR of 1 means that there is no difference between two groups in terms of their risk of pressure ulcer development, whereas an RR of greater than 1, or of less than 1, usually means that use of a specific topical agent or dressing either increases (RR $>1$ ) or decreases $(R R<1)$ the risk of pressure ulcer development (Deeks 2011). As, by definition, the risk of an event occurring in the control group is 1 , then the $R R$ reduction associated with using an experimental treatment is $1-\mathrm{RR}$. The RR indicates the relative benefit of a therapy, but not the actual benefit, that is, it does not take into account the number of people who would have developed a pressure ulcer anyway, without the intervention (Deeks 2011).

We carried out statistical pooling on groups of trials that we considered to be sufficiently similar (where populations, interventions and methods were considered sufficiently similar). Where heterogeneity was absent or low ( $12=0 \%$ to $25 \%)$ we used a fixed-effect model; if there was evidence of heterogeneity $(12$ more than $25 \%$ ), we used a random-effects model. If heterogeneity was very high ( 12 over $75 \%$ ) we did not plan to pool trials.

\section{Subgroup analysis and investigation of heterogeneity}

We planned to conducted a subgroup analyses investigating the effects of any dressing or topical application in:

- trials conducted in the community versus trials conducted in hospitals to compare effects due to differences in patient characteristics.

However, we were unable to conduct this analysis because none of the outcomes in any comparison contained trials that were conducted in both the hospital and in the community.

\section{Sensitivity analysis}

We performed a sensitivity analysis by only including trials that we had assessed as having a low risk of bias in these domains: generation of the randomisation sequence, allocation concealment and blinding of outcome assessor and where no other domains were judged as being at high risk of bias.

\section{'Summary of findings' tables and GRADE assessment of the certainty of evidence}

We have presented the main results of the review in 'Summary of findings' tables. 'Summary of findings' tables present key information concerning the quality of the evidence, the magnitude of the effects of the interventions examined, and the sum of the available data for the main outcomes (Schünemann 2011a). 'Summary of findings' tables also include an overall grading of the evidence related to each of the main outcomes using the GRADE approach (Schünemann 2011b), which defines the quality of a body of evidence with regard to the extent to which one can be confident that an estimate of effect or association is close to the quantity of specific interest. To assess the overall body of evidence, we developed 'Summary of findings' tables using GRADEpro GDT 2015.

We included 'Summary of findings' tables for comparisons where:

- the intervention was similar but controls differed, as long as there was no significant clinical or statistical heterogeneity between trials;

- the intervention and controls were similar between trials.

We assessed the quality of the body of evidence against five principle domains: limitations in design and implementation; indirectness of evidence or generalisability of findings; inconsistency of results, for example, unexplained heterogeneity and inconsistent findings; imprecision of results where confidence intervals are wide; and publication bias (Schünemann 2011b). We used the following decision rules for downgrading the evidence, for each of the five domains:

- If no serious concern had existed, we would not have downgrade quality from the baseline quality (e.g. high for RCTs)

- If serious concern existed, we downgraded the evidence one level, e.g. from high to moderate (-1)

- If very serious concern existed, we downgraded the evidence two levels, e.g. from high to low (- 2) (Ryan 2016).

We present the following outcomes in 'Summary of findings' tables.

- Pressure ulcer incidence (the proportion of people developing any new pressure ulcer(s) of any stage)

- Pressure ulcer stage

- Adverse events.

\section{RES U L T S}

\section{Description of studies \\ Results of the search}

The original search identified 19 potentially relevant trials; nine of which were included in the review. The updated search yielded 496 records and we found six additional records from other sources. For this update, after two review authors had independently screened 
titles and abstracts, we retrieved full texts of 21 articles and six clinical trials registry reports. Of these we excluded six trials with reasons (see Characteristics of excluded studies), six trials were added to Studies awaiting classification and six trials noted as Ongoing studies. Nine new trials were included in this update (see Figure 1). Therefore, this review now includes 17 published trials and one unpublished trial, yielding a total of 18 trials.

\section{Included studies}

See the Characteristics of included studies table.

We included results from 18 trials with a total of 3629 participants (range 52 to 831 participants) in the review (Chiew 2010; DiazValenzuela 2014; Dutra 2015; Forni 2018; Green 1974; Han 2011; Houwing 2008; Kalowes 2016; Lupianez-Perez 2015; Nakagami 2007; Otero 2017; Qiuli 2010; Saab 2015; Santamaria 2015; Smith 1985; Torra i Bou 2005; Van Der Cammen 1987; Walker 2015), one of which was a cluster-RCT (Houwing 2008) and one an unpublished trial (Forni 2018). We attempted to contact seven trial authors to seek additional information. We were unable to locate Green 1974, no response was received from the authors of Han 2011; Qiuli 2010; Torra i Bou 2005 or Van Der Cammen 1987, but Houwing 2008 and Kalowes 2016 responded and provided answers to several questions. We originally contacted investigators of four protocols published in trials registries and received responses from all of the trialists. Data collection is still ongoing in five trials (NCT02565745; NCT02295735, NCT03039179, JPRN-UMIN000024609; RBR-4s8qjx) and results are embargoed until publication in one trial (NCT01640418).

\section{Participants}

The mean age of participants in 17 of the trials varied between 55 and 86 years (Diaz-Valenzuela 2014; Dutra 2015; Forni 2018; Green 1974; Han 2011; Houwing 2008; Kalowes 2016; LupianezPerez 2015; Nakagami 2007; Otero 2017; Qiuli 2010; Saab 2015; Santamaria 2015; Smith 1985; Torra i Bou 2005; Van Der Cammen 1987; Walker 2015). Chiew 2010 recruited people who were 76 years of age or older.

Four of the trials were conducted in Spain (Diaz-Valenzuela 2014; Lupianez-Perez 2015; Otero 2017; Torra i Bou 2005), three in the UK (Green 1974; Smith 2010; Van Der Cammen 1987), two in Australia (Santamaria 2015; Walker 2015), China (Han 2011; Qiuli 2010 and the USA (Kalowes 2016; Saab 2015), and one each in Brazil (Dutra 2015), Italy (Forni 2018), Japan (Nakagami 2007), the Netherlands (Houwing 2008), and Singapore (Chiew 2010).

An inclusion criterion for seven trials was that the individuals were at high risk of pressure ulcer development according to the Braden (Bergstrom 1987) pressure ulcer risk assessment scale (Diaz-Valenzuela 2014; Dutra 2015; Houwing 2008; Kalowes 2016; Lupianez-Perez 2015; Nakagami 2007; Torra i Bou 2005). For one trial the individuals had a Norton pressure sore risk-assessment scale (Norton 1975) score of between five and 14 (meaning high or very high risk) (Van Der Cammen 1987), and for a further trial the participants had a Waterlow score (Waterlow 1985) of 18-23 (meaning high or very high risk) (Qiuli 2010). In the trial of (Walker 2015) participants were those assessed as having a risk assessment score of $15+$ on the Waterlow scale (Waterlow 1985), indicating that they were at high risk for the development of pressure ulcers. The remaining trials used other risk criteria. For example, Green 1974 used what was defined as a "clinical risk score"', Smith 2010 included elderly continuing care patients with "intact skin"; Chiew 2010 recruited elderly, high-risk orthopaedic patients and Santamaria 2015 included high-risk ICU patients. Forni 2018 included patients aged 65 years and older with hip fragility fracture. It was unclear what inclusion criteria Han 2011 or Saab 2015 used. In Otero 2017, the inclusion criteria were adult patients over the age of 18 years, with acute respiratory failure requiring noninvasive ventilation (NIV), without facial soft tissue injury, or facial anatomy structural deformity.

Five trials included elderly hospital or nursing home patients (DiazValenzuela 2014; Green 1974; Houwing 2008; Nakagami 2007; Smith 1985); three included internal medicine or surgical patients at high risk of pressure injury (Chiew 2010; Torra i Bou 2005; Walker 2015). Participants in Han 2011 were admitted with a posterior spinal injury; in Van Der Cammen 1987 participants were hospitalised and chair-bound; participants in Dutra 2015; Kalowes 2016; Saab 2015 and Santamaria 2015 were nursed in a medical/surgical/trauma intensive care unit or a cardiac intensive care unit; Forni 2018 included hip fracture patients, Qiuli 2010 enrolled patients with paralysis or coma; and participants in the Lupianez-Perez 2015 trial were immobilised patients living at home. Otero 2017 included individuals nursed in a high-dependency unit at a university hospital.

\section{Interventions}

See Additional tables; Table 1 for the composition of the topical agents and dressings.

\section{Topical applications}

We included eight trials where a topical application was the intervention of interest.

Green 1974's intervention was a lotion described as "active", containing hexachlorophane $0.5 \%$, saturated hydrocarbons (squalene (Cosbiol $3 \%$ ) and glyoxyle diureide), allantoin $0.2 \%$, antioxidants, lanolin, fatty acids, fatty acid esters, fatty alcohols, preservatives and distilled water. For the control group they applied a lotion described as "inert" containing lanolin, fatty acids, fatty acid esters, fatty alcohols, preservatives, distilled water and mineral oils. They applied the lotions manually to pressure areas (sacral, trochanteric, heel and shoulder and other areas, as indicated), and avoided excess friction. They inspected the participants' skin every two hours, and, if the participant was incontinent, they washed the skin with soap and water, then dried it and applied the relevant lotion. In the absence of incontinence, they carried out routine washing and reapplication of lotion every six hours.

Smith 1985 used Conotrane as the topical application for the intervention, which contains silicone cream, 20\% dimethicone 350 and a broad spectrum antiseptic (0.05\% hydrargaphen). They described the topical application in the control group as a bland cream known as Unguentum. For both groups, as part of the routine skin care regimen, they washed participants' skin when required, with water, then dried thoroughly and applied the ointment.

Van Der Cammen 1987 used Prevasore as the topical application, which contains hexyl nicotinate, zinc stearate, isopropyl myristate, Dimethicone 350, cetrimide and glycol. The control group topical application was Dermalex, which contains hexachlorophane, squalene and allantoin. In both groups they washed and dried the 
participants' buttocks and sacral areas, and applied the topical application at least twice daily, and again after changing, if the individual was wet or soiled.

Torra i Bou 2005 used Mepentol as the topical application for the intervention group, a hyperoxygenated fatty acid compound consisting of oleic acid, palmitic acid, stearic acid, palmitoleic acid, linoleic acid, gamma linoleic acid, arachidonic acid, and eicosenoic acid. The control group topical application was a compound consisting of trisostearin (99.4\%) and perfume (0.6\%). In both groups, they applied the topical application twice daily to at least three areas of the body, sacrum, trochanter and heels.

Houwing 2008 massaged the intervention group with the topical application, "DMSO-cream". The DMSO cream consisted of 5\% dimethyl sulfoxide in Vaseline-cetomacrogol cream; participants also had a $30^{\circ}$ position change every six hours. The placebo group topical application was a three-minute massage of the buttock, heel, and ankle regions with an "indifferent" cream (Vaselinecetomacrogol), combined with a $30^{\circ}$ position change every six hours for four weeks. For the control group, no topical application was applied, but the participants had a $30^{\circ}$ position change every six hours for four weeks.

Chiew 2010 used a solution of $99 \%$ of hyperoxygenated glycerides of essential fatty acids (including linoleic acid (60\%), linolenic acid, tocopherol (vitamin E) and aniseed perfume 1\%, known as Sanyrene, combined with two- to three-hourly changes of position (treatment) in the intervention group. They applied the topical agent on the participants' sacrum, buttocks and heels at every change of position from the day of admission. The control group received two- to three-hourly changes of position only.

Diaz-Valenzuela 2014 compared a hyperoxygenated fatty acid compound, Mepentol in the control group with extra virgin olive oil (Oleicopiel) in the experimental group. They applied the topical treatments every 12 hours to risk areas of the skin.

Lupianez-Perez 2015 compared a hyperoxygenated fatty acid product containing Equisetum arvense, Hypericum perforatum and perfume in the intervention group, with an olive oil product containing $97 \%$ extra virgin olive oil and 3\% Hypericum perforatum and peppermint in the control group. They used two applications of the topical treatments on the skin areas of the sacrum, hips and heels.

None of the trials using topical applications applied any additional dressings. They applied the topical agent directly to the skin and the skin was then left bare.

\section{Dressings}

A dressing was the intervention of interest in nine included trials.

Nakagami 2007 used a dressing known as PPD (pressure ulcer preventive dressing) in the intervention group. This consists of a skin adhesive layer (hydrocolloid) containing an intercellular lipidceramide, a support layer (urethane film) and an outer layer of multi-filament nylon fibres. They applied the dressing to either the right or left greater trochanter (depending on randomisation) of the participant. The dressing was replaced weekly. No dressing was applied in the control arm of the trial.
Qiuli 2010's intervention was a soft silicone, self-adherent, bordered multilayer foam dressing applied to the integral skin site of pressed bone protuberance. The paper did not mention the frequency of dressing changes. For the control group, at each patient-turning episode (two- to three-hourly), they massaged the site of bone protuberance. The paper did not mention the duration of massage. Both groups were nursed on air cushion mattresses and repositioned every two to three hours.

Han 2011 used a polyurethane film and foam dressing (Kang' huier transparent strip and foam dressing) as the intervention. They applied the dressing to the pressure areas of the participants during surgery. The control group did not have any dressings applied.

Kalowes 2016's intervention was a soft silicone, self-adherent, bordered multilayer foam dressing applied to the participants' sacrum. They changed the dressing every three days, or as needed. The control group did not have any dressing applied to the participants' skin. Both groups were nursed according to the SKIN bundle (Surface, Keep turning, Incontinence and Nutrition) (Gibbons 2006).

Walker 2015 also used a silicone foam, multilayer, border dressing applied to the participants' sacra as the intervention. They replaced the dressing every three days, or sooner if it became loose or soiled. The control group had no dressing applied. All trial participants continued to receive routine pressure ulcer prevention care, as per hospital policy.

Santamaria 2015's intervention group had a silicone, multilayer, foam border dressing applied to their sacra and both heels (the heel dressings were retained with elastic tubular bandages) on admission to the emergency room. Dressings were left in place until transfer to ICU, then the dressings were maintained on the sacrum and heels throughout the participant's ICU stay and changed every three days unless they became soiled or dislodged. The control group had no dressing applied. All trial participants continued to receive standard pressure ulcer prevention care, which included ongoing Braden pressure ulcer risk assessment and regular repositioning and skin care.

Dutra 2015 used two dressings. One group of participants received a transparent polyurethane film and the other group received a hydrocolloid dressing. They applied the dressings bilaterally to the trochanteric and sacral regions of the participants and changed them only if there was loss of adhesiveness, shear, excessive moisture, friction, presence of wrinkles, or the combination of these factors.

Saab 2015 used a multi-layered dressing incorporating hydrocellular foam with a silicone wound contact layer, applied to the sacrum, in the intervention group. They examined the buttocks and the sacrum daily and replaced the dressing as needed. The control group received no dressing, however, for both groups, standard care bundles to prevent pressure ulcers were continued.

Forni 2018 used a multi-layered dressing incorporating hydrocellular foam, hyper-absorber, lock-away core with a silicone wound contact layer in the intervention group, which was applied to the sacral region within 24 hours of admission and replaced when detached, wet or dirty. The control group received no dressings. Both groups received standard pressure ulcer prevention care, which included, a pressure mattress (static or alternating 
pressure) if Braden score was over 18, daily inspection of the skin in the various pressure points and repositioning every four hours after surgery, management of possible incontinence, humidity control and prevention of skin damage and rubbing/friction during postural changes as per hospital procedure.

\section{Topical application and dressing}

Otero 2017 had 4 arms. They compared a control group (group A) with two dressings groups (group B and group C) and one topical application group (group D). Group B received an adhesive thin dressing (ATD). The oro-nasal mask was applied over skin protected with an adhesive thin polyurethane foam dressing (Allevyn Thin; Smth and Nephew). The ATD foam dressing consists of a layer of hydrophilic polyurethane matrix, and a semipermeable polyurethane film and a perforated polymeric wound contact layer. This inner layer is coated with a hypoallergenic acrylic adhesive. Group $C$ received an adhesive foam dressing (AFD). The oro-nasal mask was applied over skin protected with AFDs. The adhesive foam is a two-layered non-adherent dressing made from a breathable hydrophilic polyurethane foam layer and a thin semipermeable transparent and protective polyurethane film, which is waterproof and bacteria-resistant (Askina Foam; B. Braun). The preventive intervention for participants in groups $B$ and $C$ included placing dressings over the nasal bridge and cheekbones. Group D (hyperoxygenated fatty acids (HOFA)): the oro-nasal mask was applied over skin protected with a solution of HOFA, gently applied without rubbing on the chin, cheekbones, nasal bridge and forehead.

\section{Outcomes}

All the trials included the development of a pressure ulcer as their primary outcome. Two used the EPUAP 1999 validated scale (Houwing 2008; Nakagami 2007). Three used the NPUAP/ EPUAP/PPPIA 2014 validated scale (Diaz-Valenzuela 2014; Forni 2018; Walker 2015). Han 2011 reported use of an international measurement for pressure ulcers titled "WCET" (Black 2007). Green 1974 used a five-point scale. Smith 1985 used the Barbarel 1977 classification. Van Der Cammen 1987 used a five-point scale. Santamaria 2015 used the four point staging system of the Australian Wound Management Association. Otero 2017 used the GNEAUPP (Grupo Nacional para el Estudio y Asesoramiento en Úlceras por Presión y Heridas Crónicas) classification for pressure ulcer staging (García-Fernández 2014). Finally, Chiew 2010; Dutra 2015; Kalowes 2016; Lupianez-Perez 2015; Qiuli 2010; Saab 2015; and Torra i Bou 2005 did not identify the classification system used.

\section{Ethics and consent}

Chiew 2010; Green 1974; Han 2011; Kalowes 2016; Qiuli 2010; Saab 2015; and Van Der Cammen 1987 did not provide any information about ethics approval or participant consent and, although Santamaria 2015 and Smith 1985 had ethics approval, they did not report participants' consent. The remaining trials provided information on ethics and consent (Diaz-Valenzuela 2014; Dutra 2015; Forni 2018; Houwing 2008; Lupianez-Perez 2015; Nakagami 2007; Otero 2017; Torra i Bou 2005; Walker 2015).

\section{Funding}

Eight of the 18 trials reported receiving support from the manufacturers of the interventional product (Green 1974; Han 2011; Kalowes 2016; Nakagami 2007; Santamaria 2015; Smith 1985; Torra i Bou 2005; Van Der Cammen 1987). Sponsorship was not declared in Chiew 2010; Otero 2017; Qiuli 2010; or Saab 2015. Investigators in Nakagami 2007 were involved in developing the dressing used in the trial. The corresponding author in Van Der Cammen 1987 was an employee of the company producing the intervention product. The manufacturers provided the dressings in Forni 2018 but there was a written agreement between the institute and the manufacturers stating that Smith \& Nephew would have no influence over data trial methods. Four trials received funding from a non-commercial source (Diaz-Valenzuela 2014; Dutra 2015; Lupianez-Perez 2015; Walker 2015) and one trial did not state whether funding was received (Houwing 2008).

\section{Excluded studies}

We excluded a total of 16 trials. Eight trials were not RCTs (Alvarez Vázquez 2014; Callaghan 1998; Declaire 1997; Hsu 2011; Huang 2009; Park 2014a; Smith 2010; Wen-Yi 2013); one was a crossover trial (Duimel-Peeters 2007); one was a cost analysis from an unpublished trial with limited information (Torra i Bou 2009); two considered interventions for treating pressure ulcers rather than preventing them (Kuisma 1987; Stoker 1990); three were duplicates (Garcia Fernandez 2005; Park 2014b; Santamaria 2013); and one was included in a previous version of the review (Kalowes 2013). See the Characteristics of excluded studies table for details.

\section{Risk of bias in included studies}

See Figure 2 for the risk of bias summary and Figure 3 for the risk of bias graph, of the included trials. 
Figure 2. Risk of bias summary: review authors' judgements about each risk of bias item for each included study

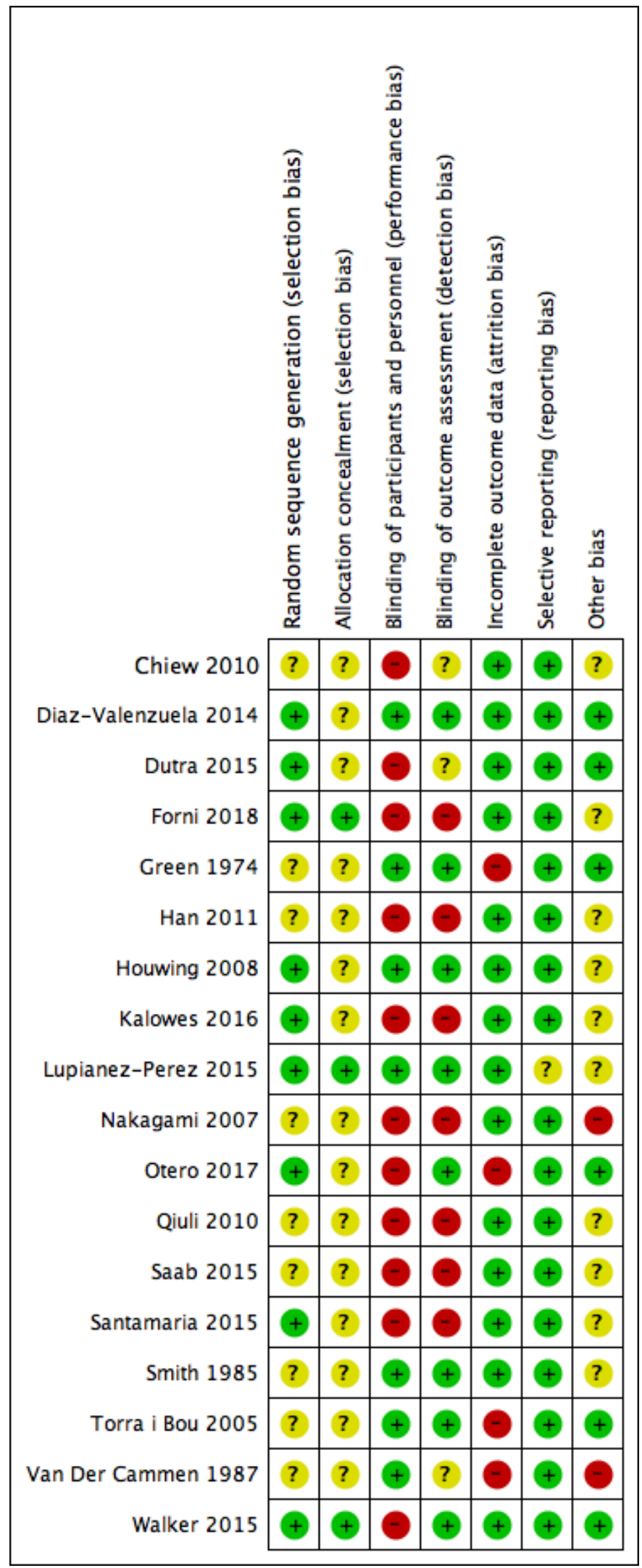


Figure 3. Risk of bias graph: review authors' judgements about each risk of bias item presented as percentages across all included studies

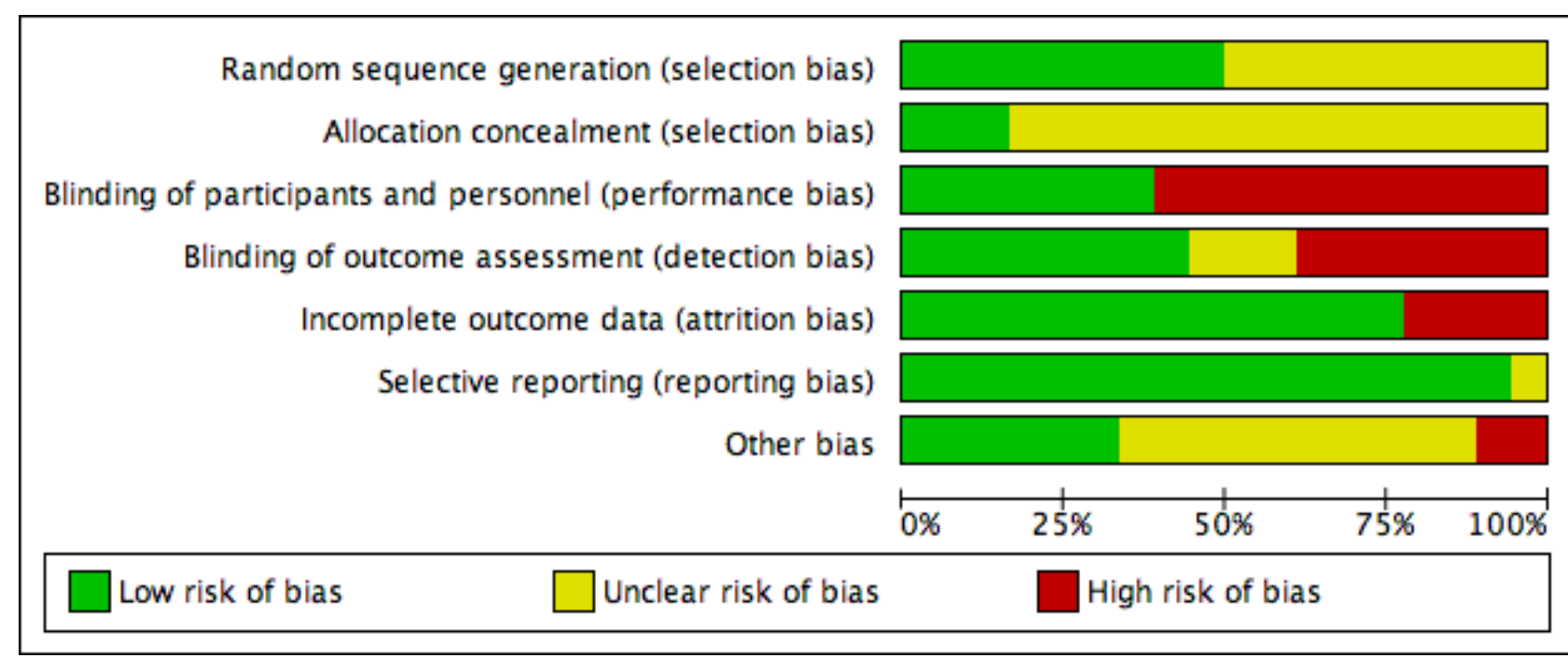

Allocation

\section{Random sequence generation}

Nine of the trials provided details of appropriate methods used for generating the allocation sequence (Diaz-Valenzuela 2014; Dutra 2015; Forni 2018; Houwing 2008; Kalowes 2016; Lupianez-Perez 2015; Otero 2017; Santamaria 2015; Walker 2015) and were judged low risk of bias in this domain. Five trials used a computergenerated list (Diaz-Valenzuela 2014; Forni 2018; Lupianez-Perez 2015; Santamaria 2015; Walker 2015); one stated that they had used a lottery to generate the sequence (Dutra 2015), one trial used the throw of a dice to generate the sequence (Houwing 2008) and Otero 2017 randomised individuals using specifically designed random number tables. The remaining nine trials did not state their method for sequence generation and were therefore judged at unclear risk of bias in this domain.

\section{Allocation concealment}

Forni 2018 used sequentially numbered, sealed, opaque envelopes for concealing the group allocation; Lupianez-Perez 2015 used a phone call to a remote site; and Walker 2015 allocated via an online clinical co-ordinating web site, these three trials were judged to be at low risk of bias in this domain. For 15 trials, the method for concealing group allocation was unclear and thus, these trials were judged to be at unclear risk of allocation concealment bias.

\section{Blinding}

Of the trials using a topical agent, seven were blinded to participants and personnel (Diaz-Valenzuela 2014; Green 1974; Houwing 2008; Lupianez-Perez 2015; Smith 1985; Torra i Bou 2005; Van Der Cammen 1987), and eight reported blinding of the outcome assessor (Diaz-Valenzuela 2014; Green 1974; Houwing 2008; Lupianez-Perez 2015; Otero 2017; Smith 1985; Torra i Bou 2005; Walker 2015). Blinding of participants and personnel was not possible for any of the dressings trials, due to the difference in the appearance of the intervention. However, the outcome assessor was blinded in Walker 2015, who used photography to assess the presence of pressure ulcers. Otero 2017 reported that they assessed outcomes using independent double evaluations but the assessors were not blinded to the intervention. None of the other dressings trials blinded outcome assessment (Forni 2018; Han 2011; Kalowes 2016; Nakagami 2007; Qiuli 2010; Saab 2015; Santamaria 2015).

In summary, Diaz-Valenzuela 2014; Green 1974; Houwing 2008; Lupianez-Perez 2015; Smith 2010; Torra i Bou 2009 and Van Der Cammen 1987 were judged to be at low risk of performance bias. All other trials (Chiew 2010; Dutra 2015; Forni 2018; Han 2011; Kalowes 2016; Nakagami 2007; Otero 2017; Qiuli 2010; Saab 2015; Santamaria 2015; Walker 2015) were judged to be at high risk of performance bias.

Diaz-Valenzuela 2014; Green 1974; Houwing 2008; Lupianez-Perez 2015; Otero 2017; Smith 1985; Torra i Bou 2005 and Walker 2015 were judged to be at low risk of detection bias. Chiew 2010, Dutra 2015 and Van Der Cammen 1987 were judged to be at unclear risk of detection bias. All other trials (Forni 2018; Han 2011; Kalowes 2016; Nakagami 2007; Qiuli 2010; Saab 2015; Santamaria 2015) were judged to be at high risk of detection bias.

\section{Incomplete outcome data}

We judged outcome data reporting to be complete in 14 trials, which were judged to be at low risk of attrition bias (Chiew 2010; Diaz-Valenzuela 2014; Dutra 2015; Forni 2018; Han 2011; Houwing 2008; Kalowes 2016; Lupianez-Perez 2015; Nakagami 2007; Qiuli 2010; Saab 2015; Santamaria 2015; Smith 1985; Walker 2015). Four trials excluded from the analysis $9 \%$ to $48 \%$ of those recruited, so we judged these trials to be at high risk of attrition bias (Green 1974; Otero 2017; Torra i Bou 2005; Van Der Cammen 1987).

\section{Selective reporting}

One trial (Lupianez-Perez 2015) did not report all outcomes outlined in the study protocol, and was therefore judged to be at unclear risk of reporting bias. All remaining trials provided information on the outcomes identified in their trial methods, so we considered them to be at low risk of reporting bias. Only five of the trials had registered their protocol in a trials registry database (Forni 2018; Lupianez-Perez 2015; Otero 2017; Santamaria 2015; Walker 2015). 


\section{Other potential sources of bias}

In Smith 1985, 33\% more participants in the placebo group were incontinent for urine, and 25\% more were incontinent for faeces, than in the treatment group and they did not adjust for this in the analysis. We had only limited information about the methods used in Han 2011, and only abstracts from conference presentations were available to interpret for Chiew 2010 and Saab 2015, so it is possible that there may have been biases about which we were unaware. Qiuli 2010 did not provide any baseline characteristics, so it is unclear if risks for the development of pressure ulcers were equal between groups. Houwing 2008 analysed data by individual, rather than by cluster. Insufficient information was available for us to correct the trial results by using one of the methods suggested in the Cochrane Handbook for Systematic Reviews of Interventions (Higgins 2011c); including this trial in the meta-analyses may have over-estimated the effect size. The authors of Nakagami 2007 and Van Der Cammen 1987 were part of the group that developed the intervention products, thus introducing a high risk of for bias, for example, overestimating the treatment effect. In addition, in the study Santamaria 2015, the sample size calculation was based on a control event rate of $4.0 \%$ (presumably this was known from existing hospital data). In the study, the control event rate was $13.1 \%$, raising questions about the accuracy of PU diagnosis in the control group during the study.

\section{Effects of interventions}

See: Summary of findings for the main comparison Fatty acid versus other topical intervention or standard care for preventing pressure ulcers; Summary of findings 2 Active topical agent versus placebo/control for preventing pressure ulcers; Summary of findings 3 Silicone dressing compared with no dressing for preventing pressure ulcers; Summary of findings 4 Other dressing versus control for preventing pressure ulcers

\section{How the results are presented and what the terms mean}

We have presented results for dichotomous variables RR with $95 \% \mathrm{Cl}$. We generated four comparisons to report outcomes (fatty acid versus other topical applications; active topical agents versus placebo; silicone dressing versus no dressing; and experimental dressing versus placebo, control or no dressing).

\section{Comparison 1: fatty acid versus other topical applications (5 trials 1323 participants)}

\section{Primary outcome}

Pressure ulcer incidence (proportion of participants developing any new pressure ulcer(s) of any stage)

\section{Analysis 1.1; Summary of findings for the main comparison}

In the pooled data from two trials Diaz-Valenzuela 2014; LupianezPerez 2015 there is no clear difference in pressure ulcer incidence when fatty acids were compared with olive oil (fatty acid: $29 / 511$, $6 \%$; control: $24 / 549,4 \%$; RR 1.28 ; $95 \% \mathrm{Cl} 0.76$ to 2.17 ; low-certainty evidence, downgraded twice for very serious imprecision due to the small number of events and a wide $\mathrm{Cl}$ ). Torra i Bou 2005 found that fatty acid may reduce pressure ulcer incidence (fatty acid: 12/164, 7.3\%; control: 29/167, 17.4\%; RR 0.42; $95 \% \mathrm{Cl} 0.22$ to 0.80 ; low-certainty evidence, downgraded once for serious risk of bias due to attrition bias and downgraded once for serious imprecision due to the small number of events). Two trials compared a fatty acid with standard care (Chiew 2010; Otero 2017) and there is no clear difference in pressure ulcer incidence (fatty acid: $18 / 93$, $19 \%$; standard care: $26 / 94,28 \%$; RR $0.70,95 \%$ Cl 0.41 to 1.18 ; lowcertainty evidence, downgraded once for serious risk of bias due to performance bias and downgraded once for serious imprecision due to a wide $\mathrm{Cl}$ ) See Figure 4.

Figure 4. Forest plot of comparison 1. Fatty acid versus other topical intervention or standard care, outcome: 1.1 Pressure ulcer

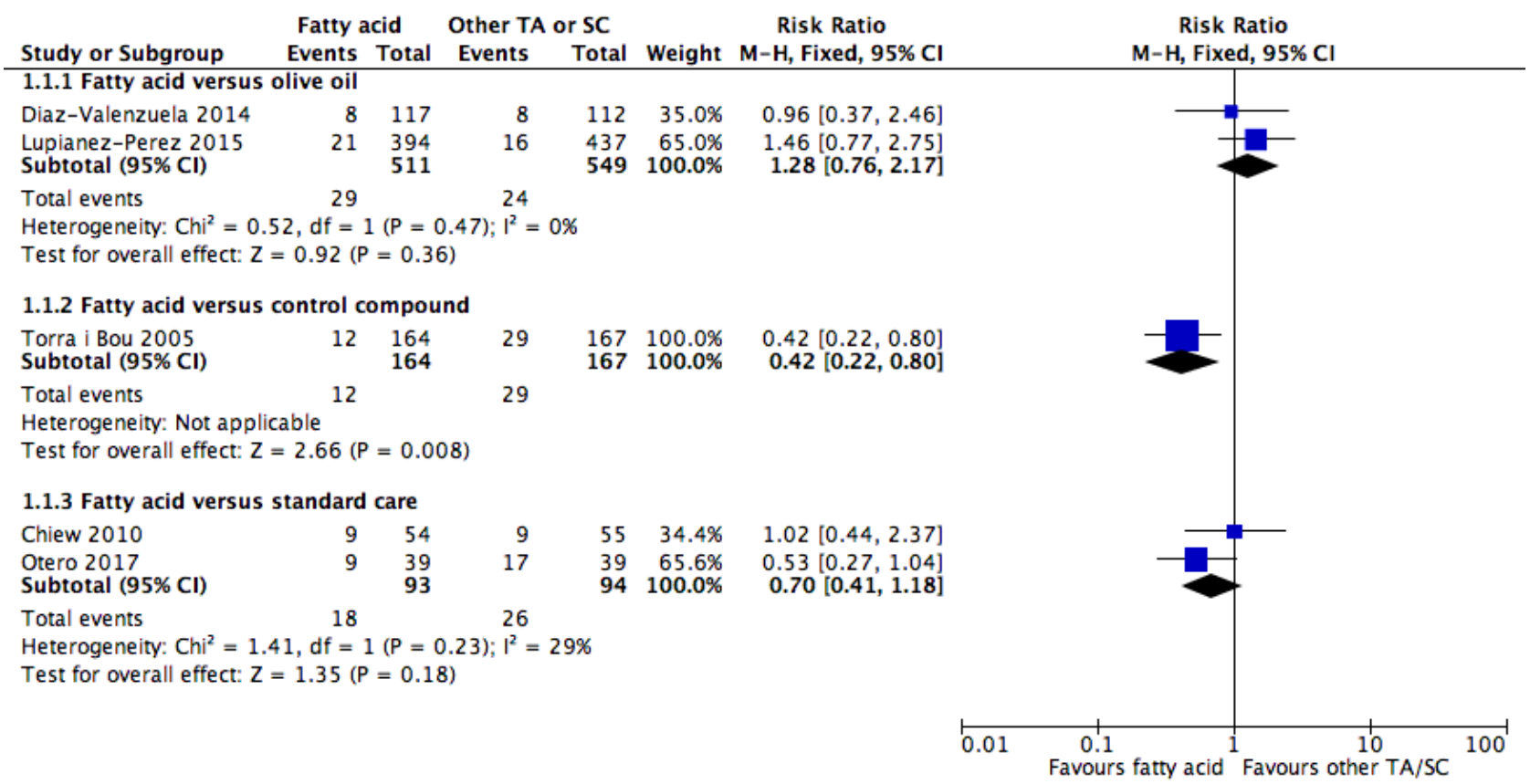




\section{Sensitivity analysis}

We considered only one trial in this comparison to be at low risk of bias for the specified domains (allocation sequence generation, allocation concealment and blinding of outcome assessor) (Lupianez-Perez 2015). This study reported no clear difference in pressure ulcer incidence between fatty acid and olive oil treatments (fatty acid: 21/394, 5.3\%; olive oil: 16/437 3.7\%; RR $1.46 ; 95 \% \mathrm{Cl} 0.77$ to 2.75 ; low-certainty evidence, downgraded twice for very serious imprecision due to a very wide confidence interval and very small number of events; Analysis 1.2).

\section{Secondary outcomes}

\section{Stage of any pressure ulcers}

None of the trials provided data for this outcome.

\section{Time to pressure ulcer development}

Kaplan-Meier survival curves used in the Torra i Bou 2005 trial (331 participants), indicated that pressure ulcer development was delayed among people in the intervention group; the reported $\mathrm{P}$ value was 0.005 .

\section{Cost of interventions}

Torra i Bou 2005 was the only trial to report costs for this comparison. Trial authors reported that the cost of the intervention product (Mepentol) was approximately EUR 9.3 per month, but they did not provide any comparison cost data.

\section{Quality of life (measured by any validated scale)}

None of the trials provided data for this outcome.

\section{Pain at dressing change (measured by any validated scale)}

None of the trials provided data for this outcome.

\section{Acceptability of/satisfaction with the intervention (with respect to participants' comfort)}

None of the trials provided data for this outcome

\section{Adverse events}

Chiew 2010 and Diaz-Valenzuela 2014 reported that no adverse events occurred during their trials. There was no clear difference in adverse events (itching or redness) reported by Lupianez-Perez 2015; (fatty acid: 0.5\%, 2/394; olive oil: 0.5\%, 1/437; RR 2.22; 95\% $\mathrm{Cl} 0.20$ to 24.37 ; low-certainty evidence, downgraded twice for very serious imprecision due to a very small number of events leading to a very wide $\mathrm{Cl}$; Analysis 1.3; Summary of findings for the main comparison).

\section{Length of hospital stay}

None of the trials provided data for this outcome

\section{Comparison 2: active topical agent versus placebo (4 trials 773 participants)}

Each of the four trials included in this comparison used different intervention products (see Table 1) and comparators (Green 1974; Houwing 2008; Smith 1985; Van Der Cammen 1987).

\section{Primary outcome}

Pressure ulcer incidence (proportion of participants developing any new pressure ulcer(s) of any stage)

Analysis 2.1; Summary of findings 2

One trial (Houwing 2008) compared DMSO cream with a placebo. DMSO cream may increase the risk of pressure ulcer incidence (placebo: 10/32, 31.3\%; DMSO 18/29, 62.1\%; RR 1.99; 95\% Cl 1.10 to 3.57 ; low-certainty evidence, downgraded once for serious risk of bias due to unclear risk of selection bias and downgraded once for serious imprecision due to a wide $\mathrm{Cl}$ ). In the other three trials (Green 1974; Smith 1985; Van Der Cammen 1987) there was no clear difference in pressure ulcer incidence between active topical agents and control/placebo; Green 1974: placebo 34\%, 31/91; Active lotion 25\%, 19/76; RR 0.73, (95\% Cl 0.45 to 1.19$)$; Smith 1985: placebo 36\%, 47/129; Conotrane 27\%, 47/129; RR 0.74 (95\% Cl 0.52 to 1.07); Van Der Cammen 1987: placebo 5\%, 3/60; Prevasore 2\%, 1/60; RR $0.33(95 \% \mathrm{Cl} 0.04$ to 3.11$)$. We assessed the evidence in these trials as very low certainty, (downgraded twice for very serious risk of bias due to sequence generation, sequence allocation, and baseline imbalance; and once for serious imprecision due to wide $\mathrm{Cls}$ ).

Because of clinical heterogeneity, results were not combined for this outcome, nor did we develop a 'Summary of findings' table.

\section{Secondary outcomes}

\section{Stage of any pressure ulcers}

Analysis 2.2; Summary of findings 2

Smith 1985 (258 participants) demonstrated no clear difference in the incidence of third- or fourth-stage pressure ulcers when comparing Conotrane with placebo (stage 3: placebo 3\%, 4/129; Conotrane 4\%, 5/129; RR 1.25, 95\% Cl 0.34 to 4.55; stage 4: placebo $1 \%, 1 / 129$; Conotrane $0 \%, 0 / 129$; RR $0.33,95 \% \mathrm{Cl} 0.01$ to 8.11 ; very low-certainty evidence, downgraded twice for very serious risk of bias due to selection bias and other bias due to baseline imbalance; and downgraded once for serious imprecision due to a wide $\mathrm{Cl}$ ).

\section{Time to pressure ulcer development}

One trial (167 participants) assessed time to the development of a new pressure ulcer (Green 1974). In this trial, ulcers appeared approximately one day later in the intervention group, than in the placebo group (intervention 9.8 days versus placebo 8.7 days), but the trial report did not state whether these were means or medians).

\section{Cost of interventions}

None of the trials provided data for this outcome.

\section{Quality of life (measured by any validated scale)}

None of the trials provided data for this outcome.

\section{Pain at dressing change (measured by any validated scale)}

None of the trials provided data for this outcome.

\section{Acceptability of/satisfaction with the intervention (with respect} to participants' comfort)

None of the trials provided data for this outcome. 


\section{Adverse events}

Only Green 1974 reported data about adverse events. In their trial of 170 participants, two out of $76(2.6 \%)$ people in the intervention arm developed erythematous eruptions of the skin where the cream had been applied. A patch test indicated hypersensitivity to the product (Dermalex ${ }^{\mathrm{TM}}$, which is an emollient-based cream consisting of mainly hexachlorophane). There were no adverse events out of $91(0.0 \%)$ people in the control group (RR 6.14, 95\% $\mathrm{Cl} 0.29$ to 129.89 ; very low-certainty evidence, downgraded twice for very serious risk of bias due to high risk of attrition bias and unclear risk of selection bias and downgraded twice for very serious imprecision due to a very wide $\mathrm{Cl}$. Summary of findings 2

\section{Length of hospital stay}

None of the trials provided data for this outcome

\section{Comparison 3: silicone dressing versus no dressing (6 trials} 1247 participants)

\section{Primary outcome}

\section{Pressure ulcer incidence (proportion of participants developing any new pressure ulcer(s) of any stage)}

\section{Analysis 3.1; Summary of findings 3}

We were able to extract data from all of the trials for this outcome (Forni 2018; Kalowes 2016; Qiuli 2010; Saab 2015; Santamaria 2015; Walker 2015). Although populations varied, the intervention and comparators were similar in all trials and the statistical heterogeneity was $120 \%$; so we used a fixed-effect model to pool results. Silicone dressings may reduce pressure ulcer incidence at any stage (RR $0.25,95 \% \mathrm{Cl} 0.16$ to 0.41 ; silicone: $16 / 632,3 \%$; no dressing: 65/615, 11.0\%; low-certainty evidence, downgraded twice for very serious risk of bias due to high, or unclear risk of bias for multiple criteria, specifically selection and detection bias), Figure 5 .

Figure 5. Forest plot of comparison 3. Silicone dressing versus no dressing, outcome: 3.1 Any pressure ulcer

\begin{tabular}{|c|c|c|c|c|c|c|c|c|c|}
\hline Study or Subgroup & \multicolumn{2}{|c|}{ Silicone dressing } & No dressing & $\begin{array}{l}\text { sing } \\
\text { Total }\end{array}$ & Weight & $\begin{array}{c}\text { Risk Ratio } \\
\text { M-H, Fixed, } 95 \% \mathrm{Cl}\end{array}$ & \multicolumn{3}{|c|}{$\begin{array}{c}\text { Risk Ratio } \\
\mathrm{M}-\mathrm{H}, \text { Fixed, } 95 \% \mathrm{Cl}\end{array}$} \\
\hline Forni 2018 & 8 & 177 & 28 & 182 & $37.2 \%$ & $0.29[0.14,0.63]$ & -12 & & \\
\hline Kalowes 2016 & 1 & 184 & 7 & 182 & $9.5 \%$ & $0.14[0.02,1.14]$ & & & \\
\hline Qiuli 2010 & 0 & 26 & 3 & 26 & $4.7 \%$ & $0.14[0.01,2.63]$ & & & \\
\hline Saab 2015 & 0 & 45 & 6 & 35 & $9.8 \%$ & $0.06[0.00,1.03]$ & & & \\
\hline Santamaria 2015 & 7 & 161 & 27 & 152 & $37.4 \%$ & $0.24[0.11,0.55]$ & $\longrightarrow$ & & \\
\hline Walker 2015 & 2 & 39 & 1 & 38 & $1.4 \%$ & $1.95[0.18,20.61]$ & & & \\
\hline Total $(95 \% \mathrm{CI})$ & & 632 & & 615 & $100.0 \%$ & $0.25[0.16,0.41]$ & & & \\
\hline Total events & 18 & & 72 & & & & & & \\
\hline $\begin{array}{l}\text { Heterogeneity: } \mathrm{Chi}^{2}= \\
\text { Test for overall effect }\end{array}$ & $\begin{array}{l}4.46, d f= \\
Z=5.52(F\end{array}$ & $\begin{array}{l}=0.4 \\
0.0000\end{array}$ & $\begin{array}{l}\text { 9); }\left.\right|^{2}=0 \\
\text { D1) }\end{array}$ & & & & $\begin{array}{l}0.001 \\
\text { Favours silicone dressing }\end{array}$ & $\begin{array}{r}10 \\
\text { Favours no }\end{array}$ & 1000 \\
\hline
\end{tabular}

When we conducted our pre-defined sensitivity analysis, excluding trials at high, or uncertain risk of bias in the key domains of allocation sequence generation, allocation concealment and blinding of outcome assessor, only one trial met the criteria (Walker 2015). In that trial, there was no clear difference in pressure ulcer incidence between the silicone dressing group and the no dressing group (RR $1.95 ; 95 \% \mathrm{Cl} 0.18$ to 20.61 ; silicone dressing: $2 / 39,5 \%$ no dressing group: $1 / 38,3 \%$; low-certainty evidence, downgraded twice for very serious imprecision due to relatively few events leading to a very wide $\mathrm{Cl}$; Analysis 3.2).

\section{Secondary outcomes}

\section{Stage of any pressure ulcers}

Analysis 3.3; Summary of findings 3

Five trials (1004 participants) reported the pressure ulcer stage (Forni 2018; Kalowes 2016; Qiuli 2010; Santamaria 2015; Walker 2015);

It is uncertain whether silicone dressings reduce the incidence of stage 1 and stage 2 pressure ulcers, compared with no dressing (stage 1: silicone 2\%, 8/377; no dressing 9\%, 35/372; RR 0.27; 95\% $\mathrm{Cl} 0.08$ to 0.90 ; very low-certainty evidence, downgraded twice for very serious risk of bias due to high or unclear risk of bias for multiple criteria, specifically selection and detection bias and downgraded twice for serious imprecision due to wide confidence interval; stage 2: silicone $2 \%, 9 / 548$, no dressing 5\%, 26/542; RR $0.40 ; 95 \% \mathrm{Cl} 0.17$ to 0.94 ; very low-certainty evidence downgraded twice for very serious risk of bias due to high or unclear risk of bias for multiple criteria, specifically selection and detection bias and downgraded twice for very serious imprecision due to wide confidence interval). It is uncertain whether silicone dressing results in a difference in pressure ulcer severity, compared with no dressing for other pressure ulcer stages (stage 4 RR $0.20 ; 95 \% \mathrm{Cl}$ 0.01 to 4.13; unstageable, RR $0.20 ; 95 \% \mathrm{Cl} 0.01$ to 4.09; deep tissue injury, RR $0.99 ; 95 \% \mathrm{Cl} 0.06$ to 15.69 ; very low certainty evidence, downgraded twice for high or unclear risk of bias for multiple criteria, specifically selection and detection bias and downgraded twice for very serious imprecision due to very few events and very wide confidence interval. (Figure 6). 
Figure 6. Forest plot of comparison 3 Silicone dressing versus no dressing, outcome: 3.3 Pressure ulcer stage

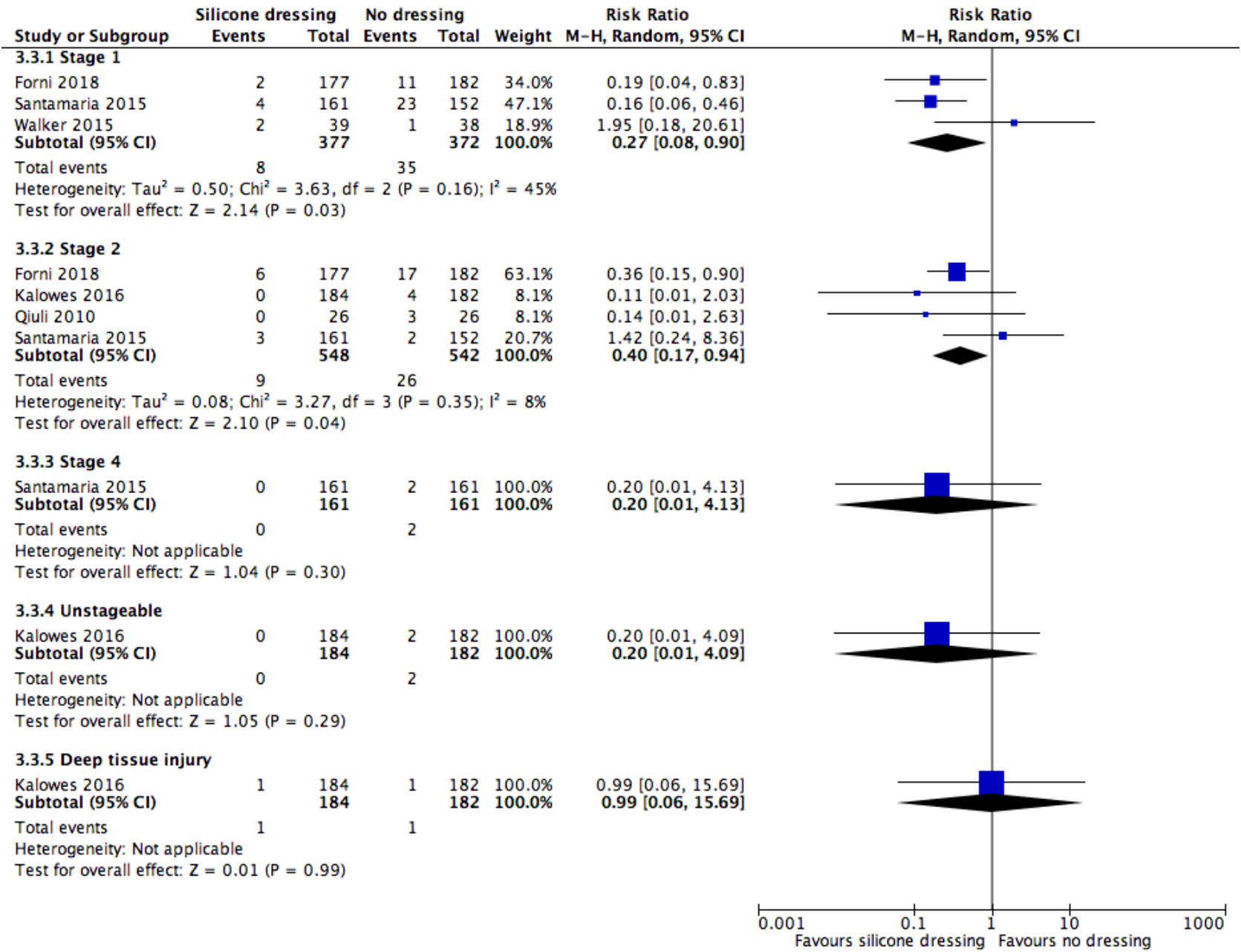

\section{Time to pressure ulcer development}

Kalowes 2016 was the only investigator to report on this outcome. The survival analysis (Cox proportional hazards model) shows that the time to pressure ulcer development was slightly longer in the silicone-dressing group, compared with the no-dressing group (hazard ratio $(\mathrm{HR}) 0.12,95 \% \mathrm{Cl} 0.02$ to 0.98 ; very low-certainty evidence, downgraded twice for high risk of performance and detection bias and downgraded twice serious imprecision due to small number of events resulting in a wide $\mathrm{Cl}$ ) Summary of findings 3.

\section{Cost of intervention}

Santamaria 2015 (see the secondary reference to this trial for costbenefit analysis) provided cost estimates based on an assumption that participants would remain in hospital for 20 days and that costs for treating ulcers would not change during this time. The estimated average cost for the dressing group was AUD 70.82 compared with the no-dressing group of AUD 144.56. Saab 2015 reported that the mean cost of the silicone dressing was USD 16.8 (SD 24.5) per patient stay.

\section{Pain at dressing change (measured by any validated scale)}

None of the trials provided data for this outcome.

\section{Acceptability of/satisfaction with the intervention (with respect to participants' comfort)}

Walker 2015 reported that participants were asked to rate comfort of the dressing on 131 occasions. On six (4.6\%) occasions participants found the dressing uncomfortable. No further analysis was carried out.

\section{Adverse events}

Santamaria 2015 stated that no dressing-related adverse events occurred during the trial. None of the other trials in this group provided adverse event data.

\section{Comparison 4: other dressing versus placebo, control or no dressing (4 trials 449 participants)}

A variety of experimental dressings and controls were included in this comparison (Table 1 ).

\section{Quality of life (measured by any validated scale)}

None of the trials provided data for this outcome. 


\section{Primary outcome}

\section{Pressure ulcer incidence (proportion of participants developing any new pressure ulcer(s) of any stage)}

Analysis 4.1; Summary of findings 4

All trials reported the primary outcome (Dutra 2015; Han 2011; Nakagami 2007; Otero 2017). Although there was no statistical subgroup heterogeneity, we did not combine data due to differences in populations, follow-up periods, and interventions.

Dutra 2015 reported no clear difference in pressure ulcer incidence when comparing a polyurethane film dressing $(7 / 80,9 \%)$ with a hydrocolloid dressing (12/80, 15\%) (RR $0.58,95 \% \mathrm{Cl} 0.24$ to 1.41 ); and Han 2011 also reported no difference comparing a Kang' huier dressing $(2 / 49,4 \%)$ with routine care $(5 / 51,10 \%)$ (RR $0.42,95 \%$ $\mathrm{Cl} 0.08$ to 2.05). We assessed the certainty of the evidence in these trials as very low, downgraded once (Dutra 2015) and twice (Han 2011) for very serious risk of bias, and twice (both trials) for serious imprecision. In the Nakagami 2007 trial no pressure ulcers developed in either arm of the trial, however, the trial authors reported the presence of persistent erythema in both groups. We have interpreted the presence of persistent erythema as a stage 1 pressure ulcer.Nakagami 2007 found no clear difference in pressure ulcer incidence when they compared a PPD dressing (2/37,5\%) with no dressing $(11 / 37,29 \%)$ (RR $0.18,95 \% \mathrm{Cl} 0.04$ to 0.76 ; very lowcertainty evidence, downgraded twice for risk of bias due to high risk of performance, detection and other bias, and downgraded twice for serious imprecision due to small number of events and wide $\mathrm{Cl}$ ). Otero 2017 found no clear difference in the incidence of pressure ulcers, when they compared a thin polyurethane dressing with no dressing (RR $1.31,95 \% \mathrm{Cl} 0.83$ to $2.07 ; 20 / 35,57 \%$ versus $17 / 39,44 \%$; low-certainty evidence, downgraded twice for serious risk of bias due to high risk of performance and attrition bias, and downgraded once for imprecision due to a wide $\mathrm{Cl}$ ). However, when Otero 2017 compared an adhesive foam dressing with no dressing there were more pressure ulcers in the intervention group (RR $1.65 ; 95 \% \mathrm{Cl} 1.10$ to $2.48 ; 28 / 39,72 \%$ versus $17 / 39$, $44 \%$; very low-certainty evidence, downgraded twice for risk of bias due to high risk of performance and attrition bias, and downgraded once for imprecision due to a wide $\mathrm{Cl}$ ).

We did not consider any of the trials at low risk for our pre-defined key domains, so no sensitivity analyses were possible for this comparison.

\section{Secondary outcomes}

\section{Stage of any pressure ulcers}

None of the trials provided data for this outcome.

\section{Time to pressure ulcer development}

None of the trials provided data for this outcome.

\section{Cost of interventions}

None of the trials provided data for this outcome.

\section{Quality of life (measured by any validated scale)}

None of the trials provided data for this outcome.

\section{Pain at dressing change (measured by any validated scale)}

None of the trials provided data for this outcome.

\section{Acceptability of/satisfaction with the intervention (with respect to participants' comfort)}

None of the trials provided data for this outcome.

\section{Adverse events}

None of the trials provided data for this outcome.

\section{DISCUSSION}

\section{Summary of main results}

This systematic review examined the evidence from 18 RCTs with a total of 3629 participants (range 52 to 831 ) that focused on the effects of interventions aimed at reducing the incidence of pressure ulcers. The included studies used two categories of interventions: creams or topical applications applied to the skin; and dressings placed over bony prominences, such as the sacrum and hips. In the first category, five trials investigated fatty acid versus other topical applications (1323 participants); and four trials explored an active topical agent versus placebo (773 participants). In the dressings category, six trials explored a silicone dressing versus no dressing (1247 participants) and four trials explored other dressings versus placebo, control, or no dressing (449 participants). This is the first update of the review, and since first publication the number of eligible trials has doubled, from 9 to 18 .

\section{Topical agents}

\section{Primary outcome: development of new pressure ulcers}

In five trials the intervention was fatty acid, which they compared with olive oil (two trials including 1060 participants); another topical compound (one trial, 331 participants) or standard care (two trials, 187 participants). There is an interest in essential fatty acids because of their suggested role in wound healing (McCusker 2010). However, analysis of the trial data yielded mixed results, for example, where the comparison was olive oil, data from two trials showed no clear difference in the incidence of pressure ulcers. Similarly, when an application of fatty acid was compared with standard care, no clear difference could be demonstrated. Conversely, one trial found fewer pressure ulcers in a group using a compound including fatty acid when compared with those using a compound containing tristostearin and a perfume. We rated evidence for most of the outcomes in these comparisons as low or very low certainty due to serious risk of bias in trial design or imprecision, or both, due mostly to small sample sizes.

Four trials investigated the use of an active topical agent versus placebo. Once again, data analysis yielded mixed results with only one trial (61 participants) finding that DMSO cream may increase the risk of pressure ulcer incidence compared with a placebo treatment; we graded evidence for the trial as low certainty. In the other three trials there were no clear differences in pressure ulcer development between the trial groups.

\section{Secondary outcomes}

There was limited, low-certainty evidence reported in one trial to suggest that the application of a fatty acid compound may delay the development of a new pressure ulcer, but not prevent 
its occurrence. Low-certainty evidence from trials that compared fatty acid with olive oil reported a very low incidence of itchiness or redness. No useful data were reported for any of our other secondary outcomes.

It was also uncertain from evidence in one trial (classified as very low certainty) whether a Contrane cream reduced or increased the risk of higher-stage pressure ulcers compared with a placebo. One trial assessed adverse events. This trial reported more erythematous eruptions in those using Dermalex cream compared with the control group. The evidence for this outcome is very uncertain (based on very low numbers of events).

\section{Summary}

Low- or very low-certainty evidence found that use of a fatty acid compound may reduce the incidence of pressure ulcers compared with a control compound. Use of DMSO cream may increase the incidence of pressure ulcers when compared with a placebo. Evidence for most topical applications remains inconclusive.

\section{Dressings}

\section{Primary outcome: development of new pressure ulcers}

We summarised results from the six trials that used a silicone dressing as the intervention. The main results suggest that use of silicone dressings over bony prominences may reduce the incidence of pressure ulcers. We rated the combined evidence as low certainty for all stages of pressure ulcers (due to serious risk of bias with trial designs) (see Quality of the evidence).

We also reviewed evidence for a number of other dressings that were used to prevent pressure ulcers. In three trials of very lowcertainty evidence (334 participants), there was no clear difference in pressure ulcer incidence in polyurethane film versus hydrocolloid dressing, Kang' huier versus routine care, or PPD dressing versus no dressing.

A further trial (39 participants) compared an adhesive dressing with no dressing. We also assessed the evidence for this trial as low certainty, but found that there may be a difference in the incidence of pressure ulcers, favouring the no-dressing group.

\section{Secondary outcomes}

We assessed data from five trials that included outcomes for higher-stage pressure ulcers (1090 participants). Although all the trials compared silicone dressing with no dressing, we remain uncertain if there is any clinical benefit for silicone dressings for the prevention of any pressure ulcer stage greater than stage 2 . Again, we rated the evidence as very low certainty, due to risk of bias in the trial design of many of the trials and a serious imprecision due to few higher-stage pressure ulcers reported and the small number of participants included in the trials. Consequently, further, independently funded trials are required to assess the usefulness of silicone dressings to prevent stage 1 and other stage pressure ulcers in people who require long-term protection. Only one trial reported information on adverse events, where no adverse events were documented.

\section{Summary}

Silicone dressings may reduce the incidence of pressure ulcers. However the low level of evidence certainty means that additional research is required to confirm these results.

\section{Overall completeness and applicability of evidence}

Most of the trials focused on the primary outcome, development of a new pressure ulcer, in populations of elderly hospitalised or nursing-home patients. While these groups represent many of those at risk of pressure injury, other high-risk groups, such as individuals undergoing prolonged surgical procedures, people with paraplegia and other immobile people also require investigation (Alderden 2011). Dressings and topical interventions for the prevention of pressure ulcers are numerous, but most have never been evaluated using adequately powered RCTs, or in fact, by any type of trial (for example egg white and many skin moisturisers, such as Vaseline and collagenase ointment). Dressings impregnated with honey, iodine and other agents also remain under-investigated (NPUAP/EPUAP/PPPIA 2014). Lack of research funding is perhaps the main impediment to investigations of alternative approaches to pressure ulcer prevention. A problem with the evidence presented in this review is that many of the comparisons include only one trial, with only one head-to-head comparison. We know that effect sizes tend to change as new trials are added but it is unlikely that many of the one-off trials reported here will ever be repeated. The included trials also failed to provide adequate economic evaluations. Healthcare providers need such data to be able to adequately assess the cost/ benefit implications of new interventions. Only one trial mentioned adverse events (Green 1974), and none provided information about other important patient-related outcomes, such as quality of life, pain, length of hospital stay, or acceptability of the product.

\section{Quality of the evidence}

\section{Limitations in trial design and implementation}

We included only RCTs in the review, to reduce any risk of investigators or participants choosing a particular intervention. Even so, the methodological quality of most of the RCTs was poor, with limitations in a number of the 'Risk of bias' domains (Figure 3). For example, in many trials the randomisation process was unclear, outcome assessors were not blinded to the treatment and, in some trials, the attrition rates were high. Short followup times also limited an understanding of the true prophylactic effect of the dressings and topical lotions included in the review. Using the GRADE criteria, we had to downgrade the evidence for outcomes in each of the five comparator groups to low or very low quality. The most frequent reasons for downgrading were for risk of bias and for imprecision. The Nakagami 2007 trial is prone to unit of analysis error, as two sides of each participant were randomised to intervention and control and the Houwing 2008 trial randomised participants by ward, not individual, but did not make any allowance in the analyses for the cluster design.

\section{Indirectness of evidence}

Although the review was limited by variations in both the experimental and the control interventions, we did not downgrade the evidence for indirectness as it covers the population, intervention and outcomes stipulated in the protocol.

\section{Imprecision of results}

Small sample sizes and few events, particularly for higher-stage pressure ulcers, have generated wide confidence intervals in most of the pooled outcomes. Wide confidence intervals represent a high level of uncertainty around the effect size, consequently, 
further research is very likely to have an important impact on the confidence of the estimate of effect for both topical agents and dressings.

\section{Publication bias}

Results from some of the completed trials that we found in our search of clinical trials registries have not been published. Reasons for not publishing are unclear but, if negative results are the cause, failure to include results from negative trials may lead to a spurious positive effect, favouring the intervention.

\section{Potential biases in the review process}

We followed clearly described procedures to prevent potential bias in the review process. This included a careful literature search and the methods we used were transparent and reproducible. Han 2011 was published in Chinese but we were able to extract data with the help of an interpreter. We also attempted to contact all trial authors where additional information was required. Where entries in clinical trials registries indicated that a trial had been completed, we searched for authors' names to try to identify any published report. It should be noted that the results of all trials have not yet been included and as such this is a potential source of bias. None of the trial authors has any conflict of interest. It is possible that trials published in journals that were outside our search strategy may have been missed.

\section{Agreements and disagreements with other studies or reviews}

Although there have been many systematic reviews and trials addressing treatment of pressure ulcers, there has been less attention paid to preventing their occurrence. The prevention reviews that exist have focused on other interventions, such as support surfaces (Mclnnes 2011), risk-assessment tools (Moore 2008), and nutritional interventions (Langer 2003). One overview of pressure ulcer prevention strategies did include topical applications (Reddy 2006). Our results concur with Reddy 2006, who concluded that, "The incremental benefit of specific topical agents over simple moisturizers . . . remains unclear". A further two reviews focused on dressings for preventing pressure ulcers (Clark 2014; Huang 2015) and our results also concur with these authors who conclude that use of dressings as a component of part of pressure ulcer prevention may reduce the incidence of pressure ulcer among at-risk people. We noted that the combined, industryfunded trials were the only group showing an effect favouring the intervention. This finding is in keeping with that of Lundh 2012 and Riaz 2015, who identified that industry-supported trials were more likely to report favourable outcomes when compared with nonindustry-supported trials.

\section{AUTHORS' CONCLUSIONS}

\section{Implications for practice}

Pressure ulcers are a relatively common and important complication of hospitalisation and the application of dressings, creams or other topical agents is used as an intervention to prevent pressure ulcers from forming. When we systematically reviewed the evidence we found no clear benefit or harm for most interventions for which data were available on pressure ulcer incidence. Silicone dressings may reduce any stage pressure ulcer incidence and fatty acids versus a control compound may reduce pressure ulcer incidence. The low level of evidence certainty means that additional research is required to confirm these results.

\section{Implications for research}

The evidence base for use of topical agents and dressings to prevent pressure ulcers is limited, despite the wide use of these interventions. Further trials may be justified given the incidence of the problem and the high costs associated with pressure ulcer management. There are many potential interventions for pressure ulcer prevention and, given the opportunity costs for funding any one study, the decision on future trials also needs to take account of the relative priority of current uncertainties to patients and other decisions makers in the areas. Where trials on dressings and topical agents are pursued, trialists should consider evaluation of products that have a theoretical underpinning, which suggests an ability to dissipate pressure and shear from tissues. Further, future trials should be large enough to show meaningful differences; include patient-related outcomes, such as product acceptability, adverse events and quality of life, and economic evaluations to assist healthcare managers to make rational decisions. Standard, validated tools should be used to measure outcomes such as pressure ulcer staging, and quality of life.

\section{ACKNOWLEDGEMENTS}

The authors would like to acknowledge the contribution of peer reviewers Gill Norman (Editor) and Victoria Steelman, who offered feedback on this review update; and to David Brienza, Carol Dealey, Rachel Richardson, Durhane Wong-Rieger, Marian Brady, David Margolis and Gill Worthy, who commented on previous versions of the review. They also offer thanks to copy-editor Jenny Bellorini who edited the original review and Denise Mitchell who edited this updated version. 


\section{R E F E R E N C E S}

\section{References to studies included in this review}

Chiew 2010 \{published data only\}

Chiew SF, Liu HJ, Toh HT, Dari R. Does sanyrene solution reduce incidence of pressure ulcer among the elderly with hip fracture? A randomised controlled trial. Proceedings of Singapore Healthcare 2010;19(2 (Suppl)):S154.

\section{Diaz-Valenzuela 2014 \{published data only\}}

Diaz-Valenzuela A, Valle Canete MJ, Carmona Fernandez PJ, Garcia-Fernandez FP, Pancorbo-Hidalgo PL. Efficacy for preventing pressure ulcers of the virgin extra olive oil versus hyper-oxygenated fatty acids: intermediate results from a non-inferiority trial [Eficacia en la prevención de úlceras por presión del aceite de oliva virgen extra frente a los ácidos grasos hiperoxigenados: resultados intermedios de un estudio de no inferioridad]. Gerokomos 2014;25(2):74-80.

\section{Dutra 2015 \{published data only\}}

Dutra RA, Salome GM, Alves JR, Pereira VO, Miranda FD, Vallim VB, et al. Using transparent polyurethane film and hydrocolloid dressings to prevent pressure ulcers. Journal of Wound Care 2015;24(6):268, 270-1, 273-5.

\section{Forni 2018 \{unpublished data only\}}

Forni C. Effectiveness of using a new polyurethane foam multilayer dressing in the sacral area to prevent the onset of pressure ulcer in the elderly with hip fractures: a pragmatic randomised controlled trial. International Wound Journal 2018; Vol. 04.

\section{Green 1974 \{published data only\}}

Green MF, Exton-Smith AN, Helps EP, Kataria MS, Wedgewood J, Williams TP. Prophylaxis of pressure sores using a new lotion. Modern Geriatrics 1974;4(9):376-84.

Han 2011 \{published data only\}

Han J, Li G, Wang A. Control study on pressure sore prevention for patients accepting posterior spinal surgery. Chinese Nursing Research 2011;25:308-10.

\section{Houwing 2008 \{published data only\}}

Houwing R, Van der Zwet W, Van Asbeck S, Halfens R, Arends JW. An unexpected detrimental effect on the incidence of heel pressure ulcers after local 5\% DMSO cream application: a randomized, double-blind study in patients at risk for pressure ulcers. Wounds 2008;20(4):84-8.

\section{Kalowes 2016 \{published data only\}}

Kalowes P, Messina V, Li M. Five-layered soft foam dressing to prevent pressure ulcers in the intensive care unit. American Journal of Critical Care 2016;25:e108-e119.

\section{Lupianez-Perez 2015 \{published data only\}}

Lupianez-Perez I, Uttumchandani SK, Morilla-Herrera JC, Martin-Santos FJ, Fernandez-Gallego MC, Navarro-Moya FJ. Topical olive oil is not inferior to hyperoxygenated fatty aids to prevent pressure ulcers in high-risk immobilised patients in home care. Results of a multicentre randomised triple-blind controlled non-inferiority trial. PLOS ONE 2015;10(4):e0122238.
Nakagami 2007 \{published data only\}

Nakagami G, Sanada H, Konya C, Kitagawa A, Tadaka E, Matsuyama Y. Evaluation of a new pressure ulcer preventive dressing containing ceramide 2 with low frictional outer layer. Journal of Advanced Nursing 2007;59(5):520-9.

Otero 2017 \{published data only\}

Otero DP, Domínguez DV, Fernández LH, Magariño AS, González VJ, Klepzing JV, et al. Preventing facial pressure ulcers in patients under non-invasive mechanical ventilation: a randomised control trial. Journal of Wound Care 2017;26(3):128-36.

\section{Qiuli 2010 \{published data only\}}

Qiuli B, Qiongyu J. Observation on effect of Mepilex on the prevention and treatment of pressure sores. Department of Neurosurgery, The Second Affiliated Hospital of Harbin Medical University 2010.

\section{Saab 2015 \{published data only\}}

Saab I, Solomon JF, Allen L, Siddiqui A. Hydrocellular foam is a cost-effective dressing for preventing pressure ulcers: a randomized controlled study. Journal of the American College of Surgeons 2015;221(4 (1 Suppl)):S114.

Santamaria 2015 \{published data only\}

* Santamaria N, Gerdtz M, Sage S, McCann J, Freeman A, Vassiliou T, et al. A randomised controlled trial of the effectiveness of soft silicone multi-layered foam dressings in the prevention of sacral and heel pressure ulcers in trauma and critically ill patients: the Border Trial. International Wound Journal 2015;12(3):302-8. [DOI: 10.1111/iwj.12101]

Santamaria N, Liu W, Gerdtz M, Sage S, Mccann J, Freeman A, et al. The cost-benefit of using soft silicone multilayered foam dressings to prevent sacral and heel pressure ulcers in trauma and critically ill patients: a within-trial analysis of the Border Trial. International Wound Journal 2015;12(3):344-50. [DOI: 10.1111/iwj.12160]

\section{Smith 1985 \{published data only\}}

Smith RG, Everett E, Tucker L. A double blind trial of silicone barrier cream in the prevention of pressure sores in elderly patients. Journal of Experimental Gerontology 1985;7(4):337-46.

Torra i Bou 2005 \{published data only\}

Torra i Bou J, Gomez TS, Soriano JV, Bonmati AN, Lopez JR, Arboix i Perejamo M. The effectiveness of a hyper-oxygenated fatty acid compound in preventing pressure ulcers. Journal of Wound Care 2005;14(3):117-21.

\section{Van Der Cammen 1987 \{published data only\}}

Van Der Cammen TJ, O'Callaghan U, Whitefield M. Prevention of pressure sores: a comparison of new and old pressure sore treatments. British Journal of Clinical Practice 1987;41(11):1009-11. 
Walker 2015 \{published data only\}

Walker R, Aitken LM, Huxley L, Juttner M. Prophylactic dressing to minimize sacral pressure injuries in high-risk hospitalized patients: a pilot study. Journal of Advanced Nursing 2015;71(3):688-96. [DOI: 10.1111/jan.12543]

\section{References to studies excluded from this review}

\section{Alvarez Vázquez 2014 \{published data only\}}

Alvarez Vázquez JC, Estany Gestal A, Álvarez Suárez T, Mosquera J, Castro Prado J, Gutiérrez Moeda E, et al. Prevention of deterioration of the cutaneous integrity in the sacral area through the application of an atraumatic self-adherent foam dressing. Metas de Enfermería 2014;17(2):14-20.

\section{Callaghan 1998 \{published data only\}}

Callaghan S, Trapp M. Evaluating two dressings for the prevention of nasal bridge pressure sores. Professional Nurse 1998;13(6):361-4.

\section{Declaire 1997 \{published data only\}}

Declaire V. The usefulness of topical application of essential fatty acids (EFA) to prevent pressure ulcers. Ostomy/Wound Management 1997;43(5):48-54.

\section{Duimel-Peeters 2007 \{published data only\}}

Duimel-Peeters IG, Halfensa RJ, Ambergen AW, Houwing RH, Berger MP, Luc HE, et al. The effectiveness of massage with and without dimethyl sulfoxide in preventing pressure ulcers: a randomized, double-blind cross-over trial in patients prone to pressure ulcers. International Journal of Nursing Studies 2007;44(8):1285-95.

\section{Garcia Fernandez 2005 \{published data only\}}

Garcia Fernandez FP, Pancorbo Hidalgo PL, Rodriguez Torres MC. Protective bandage or hydrocellular dressing to prevent pressure ulcers on heels?. Gerokomos 2005;16(1):54-8.

Hsu 2011 \{published data only\}

Hsu MY, Hsiu SR, Chung HC, Chang SC, Tang M, Tai CH. Evaluating dressings for the prevention of facial pressure ulcers caused by the application of noninvasive positive pressure ventilation: a pilot study. EWMA Journal 2011;11(Suppl):213.

\section{Huang 2009 \{published data only\}}

Huang TT, Tseng CE, Lee TM, Yeh JY, Lai YY. Preventing pressure sores of the nasal ala after nasotracheal tube intubation: from animal model to clinical application. Journal of Oral and Maxillofacial Surgery 2009;67(3):543-51.

\section{Kalowes 2013 \{published data only\}}

Kalowes P, Li M, Carlson C, Carr L, Llantero L, Lukaszka D, et al. Use of a silicone border sacrum dressing to reduce pressure ulcer formation in critically ill patients: a randomized clinical trial. EWMA Journal 2013;13(1 Suppl):63. [Abstract 88]

\section{Kuisma 1987 \{published data only\}}

Kuisma I, Tamelander G. Mucopolysaccharide polysulphate cream in the prevention of pressure sores-a double blind study. Annals of Clinical Research 1987;19(6):374-7.
Park 2014a \{published data only\}

Park KH. The effect of a silicone border foam dressing for prevention of pressure ulcers and incontinence-associated dermatitis in intensive care unit patients. Journal of Wound, Ostomy, and Continence Nursing 2014;41(5):424-9.

Park 2014b \{published data only\}

Park KH. The effect of a ceramide-containing dressing in preventing pressure ulcers. Journal of Wound Care 2014;23(7):347-53. [DOI: http://dx.doi.org/10.12968/ jowc.2014.23.7.347]

\section{Santamaria 2013 \{published data only\}}

Santamaria N, Gerdtz M, Vassiliou T, Knott J, DeVincentis S, Sage $S$, et al. The border trial: a prospective randomised controlled trial of the effectiveness of multi-layer silicone dressings in preventing intensive care unit pressure ulcers. EWMA Journal 2013;13(1 Suppl):93. [Abstract 147]

Smith 2010 \{published data only\}

Smith G, Ingram A. Clinical and cost effectiveness evaluation of low friction and shear garments. Journal of Wound Care 2010;19(12):535-42.

\section{Stoker 1990 \{published data only\}}

Stoker FM. A major contributor. Evaluation of Comfeel pressure relieving dressing. Professional Nurse 1990;5(12):644-53.

Torra i Bou 2009 \{published data only\}

Torra i Bou JE, Narváez EH, Martinez-Esparza EH, Segovia Gómez T, López JR, Blanco Blanco J, et al. Preventing pressure ulcers on the heel: a Canadian cost study. Dermatology Nursing 2009;21(5):268-72.

\section{Wen-Yi 2013 \{published data only\}}

Wen-Yi T, Shu-Fen L, Harmod T, Ru-Ping L. A comparison of the efficacy of different wound dressing management techniques in preventing pressure ulcers. Journal of Nursing (Zhonghua Hu $\mathrm{Li}$ Za Zhi) 2013;60(4):65-75. [DOI: 10.6224/JN.60.4.65]

\section{References to studies awaiting assessment}

Aloweni 2017 \{published data only\}

Aloweni F, Lim ML, Chua TL, Tan SB, Lia SB, Ang SY. A randomised controlled trial to evaluate the incremental effectiveness of a prophylactic dressing and fatty acids oil in the prevention of pressure injuries. Wound Practice and Research: Journal of the Australian Wound Management Association 2017;25(1):24-34.

\section{Guo 2015 \{published data only\}}

Guo H. Effect comparison of nursing of foam dressing in prevention of pressure sores in patients with preoperative and postoperative ambulatory surgery in the department of orthopedics. Chinese Community Doctors 2015;31(34):130-1.

Imbulana 2018 \{published data only\}

Imbulana DI, Owen LS, Dawson JA, Davis PG, Manley BJ. The pronose study: a randomised controlled trial of a nasal barrier dressing to reduce injury in preterm infants receiving binasal 
non-invasive respiratory support. Journal of Paediatrics and Child Health 2018;54(Suppl 1):82-3.

Kim 2016 \{published data only\}

Kim H, Lee SM, Choi HY, Jung YJ. Prophylactic effect of transparent film dressing on sacrum and coccyx in SICU patients. Journal of Korean Academy of Fundamentals of Nursing 2016;23(3):256-63.

\section{Tai 2016 \{published data only\}}

Tai $\mathrm{CH}$, Hsu MY. Preventing facial pressure injuries in patients who use noninvasive positive pressure ventilators: the efficiency of dressings. Hu Li Za Zhi [Chinese Journal of Nursing] 2016;63(5):86-94.

\section{Wang 2016 \{published data only\}}

Wang L, Zhao Y, Ma J. Effect of prevention of adhesive dressing (ALLEVYN) to use of noninvasive ventilator caused by pressure ulcers. Chest 2016;1:A161.

\section{References to ongoing studies}

JPRN-UMIN000024609 \{published data only\}

JPRN-UMIN000024609. Prevention effect of wound dressings for pressure sores in high-risk patients. www.who.int/trialsearch/ Trial2.aspx?TrialID=JPRN-UMIN000024609 (first received 28 October 2016).

\section{NCT01640418 \{unpublished data only\}}

NCT01640418. Prevention of sacral pressure ulcers with preventive dressings (SACRESS). clinicaltrials.gov/ct2/show/ NCT01640418 (first received 11 July 2012).

\section{NCT02295735 \{unpublished data only\}}

NCT02295735. Effectiveness of two silicone dressings for sacral and heel pressure ulcer prevention. clinicaltrials.gov/ct2/show/ NCT02295735 (first received 10 November 2014).

\section{NCT02565745 \{unpublished data only\}}

NCT02565745. Impact of the use of dressings versus lubrication of the skin with cream to prevent pressure ulcers: clinical trial (PENFUP). clinicaltrials.gov/ct2/show/NCT02565745 (first received 29 September 2015).

\section{NCT03039179 \{published data only\}}

NCT03039179. Polyurethane foam on the heel for prevention in children (SCHIUMABIMB). clinicaltrials.gov/ct2/keydates/ NCT03039179 (first received January 31st 2017).

\section{RBR-4s8qjx \{published data only\}}

RBR-4s8qjx. Effect of soft silicone foam dressing compared to film transparent dressing in pressure ulcer prevention. www.who.int/trialsearch/Trial2.aspx?TrialID=RBR-4s8qjx (first received 31 August 2017).

\section{Additional references}

\section{Alderden 2011}

Alderden J, Whitney JD, Taylor SM, Zaratkiewicz S. Risk profile characteristics associated with outcomes of hospital-acquired pressure ulcers: a retrospective review. Critical Care Nurse 2011;31(4):30-43.

\section{Bader 1990}

Bader DL. Effects of compressive loading regimens on tissue viability. In: Bader DL editor(s). Pressure Sores: Clinical Practice and Scientific Approach. London: MacMillan, 1990:191-201.

\section{Barbarel 1977}

Barbarel JC, Jordan MM, Nicol SM, Clark MO. Incidence of pressure sores in the greater Glasgow Health Board area. Lancet 1977;2(8037):548-50.

\section{Bergstrom 1987}

Bergstrom N, Braden BJ, Laguzza A, Holman V. The Braden Scale for predicting pressure sore risk. Nursing Research 1987;36(4):205-10.

\section{Black 2007}

Black J, Baharestani M, Cuddigan J, Dorner B, Edsberg L, Langemo D, et al. National Pressure Ulcer Advisory Panel's updated pressure ulcer staging system. Dermatology Nursing 2007;19(4):343-9.

\section{BNF 2017}

Royal Pharmaceutical Society. British National Formulary. www.evidence.nhs.uk/formulary/bnf/current/a5-woundmanagement-products-and-elasticated-garments (accessed 25 January 2017).

\section{Brown 2003}

Brown G. Long-term outcomes of full-thickness pressure ulcers: healing and mortality. Ostomy/Wound Management 2003;49(10):42-50

\section{Butcher 2009}

Butcher M, Thompson G. Dressings can prevent pressure ulcers: fact or fallacy? The problem of pressure ulcer prevention. Wounds UK 2009;5(4):80-93.

\section{Call 2015}

Call E, Pedersen J, Bill B, Black J, Alves P, Brindle CT, et al. Enhancing pressure ulcer prevention using wound dressings: what are the modes of action?. International Wound Journal 2015;12:408-13.

\section{Clark 2014}

Clark M, Black J, Alves P, Brindle C, Call E, Dealey C, et al. Systematic review of the use of prophylactic dressings in the prevention of pressure ulcers. International Wound Journal 2014;11(5):460-71.

\section{Collier 2006}

Collier M, Moore Z. Pressure ulcer aetiology and risk factors. In: Romanelli M, Clark M, Cherry G, Colin D, Defloor T editor(s). Science and Practice of Pressure Ulcers. London: SpringerVerlag, 2006:27-36.

\section{Dealey 2012}

Dealey C, Posnett J, Walker A. The cost of pressure ulcers in the United Kingdom. Journal of Wound Care 2012;21(6):261-6. 


\section{Deeks 2011}

Deeks JJ, Higgins JP, Altman DG, on behalf of the Cochrane Statistical Methods Group and the Cochrane Bias Methods Group. Chapter 9: Analysing data and undertaking metaanalysis. In: Higgins JP, Green S, editor(s). Cochrane Handbook for Systematic Reviews of Interventions Version 5.1.0 (updated March 2011). The Cochrane Collaboration, 2011. Available from handbook.cochrane.org.

\section{Demarre 2015}

Demarre L, Van Lancker A, Van Hecke A, Verhaeghe S, Grypdonck M, Lemey J, et al. The cost of prevention and treatment of pressure ulcers: a systematic review. International Journal of Nursing Studies 2015;52:1754-74.

\section{EPUAP 1999}

European Pressure Ulcer Advisory Panel (EPUAP). Guidelines on treatment of pressure ulcers. EPUAP Review 1999;2:31-3.

\section{Gallagher 2008}

Gallagher P, Barry P, Hartigan I, McCluskey P, O'Connor K, O'Connor M. Prevalence of pressure ulcers in three university teaching hospitals in Ireland. Journal of Tissue Viability 2008;17(4):103-9.

\section{García-Fernández 2014}

García-Fernández FP, Soldevilla Ágreda JJ, Pancorbo Hidalgo PL, Verdú Soriano J, López-Casanova P, RodríguezPalma M. Classification/categorisation of dependencerelated lesions [Clasificación-categorización de las lesiones relacionadas con la dependencia]. Serie Documentos Técnicos GNEAUPP no.II. 2nd Edition. Logroño, Spain: Grupo Nacional para el Estudio y Asesoramiento en Úlceras Por Presión y Heridas Crónicas, 2014

\section{Gefen 2017}

Gefen A. Why is the heel particularly vulnerable to pressure ulcers?. British Journal of Nursing 2017;26:S62-S74.

\section{Gibbons 2006}

Gibbons W, Shanks HT, Kleinhelter P, Jones P. Clinical excellence series. Eliminating facility-acquired pressure ulcers at Ascension Health. Joint Commission Journal on Quality \& Patient Safety 2006;32(9):488-96.

\section{Gorecki 2009}

Gorecki C, Brown JM, Nelson EA, Briggs M, Schoonhoven L, Dealey $C$, et al. Impact of pressure ulcers on quality of life in older patients: a systematic review. Journal of the American Geriatrics Society 2009;57(7):1175-83.

\section{Gorecki 2012}

Gorecki C, Nixon J, Madill A, Firth J, Brown JM. What influences the impact of pressure ulcers on health-related quality of life? A qualitative patient-focused exploration of contributory factors. Journal of Tissue Viability 2012;21:3-12.

\section{GRADEpro GDT 2015 [Computer program]}

McMaster University (developed by Evidence Prime). GRADEpro GDT. Version accessed 20 July 2018. Hamilton (ON): McMaster University (developed by Evidence Prime), 2015.

\section{Graves 2005}

Graves N, Birrell FA, Whitby M. Modelling the economic losses from pressure ulcers among hospitalized patients in Australia. Wound Repair and Regeneration 2005;13(5):462-7.

\section{Guest 2015}

Guest JF, Ayoub N, Mcllwraith T, Uchecbu I, Gerrish A, Weidlich $D$, et al. Health economic burden that wounds impose on the National Health Service in the UK. BMJ Open 2015;5:e009283.

\section{Haalboom 2000}

Haalboom JR. Some remarks about overlays in the prevention and treatment of pressure ulcers. EPUAP Review 2000;2:67-70.

\section{Higgins 2003}

Higgins JP, Thompson SG, Deeks JJ, Altman DG. Measuring inconsistencies in meta-analysis. BMJ 2003;327(7414):557-60.

\section{Higgins 2011a}

Higgins JPT, Green S (editors). Cochrane Handbook for Systematic Reviews of Interventions Version 5.1.0 (updated March 2011). The Cochrane Collaboration, 2011. Available from handbook.cochrane.org.

\section{Higgins 2011b}

Higgins JP, Altman DG, on behalf of the Cochrane Statistical Methods Group and the Cochrane Bias Methods Group. Chapter 8: Assessing risk of bias in included studies. In: Higgins JP, Green S, editor(s). Cochrane Handbook for Systematic Reviews of Interventions Version 5.1.0 (updated March 2011). The Cochrane Collaboration, 2011. Available from handbook.cochrane.org.

\section{Higgins 2011c}

Higgins JP, Deeks JJ, Altman DG, on behalf of the Cochrane Statistical Methods Group. Chapter 16: Special topics in statistics. In: Higgins JP, Green S, editor(s). Cochrane Handbook for Systematic Reviews of Interventions Version 5.1.0 (updated March 2011). The Cochrane Collaboration, 2011. Available from handbook.cochrane.org.

\section{Hopkins 2006}

Hopkins A, Dealey C, Bale S, Defloor T, Worboys F. Patient stories of living with a pressure ulcer. Journal of Advanced Nursing 2006;56(4):345-53.

\section{Huang 2015}

Huang L, Woo KY, Liu LB, Wen RJ, Hu AL, Shi CG. Dressings for preventing pressure ulcers: a meta-analysis. Advances in Skin and Wound Care 2015;28(6):267-73.

\section{International Review 2010}

International Review. Pressure ulcer prevention: pressure, shear, friction and microclimate in context. A consensus document. www.woundsinternational.com/media/issues/300/ files/content_8925.pdf (accessed 25 January 2017).

\section{Jenkins 2010}

Jenkins ML, O'Neal E. Pressure ulcer prevalence and incidence in acute care. Advances in Skin and Wound Care 2101;23:556-9. 


\section{Khor 2014}

Khor HM, Tan J, Saedon NI, Kamaruzzaman SB, Chin AV, Poi PJ, et al. Determinants of mortality among older adults with pressure ulcers. Archives of Gerontology and Geriatrics 2014;59:536-41.

\section{Kosiak 1959}

Kosiak M. Etiology and pathology of ischaemic ulcers. Archives of Physical Medicine and Rehabilitation 1959;40(2):62-9.

\section{Kottner 2009}

Kottner J, Balzer K, Dassen T, Heinze S. Pressure ulcers: a critical review of definitions and classifications. Ostomy/Wound Management 2009;55(9):22-9.

\section{Kröger 2008}

Kröger K, Niebel W, Maier I, Stausberg J, Gerber V, Schwarzkopf A. Prevalence of pressure ulcers in hospitalized patients in Germany in 2005: data from the Federal Statistical Office. Gerontology 2008;55(3):281-7.

\section{Lahmann 2011}

Lahmann NA, Kottner J. Relation between pressure, friction and pressure ulcer categories: a secondary data analysis of hospital patients using CHAID methods. International Journal of Nursing Studies 2011;48(12):1487-94.

\section{Langer 2003}

Langer G, Knerr A, Kuss O, Behrens J, Schlömer GJ. Nutritional interventions for preventing and treating pressure ulcers. Cochrane Database of Systematic Reviews 2003, Issue 4. [DOI: 10.1002/14651858.CD003216]

\section{Lefebvre 2011}

Lefebvre C, Manheimer E, Glanville J, on behalf of the Cochrane Information Retrieval Methods Group. Chapter 6: Searching for studies. In: Higgins JP, Green S, editor(s). Cochrane Handbook for Systematic Reviews of Interventions Version 5.1.0 (updated March 2011). The Cochrane Collaboration, 2011. Available from handbook.cochrane.org.

\section{Levy 2015}

Levy A, Frank MB, Gefen A. The biomechanical efficacy of dressings in preventing heel ulcers. Journal of Tissue Viability 2015;24:1-11.

\section{Liberati 2009}

Liberati A, Altman DG, Tetzlaff J, Mulrow C, Gotzsche PC, Ioannidis JP, et al. The PRISMA statement for reporting systematic reviews and meta-analyses of studies that evaluate health care interventions: explanation and elaboration. PLOS Medicine 2009; Vol. 6:e1000100.

\section{Lundh 2012}

Lundh A, Sismondo S, Lexchin J, Busuioc OA, Bero L. Industry sponsorship and research outcome. Cochrane Database of Systematic Reviews 2012, Issue 12. [DOI: 10.1002/14651858.MR000033.pub2]

\section{McCusker 2010}

McCusker MM, Grant-Kels JM. Healing fats of the skin: the structural and immunologic roles of the omega- 6 and omega-3 fatty acids. Clinical Dermatology 2010;28(4):440-51.

\section{McInnes 2011}

McInnes E, Jammali-Blasi A, Bell-Syer SE, Dumville JC, Cullum N. Support surfaces for pressure ulcer prevention. Cochrane Database of Systematic Reviews 2011, Issue 4. [DOI: 10.1002/14651858.CD001735.pub4]

\section{Meuleneire 2013}

Meuleneire F, Rücknagel $\mathrm{H}$. Soft silicones made easy. Wounds International 2013; Vol. Available from: www.woundsinternational.com:Accessed 4 January 2018.

\section{Moore 2006}

Moore Z. Current issues in wound management. Irish Pharmacy Journal 2006; January:25-9.

\section{Moore 2008}

Moore ZE, Cowman S. Risk assessment tools for the prevention of pressure ulcers. Cochrane Database of Systematic Reviews 2008, Issue 3. [DOI: 10.1002/14651858.CD006471.pub2]

\section{Moore 2011b}

Moore Z, Cowman S, Conroy RM. A randomised controlled clinical trial of repositioning, using the $30^{\circ}$ tilt, for the prevention of pressure ulcers. Journal of Clinical Nursing 2011;20(17-18):2633-44.

\section{Moore 2012}

Moore Z, Cowman S. Pressure ulcer prevalence and prevention practices in care of the older person in the Republic of Ireland. Journal of Clinical Nursing 2012;21:362-71.

\section{Moore 2013b}

Moore Z, Johansen E, Van Etten M. A review of PU prevalence and incidence across Scandinavia, Iceland and Ireland (Part I). Journal of Wound Care 2013;22:1-7.

\section{Nixon 2005}

Nixon J, Cranny G, Bond S. Pathology, diagnosis, and classification of pressure ulcers: comparing clinical and imaging techniques. Wound Repair and Regeneration 2005;13(4):365-72.

\section{Norton 1975}

Norton D, McLaren R, Exton-Smith AN. An Investigation of Geriatric Nursing Problems in Hospital. 2nd Edition. New York: Churchill Livingstone, 1975.

\section{NPUAP/EPUAP/PPPIA 2014}

National Pressure Ulcer Advisory Panel (NPUAP), European Pressure Ulcer Advisory Panel (EPUAP), Pan Pacific Pressure Injury Alliance (PPPIA). Prevention and treatment of pressure ulcers: quick reference guide. October 2014. www.npuap.org/ wp-content/uploads/2014/08/Quick-Reference-Guide-DIGITALNPUAP-EPUAP-PPPIA-Jan2016.pdf (accessed 25 January 2017). 


\section{O'Callaghan 2007}

O Callaghan M, Reilly S, Seery A. Pressure. Exploring Science. Dublin: Education Company, 2007:270-7.

\section{Oomens 2015}

Oomens CJ, Bader D, Loerakker S, Baaljens F. Pressure induced deep tissue injury explained. Annals of Biomedical Engineering 2015;43:297-305.

\section{Reddy 1981}

Reddy NP, Cochran GV, Krouskop TA. Interstitial fluid flow as a factor in decubitus ulcer formation. Journal of Biomechanics 1981;14(12):879-81.

\section{Reddy 2006}

Reddy M, Gill SS, Rochon PA. Preventing pressure ulcers: a systematic review. JAMA 2006;296(8):974-84.

\section{RevMan 2014 [Computer program]}

Nordic Cochrane Centre, The Cochrane Collaboration. Review Manager 5 (RevMan 5). Version 5.3. Copenhagen: Nordic Cochrane Centre, The Cochrane Collaboration, 2014.

\section{Riaz 2015}

Riaz H, Raza S, Khan MS, Riaz IB, Krasuski RA. Impact of funding source on clinical trial results including cardiovascular outcome trials. American Journal of Cardiology 2015;15:1944-7.

\section{Russo 2006}

Russo C, Steiner C, Spector W. Hospitalizations related to pressure ulcers among adults 18 years and older, 2006. Healthcare Cost and Utilization Project (HCUP). Statistical Brief \#64. www.hcup-us.ahrq.gov/reports/statbriefs/sb64.pdf (accessed 25 January 2017).

\section{Ryan 2016}

Ryan R, Hill S. How to GRADE the quality of the evidence. Cochrane Consumers and Communication Group. Version 3.0 December 2016. available at http://cccrg.cochrane.org/authorresources.

\section{Schünemann 2011a}

Schünemann HJ, Oxman AD, Higgins JP, Vist GE, Glasziou P, Guyatt GH. Chapter 11: Presenting results and 'Summary of findings' tables. In: Higgins JP, Green S, editor(s). Cochrane Handbook for Systematic Reviews of Interventions Version 5.1.0 (updated March 2011). The Cochrane Collaboration, 2011. Available from handbook.cochrane.org.

\section{Schünemann 2011b}

Schünemann HJ, Oxman AD, Vist GE, Higgins JP, Deeks JJ, Glasziou P. Chapter 12: Interpreting results and drawing conclusions. In: Higgins JP, Green S, editor(s). Cochrane Handbook for Systematic Reviews of Interventions Version 5.1.0 (updated March 2011). The Cochrane Collaboration, 2011. Available from handbook.cochrane.org.

\section{Sheerin 2005}

Sheerin F, Gillick A, Doyle B. Pressure ulcers and spinal-cord injury: incidence among admissions to the Irish national specialist unit. Journal of Wound Care 2005;14(3):112-5.

\section{SIGN 2017}

Scottish Intercollegiate Guidelines Network (SIGN). Search filters. www.sign.ac.uk/search-filters.html (accessed 30 October 2017).

\section{Spilsbury 2007}

Spilsbury K, Nelson A, Cullum N, Iglesias C, Nixon J, Mason S. Pressure ulcers and their treatment and effects on quality of life: hospital inpatient perspectives. Journal of Advanced Nursing 2007;57(5):494-504.

\section{Stekelenburg 2007}

Stekelenburg A, Strijkers GJ, Parusel H, Bader DL, Nicolay K, Oomens CW. Role of ischemia and deformation in the onset of compression-induced deep tissue injury: MRI-based studies in a rat model. Journal of Applied Physiology 2007;102(5):2002-11.

\section{Sullivan 2013}

Sullivan N, Schoelles KM. Preventing in-facility pressure ulcers as a patient safety strategy: a systematic review. Annals of Internal Medicine 2013;158:410-6.

\section{Surgical Materials Testing Lab 2007}

Surgical Materials Testing Lab 2007. Alphabetical list of dressings data cards. www.dressings.org/dressings-datacardsby-alpha.html (accessed 25 January 2017).

\section{Tarnowski Goodell 2013}

Tarnowski Goodell T, Moskovitz Z. Characteristics of hospitalised US veterans with nosocomial pressure ulcers. International Wound Journal 2013;10:44-51.

\section{Thomas 1996}

Thomas DR, Goode PS, Tarquine PH, Allman RM. Hospitalacquired pressure ulcers and risk of death. Journal of the American Geriatric Society 1996;44:1435-40.

\section{Tsuji 2005}

Tsuji S, Ichioka S, Sekiya N, Nakatsuka T. Analysis of ischemiareperfusion injury in a microcirculatory model of pressure ulcers. Wound Repair and Regeneration 2005;13(2):209-15.

\section{Vanderwee 2009}

Vanderwee K, Grypdonck M, De Bacquer D, Defloor T. The identification of older nursing home residents vulnerable for deterioration of grade 1 pressure ulcers. Journal of Clinical Nursing 2009;18(21):3050-8.

\section{Wann-Hansson 2008}

Wann-Hansson C, Hagell P, Willman A. Risk factors and prevention among patients with hospital-acquired and preexisting pressure ulcers in an acute care hospital. Journal of Clinical Nursing 2008;17:1718-27.

\section{Waterlow 1985}

Waterlow J. A risk assessment card. Nursing Times 1985;81(48):49-55. 


\section{References to other published versions of this review}

\section{Moore 2011a}

Moore Z, Webster J. Dressings and topical agents for preventing pressure ulcers. Cochrane Database of Systematic Reviews 2011, Issue 8. [DOI: 10.1002/14651858.CD009362]

\section{CHARACTERISTICS OF STUDIES}

Characteristics of included studies [ordered by study ID]

\section{Moore 2013a}

Moore ZE, Webster J. Dressings and topical agents for preventing pressure ulcers. Cochrane Database of Systematic Reviews 2013, Issue 8. [DOI: 10.1002/14651858.CD009362.pub2]

* Indicates the major publication for the study

Chiew 2010

\begin{tabular}{ll}
\hline Methods & Trial design: RCT \\
Trial grouping: parallel \\
Ethics and informed consent: not reported \\
Follow-up period: not reported \\
Sample size estimate: not reported \\
ITT analysis: yes; number randomised 109: number analysed:109 \\
Funding: not reported \\
Country: Singapore \\
Setting: orthopaedic ward \\
Number: 109 (intervention group 54 participants); (control group: 55 participants) \\
Inclusion criteria: people $>60$ (mean age not reported by group), with traumatic hip fractures who \\
had surgical intervention \\
Exclusion criteria: not stated \\
Pretreatment: most of the participants were female (71.6\%), 76 years old and above (58.7\%), and com- \\
munity ambulant (57.8\%) prior to the hip fracture
\end{tabular}

Interventions

Intervention group: Sanyrene ${ }^{\circledR}$ solution and 2-3 hourly change of position. The topical agent was applied on the patient's sacrum, buttocks and heels at every change of position from day of admission

Control group: 2-3 hourly change of position only

Primary outcome:
PU incidence
- Outcome type: dichotomous outcome
- Reporting: fully reported
- Unit of measure: numbers
- Direction: lower is better
- Data value: endpoint
Secondary outcomes:
Stage of PUs
- Outcome type: dichotomous outcome
- Reporting: partially reported
- Unit of measure: numbers
- Direction: lower stage is better


Chiew 2010 (Continued)

Location of PUs

- Outcome type: dichotomous outcome

- Reporting: partially reported

- Unit of measure: numbers

- Direction: none

- Data value: endpoint

\begin{tabular}{ll}
\hline Identification & Author's name: Chiew SF \\
Institution: Department of Orthopaedic Surgery, Singapore General Hospital, Singapore \\
Email: not stated
\end{tabular}

Address: not stated

\section{Notes}

\section{Risk of bias}

\begin{tabular}{|c|c|c|}
\hline Bias & Authors' judgement & Support for judgement \\
\hline $\begin{array}{l}\text { Random sequence genera- } \\
\text { tion (selection bias) }\end{array}$ & Unclear risk & $\begin{array}{l}\text { Although block randomisation was mentioned, the method of sequence gen- } \\
\text { eration was not (i.e. computer generated; random numbers list; toss of coin } \\
\text { etc) }\end{array}$ \\
\hline $\begin{array}{l}\text { Allocation concealment } \\
\text { (selection bias) }\end{array}$ & Unclear risk & The method of allocation concealment was not reported \\
\hline $\begin{array}{l}\text { Blinding of participants } \\
\text { and personnel (perfor- } \\
\text { mance bias) } \\
\text { All outcomes }\end{array}$ & High risk & $\begin{array}{l}\text { The nature of the intervention would make blinding of participants and per- } \\
\text { sonnel impossible }\end{array}$ \\
\hline $\begin{array}{l}\text { Blinding of outcome as- } \\
\text { sessment (detection bias) } \\
\text { All outcomes }\end{array}$ & Unclear risk & Not stated \\
\hline $\begin{array}{l}\text { Incomplete outcome data } \\
\text { (attrition bias) } \\
\text { All outcomes }\end{array}$ & Low risk & Reported the incidence of PUs for all those enrolled in the study \\
\hline $\begin{array}{l}\text { Selective reporting (re- } \\
\text { porting bias) }\end{array}$ & Low risk & Results were reported for all participants recruited \\
\hline Other bias & Unclear risk & $\begin{array}{l}\text { As the data have been extracted from an abstract it is unclear if there are any } \\
\text { other sources of bias }\end{array}$ \\
\hline
\end{tabular}

Diaz-Valenzuela 2014

$\begin{array}{ll}\text { Methods } & \text { Trial design: RCT } \\ & \text { Trial grouping: parallel } \\ & \text { Ethics and informed consent: yes } \\ & \text { Follow-up period: } 30 \text { days } \\ & \text { Sample size estimate: yes (560 people required) }\end{array}$


ITT analysis: no; number randomised: 247; number analysed: 229

Funding: Ministry of Health of the Government of Andalusia, in the call for Research Biomedical and Health Sciences in Andalusia 2010 with No. of record PI- 0772-2010

Country: Spain
Setting: nursing homes in the province of Córdoba
Number: 247 people recruited (121 olive oil group; 112 included in analys
analysis)
Inclusion criteria: people living in nursing homes with moderate or high risk
Braden scale)
Exclusion criteria: people with an existing PU; those with vascular diseas
poor medical condition
Pretreatment:
- mean age: olive oil: 84,06 years; fatty acid: 81.7 years
- mean Braden score: olive oil: 12.06 ; fatty acid: 12.09
- men: olive oil: $19 \%$; fatty acid: $27.8 \%$
- incontinent urine: olive oil: $6.6 \%$; fatty acid: $11.9 \%$
- incontinent mixed: olive oil: $83.4 \%$; fatty acid: $88.1 \%$
- repositioning: olive oil: $33,1 \%$ fatty acid: $27.8 \%$
- pressure redistribution mattresses: olive oil: $43.0 \%$; fatty acid: $32.5 \%$
- local pressure redistribution devices: olive oil: $38.8 \%$; fatty acid: $39.7 \%$
- nutritional supplements: olive oil: $8.3 \%$; fatty acid: $3.28 \%$
Both groups were equivalent at baseline

Interventions

Intervention group: application every $12 \mathrm{~h}$ to risk areas, of extra virgin olive oil (Oleicopiel)

Control group: application every $12 \mathrm{~h}$ to risk areas, of HOFAs (Mepentol)

Primary outcomes:
PU incidence
- Outcome type: dichotomous outcome
- Reporting: fully reported
- Unit of measure: numbers
- Direction: lower is better
Secondary outcomes:
Time to onset of the PU
- Outcome type: continuous outcome
- Reporting: fully reported
- Unit of measure: survival analysis
- Direction: higher is better
- Data value: endpoint

Identification

Author's name: Antonio Díaz Valenzuela

Institution: Hospital de Alta Resolución de Puente Genil

Email: adiaz@ephag.es 
Diaz-Valenzuela 2014 (Continued)

Address: Miguel Quintero Merino, 14500 Puente Genil (Córdoba)

\section{Notes}

\section{Risk of bias}

\begin{tabular}{|c|c|c|}
\hline Bias & Authors' judgement & Support for judgement \\
\hline $\begin{array}{l}\text { Random sequence genera- } \\
\text { tion (selection bias) }\end{array}$ & Low risk & $\begin{array}{l}\text { Computer software (Epidat 3.1) was used to generate random number se- } \\
\text { quence (ratio } 1: 1 \text { ) }\end{array}$ \\
\hline $\begin{array}{l}\text { Allocation concealment } \\
\text { (selection bias) }\end{array}$ & Unclear risk & Not mentioned \\
\hline $\begin{array}{l}\text { Blinding of participants } \\
\text { and personnel (perfor- } \\
\text { mance bias) } \\
\text { All outcomes }\end{array}$ & Low risk & Double-blind \\
\hline $\begin{array}{l}\text { Blinding of outcome as- } \\
\text { sessment (detection bias) } \\
\text { All outcomes }\end{array}$ & Low risk & Double-blind \\
\hline $\begin{array}{l}\text { Incomplete outcome data } \\
\text { (attrition bias) } \\
\text { All outcomes }\end{array}$ & Low risk & $\begin{array}{l}\text { Similar numbers and with similar reasons from each group were lost to fol- } \\
\text { low-up }\end{array}$ \\
\hline $\begin{array}{l}\text { Selective reporting (re- } \\
\text { porting bias) }\end{array}$ & Low risk & $\begin{array}{l}\text { Although the protocol was not viewed, PU development and time to PU devel- } \\
\text { opment were assessed. These are expected outcomes in this type of study. }\end{array}$ \\
\hline Other bias & Low risk & $\begin{array}{l}\text { Baseline characteristics were similar and there were no other risks of bias ob- } \\
\text { vious }\end{array}$ \\
\hline
\end{tabular}

Dutra 2015

Trial design: RCT
Trial grouping: parallel
Ethics and informed consent: yes
Follow-up period: 30 days or until the participant was discharged, transferred or died

\section{Sample size estimate: no}

ITT analysis: yes;number randomised: 160;number analysed: 160

Funding: trial authors state: no conflict of interest and no external funding

Country: Brazil
Setting: study was conducted in the ICU, CCU and Medical Clinic
Number: 160 participants ( 80 in each group)
Inclusion criteria: adults of both sexes, without PUs, hospitalised in the adult ICU, CCU or medical
clinic of the institution, at moderate and high risk of PUs, according to the Braden assessed $48 \mathrm{~h}$ after
admission


Dutra 2015 (Continued)

Exclusion criteria: people with PUs, and those hospitalised for $<48 \mathrm{~h}$, who died or were diagnosed as brain dead, and those who dropped out, declined or whose family members declined to participate in the study

\section{Pretreatment:}

- the mean age was 65.15 and 64.13 years in the PF and HD groups

- in both groups, most participants were men (PF $n=44,55 \%$; $H D n=47,58.8 \%)$

- white (PF $n=65,81.2 \%$; HD $n=73,91.2 \%)$

- smokers (PF $n=64,80 \%$; HD $n=56,70 \%$ )

- ethnicity differed between groups with more white people in the HD group and more people of mixed race in the PF group

- more participants in the HD group had psycho motor agitation, were unconscious and fasting

- participants in the HD group had lower risk scores on the Braden scale (indicating higher risk of PU development) when compared with participants in the PF group

Interventions

Intervention group: transparent PF was applied bilaterally to the trochanteric and sacral regions and were changed only if there was loss of adhesiveness, shear, excessive moisture, friction, presence of wrinkles, or the combination of these factors

Control group: HD was applied bilaterally to the trochanteric and sacral regions and were changed only if there was loss of adhesiveness, shear, excessive moisture, friction, presence of wrinkles, or the combination of these factors.

Primary outcomes:
PU incidence
- Outcome type: dichotomous outcome
- Reporting: fully reported
- Unit of measure: numbers
- Direction: lower is better
- Data value: endpoint

\section{Secondary outcomes:}

Performance of dressings

- Outcome type: continuous outcome

- Reporting: fully reported

- Unit of measure: mean frequency of dressing changes

- Direction: lower is better

- Data value: endpoint

Author's name: G.M. Salomé

Institution: Holy House of Mercy of Passos

Email: salomereiki@yahoo.com

Address: University of Vale do Sapucaí (UNIVÁS), Pouso Alegre, MG, Brazil

\section{Risk of bias}

Bias Authors' judgement Support for judgement


Dutra 2015 (Continued)

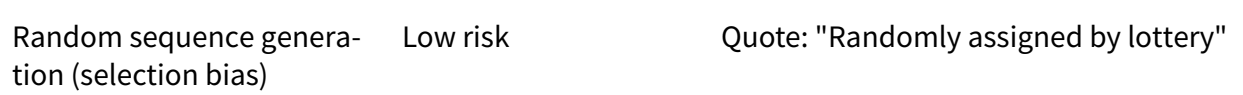
tion (selection bias)

\begin{tabular}{ll}
\hline $\begin{array}{l}\text { Allocation concealment } \\
\text { (selection bias) }\end{array}$ & Unclear risk
\end{tabular}

\begin{tabular}{ll}
\hline $\begin{array}{l}\text { Blinding of participants } \\
\begin{array}{l}\text { and personnel (perfor- } \\
\text { mance bias) }\end{array}\end{array}$ & $\begin{array}{l}\text { The nature of the intervention would make blinding of participants and per- } \\
\text { sonnel impossible }\end{array}$ \\
All outcomes & \\
\hline
\end{tabular}

\begin{tabular}{lll}
\hline $\begin{array}{l}\text { Blinding of outcome as- } \\
\text { sessment (detection bias) } \\
\text { All outcomes }\end{array}$ & Unclear risk & Not stated \\
\hline $\begin{array}{l}\text { Incomplete outcome data } \\
\begin{array}{l}\text { (attrition bias) } \\
\text { All outcomes }\end{array}\end{array}$ & Low risk & Outcomes reported for all those enrolled \\
\hline $\begin{array}{l}\text { Selective reporting (re- } \\
\text { porting bias) }\end{array}$ & Low risk & Although the protocol was not viewed, PU development was assessed \\
\hline Other bias & Low risk & None noted \\
\hline
\end{tabular}

\title{
Forni 2018
}

Methods

\author{
Trial design: RCT \\ Trial grouping: parallel \\ Ethics and informed consent: unclear \\ Follow-up period: 8 days
}

Sample size estimate: yes (359 people required)

ITT analysis: yes; number randomised: 359; number analysed: 359

Funding: sponsored by the Istituto Ortopedico Rizzoli; ClinicalTrials.gov identifier: NCT02692482

Inclusion criteria:
Participants
- people aged $\geq 65$ years with hip fragility fracture without NPUAP scale stage $\geq 2$ PU
Exclusion criteria:
- people with known allergy to the product being tested or dermatological diseases that prevent the
use of topical products
- people with peri-prosthetic or pathological fractures
Pretreatment:
- age: mean $($ SD): $84.3(7.7)$ multi-layered dressing incorporating hydrocellular foam, hyper-absorber,
lock-away core with a silicone wound contact layer; 83.2 (7.7) standard care
- female: $n(\%): 144(81,4 \%)$ multi-layered dressing incorporating hydrocellular foam, hyper-absorber,
lock-away core with a silicone wound contact layer; 145 (79.7\%) standard care


Forni 2018 (Continued)

Interventions
Intervention group: application of a multi-layered dressing incorporating hydrocellular foam, hyper-absorber lock-away core with a silicone wound contact layer over the sacral region within $24 \mathrm{~h}$ of admission and replaced when detached, wet or dirty in addition to standard care (PU risk assessment using the Braden scale within $24 \mathrm{~h}$ of admission. Place patient on pressure mattress (static or alternating pressure) if Braden score $<18$, daily inspection of the skin in the various pressure points and moving the patient every $4 \mathrm{~h}$ after surgery. Management of possible incontinence, humidity control and prevention of skin damage and rubbing/friction during postural changes as per hospital procedure)

Control group: standard care: PU risk assessment using the Braden scale within $24 \mathrm{~h}$ of admission. Place patient on pressure mattress (static or alternating pressure) if Braden score $<18$, daily inspection of the skin in the various pressure points and moving the patient every $4 \mathrm{~h}$ after surgery. Management of possible incontinence, humidity control and prevention of skin damage and rubbing/friction during postural changes as per hospital procedure

Outcomes

Primary outcome:

PU incidence in the sacral anatomical location

- Outcome type: dichotomous outcome

- Reporting: fully reported

- Unit of measure: numbers

- Direction: lower is better

- Data value: endpoint

Secondary outcomes:

PU incidence in other anatomical location

- Outcome type: dichotomous outcome

- Reporting: not reported

- Unit of measure: numbers

- Direction: lower is better

- Data value: endpoint

PU severity

- Outcome type: dichotomous outcome

- Reporting: fully reported

- Unit of measure: numbers

- Direction: lower is better

- Data value: endpoint

Adverse events: skin irritation/damage

- Outcome type: dichotomous outcome

- Reporting: not reported

- Unit of measure: numbers

- Direction: lower is better

- Data value: endpoint

Country: Italy

Setting: elderly population admitted for fragility hip fractures

Comments: no comments

Author's name: Cristiana Forni 
Forni 2018 (Continued)

Institution: Istituto Ortopedico Rizzoli

Email: cristiana.forni@ior.it

Address: Bologna, Italy, 40136

Notes Sponsor: Insituto Ortopedico Rizzoli

\section{Risk of bias}

\begin{tabular}{|c|c|c|}
\hline Bias & Authors' judgement & Support for judgement \\
\hline $\begin{array}{l}\text { Random sequence genera- } \\
\text { tion (selection bias) }\end{array}$ & Low risk & Quote: "Randomization list in blocks of ten was generated by computer" \\
\hline $\begin{array}{l}\text { Allocation concealment } \\
\text { (selection bias) }\end{array}$ & Low risk & $\begin{array}{l}\text { Quote: "Opaque envelopes were used to contain the type of treatment (new } \\
\text { polyurethane foam multilayer dressing or standard care) according to the se- } \\
\text { quence indicated by the list; the envelopes were numbered and tied in blocks } \\
\text { of ten". }\end{array}$ \\
\hline $\begin{array}{l}\text { Blinding of participants } \\
\text { and personnel (perfor- } \\
\text { mance bias) } \\
\text { All outcomes }\end{array}$ & High risk & Open-label \\
\hline $\begin{array}{l}\text { Blinding of outcome as- } \\
\text { sessment (detection bias) } \\
\text { All outcomes }\end{array}$ & High risk & Open-label \\
\hline $\begin{array}{l}\text { Incomplete outcome data } \\
\text { (attrition bias) } \\
\text { All outcomes }\end{array}$ & Low risk & All those randomised included in the final analysis \\
\hline $\begin{array}{l}\text { Selective reporting (re- } \\
\text { porting bias) }\end{array}$ & Low risk & All outcomes reported \\
\hline Other bias & Unclear risk & Baseline comparability not reported \\
\hline
\end{tabular}

Green 1974

Methods

\section{Trial design: RCT}

Trial grouping: parallel

Ethics and informed consent: unclear

Follow-up period: 3 weeks

\section{Sample size estimate: no}

ITT analysis: no; number randomised: 319; number analysed: 167

Funding: sponsored by Dermalex Co

\begin{tabular}{ll}
\hline Participants & Inclusion criteria: \\
& - geriatric patients \\
& Exclusion criteria:
\end{tabular}


Green 1974 (Continued)

- those with existing PUs

- those not at risk of PU development

- those with severe and terminal illness

\section{Pretreatment}

- 40 men, 127 women with a mean age of 81.5 years

- baseline characteristics were represented within the 2 groups within acceptable sampling limits (i.e. $5 \%$ sampling limits)

Interventions

\section{Intervention group:}

- active lotion containing: hexachlorophane $0.5 \%$, saturated hydrocarbons (squalene (cosbiol $3 \%$ ) and glyoxyle diureide), allantoin $0.2 \%$, antioxidants, lanolin, fatty acids, fatty acid esters, fatty alcohols, preservatives and distilled water

- the lotion was applied with fingers to pressure areas (sacral, trochanteric, heel and shoulder and other areas as indicated). Excess friction avoided. Skin inspected every $2 \mathrm{~h}$, participant turned and changed if soiled, washed with soap and water, skin dried and lotion applied after each cleansing. In the absence of incontinence, routine washing and reapplication of lotion was carried out every $6 \mathrm{~h}$. Bed cradles used for all participants to keep the weight of the bedding off the feet and lower legs. Participants with a score of $\leq 10$ (clinical at-risk score) were nursed on a large cell alternating pressure mattress

\section{Control:}

- inert lotion containing: lanolin, fatty acids, fatty acid esters, fatty alcohols, preservatives, distilled water and mineral oils

- the lotion was applied with fingers to pressure areas (sacral, trochanteric, heel and shoulder and other areas as indicated). Excess friction avoided

- skin inspected every $2 \mathrm{~h}$, participant turned and changed if soiled, washed with soap and water, skin dried and lotion applied after each cleansing. In the absence of incontinence, routine washing and reapplication of lotion was carried out every $6 \mathrm{~h}$

- bed cradles used for all participants to keep the weight of the bedding off the feet and lower legs

- participants with a score of $\leq 10$ (clinical at-risk score) were nursed on a large cell alternating pressure mattress

PU incidence
- Outcomes $\quad$ O Reporting: fully reported
- Unit of measure: numbers
- Direction: lower is better
- Data value: endpoint

Identification

Sponsorship source: Dermalex Co

Country: UK

Setting: geriatric participants from 6 geriatric units in the UK

Comments: no comments

Author's name: MF Green

Institution: Royal Free Hospital

Email: none provided

Address: Pond Street, London, NW3 2QG 
Green 1974 (Continued)

Risk of bias

\begin{tabular}{|c|c|c|}
\hline Bias & Authors' judgement & Support for judgement \\
\hline $\begin{array}{l}\text { Random sequence genera- } \\
\text { tion (selection bias) }\end{array}$ & Unclear risk & Not stated \\
\hline $\begin{array}{l}\text { Allocation concealment } \\
\text { (selection bias) }\end{array}$ & Unclear risk & Not stated \\
\hline $\begin{array}{l}\text { Blinding of participants } \\
\text { and personnel (perfor- } \\
\text { mance bias) } \\
\text { All outcomes }\end{array}$ & Low risk & $\begin{array}{l}\text { Quote: "The active and inert lotions were similar in appearance and texture. } \\
\text { They were randomly dispensed in identical plastic squeeze bottles to avoid } \\
\text { possible bias of application, or other nursing procedures" }\end{array}$ \\
\hline $\begin{array}{l}\text { Blinding of outcome as- } \\
\text { sessment (detection bias) } \\
\text { All outcomes }\end{array}$ & Low risk & $\begin{array}{l}\text { Quote: "The active and inert lotions were similar in appearance and texture. } \\
\text { They were randomly dispensed in identical plastic squeeze bottles to avoid } \\
\text { possible bias of application, or other nursing procedures, and of the research } \\
\text { nurses observations" }\end{array}$ \\
\hline $\begin{array}{l}\text { Incomplete outcome data } \\
\text { (attrition bias) } \\
\text { All outcomes }\end{array}$ & High risk & ITT not conducted, 152 participants excluded \\
\hline $\begin{array}{l}\text { Selective reporting (re- } \\
\text { porting bias) }\end{array}$ & Low risk & $\begin{array}{l}\text { PUs described as erythema or superficial in the results, PUs of }>\text { stage } 2 \text { were } \\
\text { grounds for discontinuation of trial }\end{array}$ \\
\hline Other bias & Low risk & None detetcted \\
\hline
\end{tabular}

Han 2011

Methods

Trial design: $\mathrm{RCT}$

Trial grouping: parallel

Ethics and informed consent: unclear

Follow-up period: 3 days

Sample size estimate: no

ITT analysis: yes; number randomised: 100; number analysed: 100

Funding: sponsored by manufacturers of the interventional product

\section{Inclusion criteria:}

- people admitted for posterior spinal surgery

\section{Exclusion criteria:}

- people with previous skin disease,

- those undergoing emergency surgery

- those with operation time of $<3 \mathrm{~h}$

\section{Pretreatment:}

- not stated 
Han 2011 (Continued)

Interventions Intervention group: Kang' huier transparent strip and foam dressing

Control group: routine operating room protective measures

\begin{tabular}{ll}
\hline Outcomes & PU incidence \\
- Outcome type: dichotomous outcome \\
- Reporting: fully reported \\
- Unit of measure: numbers \\
- Data value: endpoint \\
\hline
\end{tabular}

Identification

Sponsorship source: Shandong Province Higher Education Reform Project

Country: China

Setting: spinal surgery

Comments: no comments

Author's name: MF Green

Institution: a third-grade class-A hospital of Qingdao city

Email: none provided

Address: Nursing College of Medical College of Qingdao University, Shandong 266021 China

Notes Authors state that the 2 PUs in the intervention group occurred outside the treated area

\section{Risk of bias}

\begin{tabular}{lll}
\hline Bias & Authors' judgement & Support for judgement \\
\hline $\begin{array}{l}\text { Random sequence genera- } \\
\text { tion (selection bias) }\end{array}$ & Unclear risk & $\begin{array}{l}\text { Not described, states only that participants were randomly grouped. But au- } \\
\text { thors did not explain how the sequence was generated }\end{array}$ \\
\hline $\begin{array}{l}\text { Allocation concealment } \\
\text { (selection bias) }\end{array}$ & Unclear risk & Not described \\
\hline $\begin{array}{l}\text { Blinding of participants } \\
\text { and personnel (perfor- } \\
\text { mance bias) } \\
\text { All outcomes }\end{array}$ & High risk & Blinding impossible due to the nature of the intervention \\
\hline
\end{tabular}

\begin{tabular}{|c|c|c|}
\hline $\begin{array}{l}\text { Blinding of outcome as- } \\
\text { sessment (detection bias) } \\
\text { All outcomes }\end{array}$ & High risk & Blinding impossible due to the nature of the intervention \\
\hline $\begin{array}{l}\text { Incomplete outcome data } \\
\text { (attrition bias) } \\
\text { All outcomes }\end{array}$ & Low risk & 100 participants enrolled and all accounted for in the results \\
\hline $\begin{array}{l}\text { Selective reporting (re- } \\
\text { porting bias) }\end{array}$ & Low risk & The only outcome pre-specified was "pressure sore" \\
\hline Other bias & Unclear risk & $\begin{array}{l}\text { We had only the most important data interpreted. It is possible that there may } \\
\text { have been biases about which we are unaware. }\end{array}$ \\
\hline
\end{tabular}


Ethics and informed consent: yes

Follow-up period: 4 weeks

Sample size estimate: no

ITT analysis: yes; number randomised: 79; number analysed: 79

Funding: not stated

\section{Participants}

\section{Inclusion criteria:}

- written informed consent was obtained from each participant. If the mental capability of the participant to decide on participation was uncertain, the legal representative of the participant was asked for consent

- participants had to be able to participate for an evaluation for 4 weeks

- participants had to rest on an anti-PU mattress

- participants had to be at high risk of developing PU according to the Braden scale using a cut-off point of 20

\section{Exclusion criteria:}

- patients who were treated with another, unrelated ointment or cream

- people who were to undergo or had undergone surgery $<2$ weeks prior

- people with existing PU

- people with dark skin because of difficulty in assessment

\section{Pretreatment}

- men: $27.7 \%$ control; $25 \%$ placebo; $37.9 \%$ DMSO

- not incontinent: $16.7 \%$ control; $6.3 \%$ placebo; $0 \%$ DMSO

- age (median): 81.5 years control; 85 years placebo; 80.5 years DMSO

- no significant differences in participant characteristics

Placebo: 3-min massage of the buttock, heel, and ankle regions with an "indifferent" cream (Vaseline-cetomacrogol) combined with a $30^{\circ}$ position change. This procedure was repeated every $6 \mathrm{~h}$ for 4 weeks

Control: $30^{\circ}$ position change, repeated every $6 \mathrm{~h}$ for 4 weeks

\begin{tabular}{ll} 
Outcomes & PU incidence \\
- Outcome type: dichotomous outcome \\
- Reporting: fully reported \\
- Unit of measure: numbers \\
- Direction: lower is better \\
\hline
\end{tabular}

Identification

Sponsorship source: not stated

Country: the Netherlands 
Houwing 2008 (Continued)

Setting: 8 nursing homes

Comments: no comments

Author's name: R Houwing

Institution: Department Dermatology, Deventer Ziekenhuis

Email: houwingr@dz.nl

Address: Department Dermatology, Deventer Ziekenhuis, The Netherlands

\section{Notes}

\section{Risk of bias}

\begin{tabular}{|c|c|c|}
\hline Bias & Authors' judgement & Support for judgement \\
\hline $\begin{array}{l}\text { Random sequence genera- } \\
\text { tion (selection bias) }\end{array}$ & Low risk & Throw of a dice (additional information from the study author) \\
\hline $\begin{array}{l}\text { Allocation concealment } \\
\text { (selection bias) }\end{array}$ & Unclear risk & Not stated \\
\hline $\begin{array}{l}\text { Blinding of participants } \\
\text { and personnel (perfor- } \\
\text { mance bias) } \\
\text { All outcomes }\end{array}$ & Low risk & Stated as double-blind \\
\hline $\begin{array}{l}\text { Blinding of outcome as- } \\
\text { sessment (detection bias) } \\
\text { All outcomes }\end{array}$ & Low risk & $\begin{array}{l}\text { Blinded, quote: "presence of a pressure ulcer confirmed by two external ob- } \\
\text { servers" }\end{array}$ \\
\hline $\begin{array}{l}\text { Incomplete outcome data } \\
\text { (attrition bias) } \\
\text { All outcomes }\end{array}$ & Low risk & None excluded \\
\hline $\begin{array}{l}\text { Selective reporting (re- } \\
\text { porting bias) }\end{array}$ & Low risk & $\begin{array}{l}\text { Outcome measure was the presence of a PU, this was reported by the study } \\
\text { authors }\end{array}$ \\
\hline Other bias & Unclear risk & There is no indication that the cluster design was accounted for in the analysis \\
\hline
\end{tabular}

Kalowes 2016

Methods

Trial design: RCT

Trial grouping: parallel

Ethics and informed consent: ethics approval obtained, exemption from consent obtained.

Follow-up period: participants were followed by the research team until discharged from the ICU (range 4-14 days). Information about subsequent PU development was retrieved from the electronic medical record.

Sample size estimate: yes, estimated as requiring 185/group

ITT analysis: yes; number randomised: 366; number analysed: 366 
Kalowes 2016 (Continued)

Funding: not declared in the published paper, but a report of a conference presentation declared support for the study by Molnlycke; manufacturer of the intervention product

\section{Participants}

\section{Inclusion criteria:}

- all critically ill people admitted to an ICU in a large Level 2 Magnet hospital

- $\geq 18$ years

- Braden score $\leq 13$

- intact skin

\section{Exclusion criteria:}

- Braden score $\geq 14$

- existing PU

- moisture-related skin damage

- receiving end-of-life care

\section{Pretreatment}

- age, mean (SD): intervention: 64.6 (17.7) years; control: 67.3 (16.2) years

- women, $\mathrm{n}(\%)$ : intervention: 81 (44.0); control: 82 (45.1)

- Braden score, mean (SD): intervention: 11.8 (1.3); control: 11.9 (1.4)

- $\geq 4$ comorbid conditions, $\mathrm{n}(\%)$ : intervention: 66 (35.9); control: 67 (36.8)

- APACHE III score, mean (SD): intervention: 58.6 (29.3); control: 49.5 (23.6)

- baseline characteristics did not differ significantly between the groups

Interventions

Intervention group: silicone dressing (Meplex border sacrum) was applied within $24 \mathrm{~h}$ of admission. Dressing changed every 3 days or when soiled or dislodged. Usual care was also provided.

Control group: usual care (no dressing). Usual care consisted of Braden scoring on admission and every shift; full skin assessment every shift; use of a special bed; routine positioning; heel off-loading; incontinence skin care

\section{Outcomes}

\section{Primary outcome:}

PU incidence

- Outcome type: dichotomous outcome

- Reporting: fully reported

- Unit of measure: numbers

- Direction: lower is better

- Data value: endpoint

\section{Secondary outcomes:}

Stage of PUs

- Outcome type: dichotomous outcome

- Reporting: fully reported

- Unit of measure: numbers

- Direction: lower is better

- Data value: endpoint

Location of PUs

- Outcome type: dichotomous outcome

- Reporting: fully reported

- Unit of measure: numbers

- Direction: none 
Kalowes 2016 (Continued)

- Data value: endpoint

Sponsorship source: Molnlycke
Country: USA
Setting: medical/surgical/trauma ICU and a cardiac ICU
Comments: no comments
Author's name: Peggy Kalowes
Institution: Memorial Care Health System
Email: p.kalowes@memorialcare.org
Address: Longbeach Memorial, 2801 Atlantic Avenue, Long Beach CA, 90806, USA
Unclear if the intervention was continued following discharge from the ICU, although PU incidence was
collected. Also unclear but unlikely that nurses diagnosing PUs in the post-ICU wards underwent in-
ter-rater reliability testing.

\section{Risk of bias}

\begin{tabular}{lll}
\hline Bias & Authors' judgement & Support for judgement \\
\hline $\begin{array}{l}\text { Random sequence genera- } \\
\text { tion (selection bias) }\end{array}$ & Low risk & Randomisation, quote: "using a computerized research randomiser" \\
\hline $\begin{array}{l}\text { Allocation concealment } \\
\text { (selection bias) }\end{array}$ & Unclear risk & $\begin{array}{l}\text { Quote: "Randomization of participants was undertaken by the principal inves- } \\
\text { tigator or study nurse" }\end{array}$ \\
& Comment: unclear if allocation was concealed \\
\hline
\end{tabular}

\begin{tabular}{|c|c|c|}
\hline $\begin{array}{l}\text { Blinding of participants } \\
\text { and personnel (perfor- }\end{array}$ & High risk & $\begin{array}{l}\text { Not stated, but difference in the appearance of dressing makes blinding im- } \\
\text { possible }\end{array}$ \\
\hline
\end{tabular}

mance bias)

All outcomes

\begin{tabular}{ll}
\hline Blinding of outcome as- & High risk $\quad$ Quote: "Dressing pulled back daily for routine skin assessment" \\
sessment (detection bias) &
\end{tabular}

All outcomes

Incomplete outcome data Low risk All participants accounted for
(attrition bias)
All outcomes

Selective reporting (re- Low risk $\quad$ All expected outcomes reported
porting bias)

Other bias Unclear risk Information about the study only available as conference abstract

Lupianez-Perez 2015

$\begin{array}{ll}\text { Methods } & \text { Trial design: } \mathrm{RCT} \\ \text { Trial grouping: parallel } \\ \text { Ethics and informed consent: yes }\end{array}$


Lupianez-Perez 2015 (Continued)

Follow-up period: 16 weeks

Sample size estimate: yes, a sample size of 765 participants was required

ITT analysis: yes; number randomised: 831; number analysed: 831

Funding: this research was undertaken pursuant to the independent clinical calls and proposals managed by the Spanish Ministry of Health, Social Policy and Equality (EC11-526).

\section{Participants}

\section{Inclusion criteria:}

- people receiving the home nursing service who were aged $>18$ years

- aided by a family member or paid caregiver for treatment application

- risk of impaired skin integrity according to the Braden Scale 16, identified by a nurse

- and nutritional status of 10 according to the Mini Nutritional Assessment (MNA)

\section{Exclusion criteria:}

people were excluded:

- if they refused to take part in the trial

- if their permanent address was outside the catchment area of the corresponding health centre

- if they planned to be elsewhere during the follow-up period

- if they required hospitalisation during the sampling period

- if they were terminally ill

- or if they already had PU

\section{Pretreatment}

- mean age of the participants was 80.56 years (SD 13.36)

- mean level of PU risk, measured on the Braden scale, was 12.91 (SD 2.33)

- risk of malnutrition, assessed by MNA, was 6.98 (SD 2.08)

- over half of the participants, in both groups $(299 ; 68.4 \%$ and $284 ; 72.1 \%$ in the control and target groups, respectively), suffered some degree of some cognitive impairment

- no differences in baseline characteristics between the groups

Interventions

Olive oil: dressing was applied bilaterally to the trochanteric and sacral regions and changed only if there was loss of adhesiveness, shear, excessive moisture, friction, presence of wrinkles, or the combination of these factors

HOFA: dressing was applied bilaterally to the trochanteric and sacral regions and changed only if there was loss of adhesiveness, shear, excessive moisture, friction, presence of wrinkles, or the combination of these factors

Outcomes $\quad$ PU incidence
- Outcome type: dichotomous outcome
- Unit of measure: numbers
- Direction: lower is better
- Data value: endpoint

Identification

Sponsorship source: this research was undertaken pursuant to the Independent Clinical Calls and Proposals managed by the Spanish Ministry of Health, SocialPolicy and Equality (EC11-526). The funders had no role in study design, data collection and analysis, decision to publish, or preparation of the manuscript

Country: Spain 
Lupianez-Perez 2015 (Continued)

Setting: people included in the immobilised patients programme receiving the home nursing service provided by health centres

Comments: no comments

Author's name: Inmaculada Lupianez-Perez

Institution: Malaga-Guadalhorce Primary Healthcare District, Andalusian Health Service, Malaga, Spain

Email: ilupianezperez@gmail.com

Address: Andalusian Health ServiceC/La Unión, 29651 Mijas Costa, Malaga

\begin{tabular}{|c|c|c|}
\hline Notes & Pre-treatment: there & Iere no differences between the groups \\
\hline \multicolumn{3}{|l|}{ Risk of bias } \\
\hline Bias & Authors' judgement & Support for judgement \\
\hline $\begin{array}{l}\text { Random sequence genera- } \\
\text { tion (selection bias) }\end{array}$ & Low risk & $\begin{array}{l}\text { Participants were randomly allocated to a } 1: 1 \text { control/target group scheme by } \\
\text { a computer system }\end{array}$ \\
\hline $\begin{array}{l}\text { Allocation concealment } \\
\text { (selection bias) }\end{array}$ & Low risk & $\begin{array}{l}\text { When patient met the inclusion criteria his/her nurse was informed of the } \\
\text { group to which they had been allocated by a telephone call from a centralised } \\
\text { randomisation unit. }\end{array}$ \\
\hline $\begin{array}{l}\text { Blinding of participants } \\
\text { and personnel (perfor- } \\
\text { mance bias) } \\
\text { All outcomes }\end{array}$ & Low risk & Triple-blind. Both topical applications were delivered using a spray \\
\hline $\begin{array}{l}\text { Blinding of outcome as- } \\
\text { sessment (detection bias) } \\
\text { All outcomes }\end{array}$ & Low risk & Triple-blind \\
\hline $\begin{array}{l}\text { Incomplete outcome data } \\
\text { (attrition bias) } \\
\text { All outcomes }\end{array}$ & Low risk & $\begin{array}{l}\text { Both per protocol and ITT analysis were reported. However, the ITT analysis } \\
\text { included imputed data. }\end{array}$ \\
\hline $\begin{array}{l}\text { Selective reporting (re- } \\
\text { porting bias) }\end{array}$ & Unclear risk & $\begin{array}{l}\text { The protocol stated that the primary outcome was stage } 2 \text { PUs and the sec- } \\
\text { ondary outcome cost. Only PU data were reported. Additionally, data were re- } \\
\text { ported by area affected rather than by total number of PUs }\end{array}$ \\
\hline Other bias & Unclear risk & $\begin{array}{l}\text { Unequal number of participants allocated to each group (may indicate selec- } \\
\text { tion bias) } 28 \% \text { loss to follow-up in olive oil group compared with } 34 \% \text { in the } \\
\text { HOFA group }\end{array}$ \\
\hline
\end{tabular}

Nakagami 2007

Methods

Trial design: RCT

Trial grouping: within-participant (participant acting as their own control)

Ethics and informed consent: yes

Follow-up period: 3 weeks

Sample size estimate: yes, the estimated sample size was 33, and therefore 37 participants were enrolled, assuming a loss to follow-up of $10 \%$ 
Nakagami 2007 (Continued)

ITT analysis: yes; number randomised: 37; number analysed: 37

Funding: this study was supported by a Grant-in-Aid for scientific research from the Ministry of Education, Culture, Sports, Science and Technology, Japan [(B) (2) 16390637]

\section{Participants}

\section{Inclusion criteria:}

- aged $\geq 65$

- Braden score of $<15$

\section{Exclusion criteria:}

- impaired judgement

- lack of consciousness

- presence of a PU or skin disorder in the study area

- poor general medical condition

- inability to position the body in either a right or left lateral position

\section{Pretreatment}

- age, years, mean (SD): $86.4 \pm 8.2$

- women: 28 (75.7\%)

- Braden score, mean (SD): $10.4 \pm 1.2$

- bedridden: 37 (100\%)

- body weight: $11 \mathrm{~kg}$, mean (SD): $36.6 \pm 2.8$

- no support surfaces: $11(29.7 \%)$

- diagnosis: cerebrovascular disease: 30 (81.1\%); heart disease: 10 (27.0\%); diabetes mellitus: 4 (10.8\%)

\section{Interventions Intervention group:}

- PPD (dressing with skin adhesive layer (hydrocolloid), a support layer (urethane film) and an outer layer of multi filament nylon fibres

- applied to either the right or the left trochanter

- PPD replaced every week

\section{Control group:}

- participants acted as their own control, i.e. no dressing was applied to the opposite trochanter

Outcomes $\quad$ PU incidence
- Outcome type: dichotomous outcome
- Unit of measure: numbers
- Direction: lower is better
- Data value: endpoint
Incidence of persistent erythema
- Outcome type: dichotomous outcome
- Reporting: fully reported
- Unit of measure: numbers
- Direction: lower is better
- Data value: endpoint


Nakagami 2007 (Continued)

Setting: 500-bed geriatric hospital

Comments: no comments

Author's name: G Najagami

Institution: Division of Health Sciences and Nursing, Graduate School of Medicine

Email: not provided

Address: University of Tokyo, Tokyo, Japan

Notes PU classification system not clearly described

\section{Risk of bias}

\begin{tabular}{|c|c|c|}
\hline Bias & Authors' judgement & Support for judgement \\
\hline $\begin{array}{l}\text { Random sequence genera- } \\
\text { tion (selection bias) }\end{array}$ & Unclear risk & Not stated \\
\hline $\begin{array}{l}\text { Allocation concealment } \\
\text { (selection bias) }\end{array}$ & Unclear risk & Not stated \\
\hline $\begin{array}{l}\text { Blinding of participants } \\
\text { and personnel (perfor- } \\
\text { mance bias) } \\
\text { All outcomes }\end{array}$ & High risk & Not blinded, quote: "impossible due to the type of intervention" \\
\hline $\begin{array}{l}\text { Blinding of outcome as- } \\
\text { sessment (detection bias) } \\
\text { All outcomes }\end{array}$ & High risk & $\begin{array}{l}\text { Not blinded, quote: "test area outlined so that the dressing applied back to the } \\
\text { same area" }\end{array}$ \\
\hline $\begin{array}{l}\text { Incomplete outcome data } \\
\text { (attrition bias) } \\
\text { All outcomes }\end{array}$ & Low risk & ITT conducted \\
\hline $\begin{array}{l}\text { Selective reporting (re- } \\
\text { porting bias) }\end{array}$ & Low risk & All outcomes reported in the paper were those outlined by the study authors \\
\hline Other bias & High risk & Investigators were part of the group that developed the PPD \\
\hline
\end{tabular}

Otero 2017

\begin{tabular}{ll}
\hline Methods & Trial design: $\mathrm{RCT}$ \\
& Trial grouping: parallel groups \\
& Ethics and informed consent: yes \\
& Follow-up period: followed participants for 5 - $10 \mathrm{~h}$ following treatment (average treatment $14.5 \mathrm{~h}$ ) \\
& Sample size estimate: a total of 152 participants needed to be recruited. \\
& ITT analysis: no; number randomised: 171 ; number analysed: 152 \\
& Funding: not stated \\
\hline Participants & Adults with acute respiratory failure, requiring non invasive ventilation
\end{tabular}


Otero 2017 (Continued)

\section{Inclusion criteria:}

- adults ( $\geq 18$ years)

- absence of facial soft tissue injury

- absence of facial anatomy structural deformity

\section{Exclusion criteria:}

- people not agreeing to participate and not signing the informed consent form

- people with facial soft tissue lesions

- people with any deformity of the facial anatomy

\section{Pretreatment}

- $56.6 \%$ men; $43.4 \%$ women

- The average Norton score of the total population was $10.69(\mathrm{SD}=2.85)$

Interventions

\section{Intervention groups:}

- adhesive thin dressing (ATD): the oro-nasal mask was applied over skin protected with adhesive thin polyurethane foam dressings

- adhesive foam dressing: the oro-nasal mask was applied over skin protected with adhesive foam dressings

- HOFA: the oro-nasal mask was applied over skin protected with a solution of HOFA, gently applied without rubbing on the chin, cheekbones, nasal bridge and forehead

\section{Control:}

The oro-nasal mask was applied directly over the participant's skin

\begin{tabular}{l} 
PU incidence \\
- Outcomes \\
- Reporting: fully reported for those analysed \\
- Unit of measure: numbers \\
- Direction: lower is better \\
Adverse events \\
- Outcome type: dichotomous outcome \\
- Reporting: fully reported for those analysed \\
- Unit of measure: numbers \\
- Direction: lower is better \\
\hline
\end{tabular}

Identification

Sponsorship source: Istituto Ortopedico Rizzoli

Country: Spain

Setting: HDU section of an emergency and critical care department in the University General Hospital in Madrid, Spain

Comments: no comments

\section{Author's name: DP Otero}

Institution: University General Hospital Gregorio Marañón; Gregorio Marañón Healthcare Research Institute-Nursing Department (IiSGM); Centre for Health Sciences San Rafael-Antonio Nebrija University,

Email: david.penha.otero@hotmail.com 
Otero 2017 (Continued)

Address: Madrid, Spain

\section{Notes}

\section{Risk of bias}

\begin{tabular}{|c|c|c|}
\hline Bias & Authors' judgement & Support for judgement \\
\hline $\begin{array}{l}\text { Random sequence genera- } \\
\text { tion (selection bias) }\end{array}$ & Low risk & $\begin{array}{l}\text { Quote: "we randomised subjects into four different groups, using specifically } \\
\text { designed tables of random numbers" }\end{array}$ \\
\hline $\begin{array}{l}\text { Allocation concealment } \\
\text { (selection bias) }\end{array}$ & Unclear risk & Not stated \\
\hline $\begin{array}{l}\text { Blinding of participants } \\
\text { and personnel (perfor- } \\
\text { mance bias) } \\
\text { All outcomes }\end{array}$ & High risk & $\begin{array}{l}\text { Quote: "As the researchers were also part of the care team at the HDU, it was } \\
\text { impossible to implement a blinded study" }\end{array}$ \\
\hline $\begin{array}{l}\text { Blinding of outcome as- } \\
\text { sessment (detection bias) } \\
\text { All outcomes }\end{array}$ & Low risk & Quote: "We employed independent double evaluations" \\
\hline $\begin{array}{l}\text { Incomplete outcome data } \\
\text { (attrition bias) } \\
\text { All outcomes }\end{array}$ & High risk & $\begin{array}{l}\text { Quote: "A total of } 19 \text { patients were lost to follow-up; } 4 \text { died before the end of } \\
\text { the trial, and data recording was incomplete for } 4 \text { patients" }\end{array}$ \\
\hline $\begin{array}{l}\text { Selective reporting (re- } \\
\text { porting bias) }\end{array}$ & Low risk & All outcomes reported \\
\hline Other bias & Low risk & None noted \\
\hline
\end{tabular}

Qiuli 2010

Methods

Trial design: RCT

Trial grouping: parallel groups

Ethics and informed consent: not stated

Follow-up period: 7 days

Sample size estimate: not stated

ITT analysis: yes; number randomised: 64; number analysed: 64

Funding: not stated

\section{Participants}

\section{Inclusion criteria:}

- Waterlow score18-23

- Department of neurosurgery

\section{Exclusion criteria:}

- not reported

\section{Pretreatment}


Qiuli 2010 (Continued)

- 30 men and 34 women

- aged 55-80 years

- 26 suffered from hemiplegia, 4 with paraplegia, 24 with coma and 6 with advanced tumours

- Waterlow Pressure Sore Risk Assessment Scale scores:18 to 23,

- haemoglobin: $90 \mathrm{~g} / \mathrm{L}$ to $110 \mathrm{~g} / \mathrm{L}$

- fasting blood glucose: $4.2-6.5 \mathrm{mmol} / \mathrm{L}$

- 16 participants suffered from incontinence

Interventions

Intervention group: Mepilex dressing applied to weight-bearing bony areas

Control group: massage of bony areas

Both groups turned 2-3 hourly and nursed on air cushion beds

\begin{tabular}{ll}
\hline Outcomes & PU incidence \\
- Outcome type: dichotomous outcome \\
- Reporting: fully reported \\
- Unit of measure: numbers \\
- Direction: lower is better \\
\hline
\end{tabular}

Identification

Sponsorship source: not stated

Country: China

Setting: long-term care

Comments: no comments

Author's name: Bao Qiuli

Institution: Department of Neurosurgery

Email: not provided

Address: Second Affiliated Hospital of Harbin Medical University

\begin{tabular}{|c|c|c|}
\hline Notes & \multicolumn{2}{|c|}{ PU classification system not described } \\
\hline \multicolumn{3}{|l|}{ Risk of bias } \\
\hline Bias & Authors' judgement & Support for judgement \\
\hline $\begin{array}{l}\text { Random sequence genera- } \\
\text { tion (selection bias) }\end{array}$ & Unclear risk & Not stated \\
\hline $\begin{array}{l}\text { Allocation concealment } \\
\text { (selection bias) }\end{array}$ & Unclear risk & Not stated \\
\hline $\begin{array}{l}\text { Blinding of participants } \\
\text { and personnel (perfor- } \\
\text { mance bias) } \\
\text { All outcomes }\end{array}$ & High risk & $\begin{array}{l}\text { Not stated, but difference in the appearance of dressing makes blinding im- } \\
\text { possible }\end{array}$ \\
\hline $\begin{array}{l}\text { Blinding of outcome as- } \\
\text { sessment (detection bias) } \\
\text { All outcomes }\end{array}$ & High risk & Not stated \\
\hline
\end{tabular}


Qiuli 2010 (Continued)

Incomplete outcome data Low risk All participants included in the final analysis
(attrition bias)

All outcomes

All outcomes reported in the paper were those outlined by the authors

Selective reporting (re- Low risk All outcomes reported in the paper were those outlined by the authors
porting bias)

\begin{tabular}{ll}
\hline Other bias $\quad$ Unclear risk & Baseline characteristics not reported \\
\hline
\end{tabular}

Saab 2015

$\begin{array}{ll}\text { Methods } & \text { Trial design: RCT } \\ \text { Trial grouping: parallel groups } & \text { Ethics and informed consent: not stated } \\ & \text { Follow-up period: not stated } \\ & \text { Sample size estimate: not stated } \\ \text { ITT analysis: yes; number randomised: 80; number a } & \text { Funding: not stated } \\ \text { Inclusion criteria: } \\ \text { - people admitted to SICU from July-November 2014 } \\ \text { Exclusion criteria: } \\ \text { - not reported } \\ \text { Pretreatment: } \\ \text { - } 44 \% \text { women } \\ \text { - mean age was 62 (17.2) years } \\ \text { - mean Braden score was 15.1 }\end{array}$

Intervention group:
Interventions
- application of a multi-layered dressing incorporating hydrocellular foam, hyper-absorber, lock-away
- the buttocks and the sacrum were examined daily
- the dressing was replaced as needed
Control group:
- no dressing

\begin{tabular}{ll}
\hline Outcomes & $P U$ incidence \\
- Outcome type: dichotomous outcome \\
- Unit of measure: numbers \\
- Direction: lower is better \\
Data value: endpoint
\end{tabular}

Identification

Sponsorship source: not reported 
Saab 2015 (Continued)

\author{
Country: USA \\ Setting: surgical ICU \\ Comments: no comment
}

Author's name: I Saab

Institution: Henry Ford Hospital

Email: not provided

Address: 2799 West Grand Boulevard, Detroit, MA 48202

\title{
Notes
}

\section{Risk of bias}

\begin{tabular}{|c|c|c|}
\hline Bias & Authors' judgement & Support for judgement \\
\hline $\begin{array}{l}\text { Random sequence genera- } \\
\text { tion (selection bias) }\end{array}$ & Unclear risk & Sequence generation not stated \\
\hline $\begin{array}{l}\text { Allocation concealment } \\
\text { (selection bias) }\end{array}$ & Unclear risk & Not stated \\
\hline $\begin{array}{l}\text { Blinding of participants } \\
\text { and personnel (perfor- } \\
\text { mance bias) } \\
\text { All outcomes }\end{array}$ & High risk & Open-label \\
\hline $\begin{array}{l}\text { Blinding of outcome as- } \\
\text { sessment (detection bias) } \\
\text { All outcomes }\end{array}$ & High risk & Open-label \\
\hline $\begin{array}{l}\text { Incomplete outcome data } \\
\text { (attrition bias) } \\
\text { All outcomes }\end{array}$ & Low risk & Outcomes reported for those randomised to each group \\
\hline $\begin{array}{l}\text { Selective reporting (re- } \\
\text { porting bias) }\end{array}$ & Low risk & PU incidence reported \\
\hline Other bias & Unclear risk & As this is an abstract, this element is unclear \\
\hline
\end{tabular}

Santamaria 2015

Trial design: RCT
Trial grouping: parallel groups
Ethics and informed consent: yes
Follow-up period: not stated
Sample size estimate: yes, required a total of 220 people per group
ITT analysis: yes; number randomised: $440 ;$ number analysed: 440
Funding: funded by Molnlycke Health Care, the manufacturer of the intervention product


Santamaria 2015 (Continued)

Participants

Inclusion criteria:

- ED and ICU admission for critical illness and/or major trauma

- > 18 years of age

Exclusion criteria:

- suspected or actual spinal injury precluding the patient being turned

- pre-existing sacral or heel PU

- trauma to sacrum and/or heels

\section{Pretreatment}

- age, mean years (SD years): intervention: 54 (20.8); control: 56 (20.5)

- gender, M/F: intervention: 126/89; control: 132/82

- Braden, mean (SD): intervention: 12 (4.2); control: 12 (3.9)

- Apache 11, mean: intervention: 19; control: 19.5

Interventions

Intervention characteristics:

- soft silicone multi-layered foam dressing

- the dressing was applied bilaterally to the trochanteric and sacral regions

- the dressings were changed only if there was loss of adhesiveness, shear, excessive moisture, friction, presence of wrinkles, or the combination of these factors

\section{Control:}

- no dressing applied

PU incidence
- Outcome type: dichotomous outcome
- Reporting: fully reported
- Unit of measure: numbers
- Direction: lower is better
- Data value: endpoint
Cost benefit
- Outcome type: continuous outcome
- Reporting: partially reported
- Unit of measure: Australian dollars
- Direction: lower is better
- Data value: endpoint

Setting: ICU

Comments: no comments

Author's name: N Santamaria N

Institution: Royal Melbourne Hospital

Email: nick.santamaria@mh.org.au 
Santamaria 2015 (Continued)

Address: Level 6 Office for Research, Royal Melbourne Hospital, Grattan Street, Parkville VIC 3050, Aus-

tralia

Notes

\section{Risk of bias}

\begin{tabular}{lll}
\hline Bias & Authors' judgement & Support for judgement \\
\hline $\begin{array}{l}\text { Random sequence genera- } \\
\text { tion (selection bias) }\end{array}$ & Low risk & $\begin{array}{l}\text { Participants were randomised in the ED to either the intervention group or to } \\
\text { the control group by retrieving the next envelope in a pre-prepared series of } \\
\text { envelopes that had been randomised using a computer-generated set of ran- } \\
\text { dom numbers to determine group allocation }\end{array}$
\end{tabular}

\begin{tabular}{lll}
\hline $\begin{array}{l}\text { Allocation concealment } \\
\text { (selection bias) }\end{array}$ & Unclear risk & Whether the envelopes were opaque and sealed was not reported \\
\hline $\begin{array}{l}\text { Blinding of participants } \\
\text { and personnel (perfor- } \\
\text { mance bias) }\end{array}$ & High risk & Cannot blind as one group has a dressing and the other doesn't \\
All outcomes &
\end{tabular}

\begin{tabular}{|c|c|c|}
\hline $\begin{array}{l}\text { Blinding of outcome as- } \\
\text { sessment (detection bias) } \\
\text { All outcomes }\end{array}$ & High risk & The outcome assessor was not independent of the study team \\
\hline $\begin{array}{l}\text { Incomplete outcome data } \\
\text { (attrition bias) } \\
\text { All outcomes }\end{array}$ & Low risk & $\begin{array}{l}\text { The analysis was based on ITT ( } 33 \text { ) where all participants randomised to the in- } \\
\text { tervention were analysed regardless of protocol violations }\end{array}$ \\
\hline $\begin{array}{l}\text { Selective reporting (re- } \\
\text { porting bias) }\end{array}$ & Low risk & PU incidence, PU location, time to PU development and cost were reported \\
\hline Other bias & Unclear risk & $\begin{array}{l}\text { The sample size calculation was based on a control event rate of } 4.0 \% \text { (pre- } \\
\text { sumably this was known from existing hospital data). In the study, the control } \\
\text { event rate was } 13.1 \% \text {, raising questions about the accuracy of PU diagnosis in } \\
\text { the control group during the study. The study was registered on clinicaltrial- } \\
\text { s.gov but only after data collection had begun. }\end{array}$ \\
\hline
\end{tabular}

Smith 1985

Trial design: RCT
Trial grouping: parallel groups
Ethics and informed consent: yes
Follow-up period: 24 weeks
Sample size estimate: not stated
ITT analysis: yes; number randomised: 258 ; number analysed: 258
Funding: grant from WB Pharmaceuticas

Participants Inclusion criteria:

- people with intact skin 
Smith 1985 (Continued)

\section{Exclusion criteria:}

- not stated

\section{Pretreatment}

- age, mean: intervention: 82 years; control: 83 years

- gender, F/M: intervention: 104/25; control: $106 / 23$

- incontinent urine: intervention: $19 \%$; control: $29 \%$

- incontinent faeces: intervention: $29 \%$; control: $42 \%$

Interventions

Intervention group: Conotrane (silicone cream; $20 \%$ dimethicone 350; and a broad spectrum antiseptic (0.05\% hydrargaphen)), skin washed, dried and ointment applied

Control group: Unguentum cream, skin washed, dried and ointment applied

\begin{tabular}{ll}
\hline Outcomes & PU incidence \\
- Outcome type: dichotomous outcome \\
- Reporting: fully reported \\
- Unit of measure: numbers \\
- Datrection: lower is better \\
\hline
\end{tabular}

Identification

Sponsorship source: WB Pharmaceuticals

Country: UK

Setting: long stay

Comments: no comment

Author's name: RG Smith

Institution: Department of Geriatric Medicine

Email: not stated

Address: City Hospital, Greenbank Drive, Edingburgh, UK

Notes

Risk of bias

\begin{tabular}{|c|c|c|}
\hline Bias & Authors' judgement & Support for judgement \\
\hline $\begin{array}{l}\text { Random sequence genera- } \\
\text { tion (selection bias) }\end{array}$ & Unclear risk & Not stated \\
\hline $\begin{array}{l}\text { Allocation concealment } \\
\text { (selection bias) }\end{array}$ & Unclear risk & Not stated \\
\hline $\begin{array}{l}\text { Blinding of participants } \\
\text { and personnel (perfor- } \\
\text { mance bias) } \\
\text { All outcomes }\end{array}$ & Low risk & $\begin{array}{l}\text { Quote: "The placebo ointment had been suitably scented so that it was indis- } \\
\text { tinguishable from the active preparation" }\end{array}$ \\
\hline $\begin{array}{l}\text { Blinding of outcome as- } \\
\text { sessment (detection bias) } \\
\text { All outcomes }\end{array}$ & Low risk & $\begin{array}{l}\text { No mention within the article; quote: "The placebo ointment had been suit- } \\
\text { ably scented so that it was indistinguishable from the active preparation" }\end{array}$ \\
\hline
\end{tabular}

Dressings and topical agents for preventing pressure ulcers (Review) 
Smith 1985 (Continued)
Incomplete outcome data Low risk
Results table 1: of 258 participants
(attrition bias)
Data presented related to those who entered the study
All outcomes

All outcomes reported in the paper were those outlined by the trial authors

Selective reporting (re- Low risk porting bias)

\begin{tabular}{ll}
\hline Other bias $\quad$ Unclear risk & $\begin{array}{l}\text { One third more participants in the placebo group were incontinent of urine } \\
\text { and one quarter more were incontinent of faeces when compared with the } \\
\text { treatment group. }\end{array}$
\end{tabular}

Torra i Bou 2005

Trial design: RCT
Trial grouping: parallel groups
Ethics and informed consent: yes
Follow-up period: 30 days
Sample size estimate: yes, 188 people per group required
ITT analysis: no; number randomised: $380 ;$ number analysed: 359
Funding: Laboratorios Bama-Geve SA, Barcelona, Spain
Inclusion criteria:
- participants had to be at medium, high or very high risk of developing PUs
- participants had to be able to participate for an evaluation period of 30 days
- participants or their carers needed to provide written consent to take part

\section{Exclusion criteria:}

- were terminally ill or receiving chemotherapy

- had > 3 PUs

- were allergic to HOFA or topical fatty products

- had peripheral vascular disease

Pretreatment

- age, mean (SD): intervention: 84.8 (6.7); control: 84.8 (5.9)

- gender: F/M: intervention: 48/17; control: 46/19

\section{Interventions Intervention group:}

- Mepentol, a HOFA compound (consisting of: oleic acid, palmitic acid, stearic acid, palmitoleic acid, linoleic acid, gamma-linoleic acid, arachidonic acid, and eicosenoic acid),

- applied twice daily to $\geq 3$ areas of the body, sacrum, trochanter, heels

\section{Control group:}

- a compound consisting of trisostearin (99.4\%) and perfume $(0.6 \%)$

- applied twice daily to $\geq 3$ areas of the body, sacrum, trochanter, heels

Outcomes PU incidence

- Outcome type: dichotomous outcome 
Torra i Bou 2005 (Continued)

- Reporting: fully reported

- Unit of measure: numbers

- Direction: lower is better

- Data value: endpoint

Cost benefit

- Outcome type: continuous outcome

- Reporting: partially reported

- Unit of measure: Euro

- Direction: lower is better

- Data value: endpoint

Identification

Sponsorship source: Laboratorios Bama-Geve SA, Barcelona, Spain.

Country: Spain

Setting: internal medicine or surgical patients at high risk of pressure injury

Comments: no comment

Author's name: J E Torra i Bou

Institution: Clinical and Education Manager, Advanced Wound Care Division, Smith \& Nephew, Spain;

Email: jetorrabou@hotmail.com

Address: not stated

Notes

\section{Risk of bias}

\begin{tabular}{|c|c|c|}
\hline Bias & Authors' judgement & Support for judgement \\
\hline $\begin{array}{l}\text { Random sequence genera- } \\
\text { tion (selection bias) }\end{array}$ & Unclear risk & Did not state how the randomisation sequence was generated \\
\hline $\begin{array}{l}\text { Allocation concealment } \\
\text { (selection bias) }\end{array}$ & Unclear risk & $\begin{array}{l}\text { Coded randomisation in closed envelope, did not state that the envelopes } \\
\text { were opaque }\end{array}$ \\
\hline $\begin{array}{l}\text { Blinding of participants } \\
\text { and personnel (perfor- } \\
\text { mance bias) } \\
\text { All outcomes }\end{array}$ & Low risk & $\begin{array}{l}\text { Blinded, quote: "only the coordinator had access to the packaging codes so } \\
\text { neither the investigator nor patient knew which group a patient had been allo- } \\
\text { cated to" }\end{array}$ \\
\hline $\begin{array}{l}\text { Blinding of outcome as- } \\
\text { sessment (detection bias) } \\
\text { All outcomes }\end{array}$ & Low risk & $\begin{array}{l}\text { Blinded, "only the coordinator had access to the packaging codes so neither } \\
\text { the investigator nor patient knew which group a patient had been allocated } \\
\text { to" }\end{array}$ \\
\hline $\begin{array}{l}\text { Incomplete outcome data } \\
\text { (attrition bias) } \\
\text { All outcomes }\end{array}$ & High risk & $\begin{array}{l}\text { ITT not conducted, results presented for } 167 \text { and } 164 \text { participants and not for } \\
\text { the original } 380 \text { enrolled }\end{array}$ \\
\hline $\begin{array}{l}\text { Selective reporting (re- } \\
\text { porting bias) }\end{array}$ & Low risk & All outcomes reported in the paper were those outlined by the trial authors \\
\hline Other bias & Low risk & None detected \\
\hline
\end{tabular}


Trial grouping: parallel groups

Ethics and informed consent: not stated

Follow-up period: 3 weeks

Sample size estimate: not stated

ITT analysis: no; number randomised: 120; number analysed: 104

Funding: not stated

\section{Participants}

\section{Inclusion criteria:}

- Norton score between 5-14, indicating risk of PUs

- chair-bound individuals

\section{Exclusion criteria:}

- had existing PUs

- severe or terminal disease

- likely period of stay in the ward of $<3$ weeks

\section{Pretreatment}

- age, mean (range): intervention: 82.2 (53-98); control: 82.9 (64-97)

- gender: F/M: intervention: $40 / 14$; control: $37 / 13$ nicotinate, zinc stearate, isopropyl myristate, dimethicone 350, cetrimide and glycol) applied at least twice daily, and after changing, if wet or soiled

Control group: participants' buttocks and sacral areas washed and dried, and Dermalex (hexachlorophane, squalene and allantoin) applied at least twice daily, and after changing, if wet or soiled

Outcomes $\quad$ PU incidence
- Outcome type: dichotomous outcome
- Reporting: fully reported
- Dnit of measure: numbers
- Data value: endpoint

Identification

Sponsorship source: none stated

Country: UK

Setting: geriatric medicine

Comments: no comment

Author's name: TJM Van Der Cammen

Institution: Lewisham and Hither green Hospitals

Email: none provided

Address: Lewisham and Hither Green Hospitals, London, UK 
Van Der Cammen 1987 (Continued)

Notes Data presented for 104 participants

\section{Risk of bias}

\begin{tabular}{|c|c|c|}
\hline Bias & Authors' judgement & Support for judgement \\
\hline $\begin{array}{l}\text { Random sequence genera- } \\
\text { tion (selection bias) }\end{array}$ & Unclear risk & Not stated \\
\hline $\begin{array}{l}\text { Allocation concealment } \\
\text { (selection bias) }\end{array}$ & Unclear risk & Not stated \\
\hline $\begin{array}{l}\text { Blinding of participants } \\
\text { and personnel (perfor- } \\
\text { mance bias) } \\
\text { All outcomes }\end{array}$ & Low risk & Quote "... this formulation was compared, in a double blind clinical trial..." \\
\hline $\begin{array}{l}\text { Blinding of outcome as- } \\
\text { sessment (detection bias) } \\
\text { All outcomes }\end{array}$ & Unclear risk & $\begin{array}{l}\text { Not mentioned and although unclear, it is probable that outcome assessment } \\
\text { was blinded, given that the trial was "double-blinded" }\end{array}$ \\
\hline $\begin{array}{l}\text { Incomplete outcome data } \\
\text { (attrition bias) } \\
\text { All outcomes }\end{array}$ & High risk & $\begin{array}{l}\text { ITT not conducted, data presented relate to the number who concluded the } \\
\text { study excluding those withdrawn }\end{array}$ \\
\hline $\begin{array}{l}\text { Selective reporting (re- } \\
\text { porting bias) }\end{array}$ & Low risk & All outcomes reported in the paper are those outlined by the trial authors \\
\hline Other bias & High risk & $\begin{array}{l}\text { Corresponding author member of staff of the manufacturer of the product un- } \\
\text { der investigation }\end{array}$ \\
\hline
\end{tabular}

Walker 2015

\begin{tabular}{|c|c|}
\hline Methods & $\begin{array}{l}\text { Trial design: RCT } \\
\text { Trial grouping: parallel groups } \\
\text { Ethics and informed consent: yes } \\
\text { Follow-up period: } 5 \text { days } \\
\text { Sample size estimate: yes: a sample size of } 1500 \text { ( } 750 \text { in each group) would be } \\
\text { required to test the effectiveness of this intervention } \\
\text { ITT analysis: yes; number randomised: } 77 \text {; number Aanalysed: } 77 \\
\text { Funding: this study was funded by the National Health and Medical Research Council's Centre of Re- } \\
\text { search Excellence in Nursing, and an Early Career Researcher Mentored Grant from the Centre from } \\
\text { Health Practice Innovation, Griffith University }\end{array}$ \\
\hline Participants & $\begin{array}{l}\text { Inclusion criteria: } \\
\text { - } \geq 18 \text { years of age } \\
\text { - able to provide written informed consent either in person or via their family member or legal guardian } \\
\text { - } \text { assessed as being at high risk or greater of } \mathrm{PI} \text { (as per a risk assessment score of } 15+\text { using the Waterlow } \\
\text { Scale) on hospital admission to the medical or surgical study wards } \\
\text { - expected hospital length of stay } \geq 72 \mathrm{~h} \text { following recruitment }\end{array}$ \\
\hline
\end{tabular}


Walker 2015 (Continued)

\section{Exclusion criteria:}

- suspected or actual spinal injury that prevented the patient being repositioned

- lower back surgery (lumbar spine) that prevented the application of a sacral dressing

- existing sacral PI, injury, or allergy in the sacral area at the time of hospital admission

- faecal incontinence at the time of hospital admission

- unable to speak or understand English with no interpreter present

\section{Pretreatment:}

- age, median: intervention: 77 years; control: 72 years

- women: intervention: 59\%; control: $82 \%$

- Waterlow median: intervention 17 ; control 17

Interventions

Intervention group: silicone foam border dressing. Dressing changed every 3 days, skin assessed daily, in addition to usual care

Control group: no dressing; usual care only

PU incidence
- Outcomes
- Reporting: fully reported
- Unit of measure: numbers
- Direction: lower is better
- Data value: endpoint

Identification

Sponsorship source: this study was funded by the National Health and Medical Research Council's Centre of Research Excellence in Nursing, and an Early Career Researcher Mentored Grant from the Centre from Health Practice Innovation, Griffith University

Country: Australia

Setting: Surgical Care Unit; the ED; or participating medical and orthopaedic surgical wards

Comments: no comment

Author's name: Rachel Walker

Institution: Princess Alexandra Hospital

Email: r.walker@griffith.edu.au

Address: Nursing Practice Development Unit, Princess Alexandra Hospital, Building 15, Level 2, Ipswich Road, Woolloongabba QLD 4102

Notes

Risk of bias

\begin{tabular}{lll}
\hline Bias & Authors' judgement & Support for judgement \\
\hline $\begin{array}{l}\text { Random sequence genera- } \\
\text { tion (selection bias) }\end{array}$ & Low risk & $\begin{array}{l}\text { Random allocation of participants to either the routine-care group or the } \\
\text { dressing group was achieved using an online clinical trial co-ordinating web- } \\
\text { site }\end{array}$ \\
\hline $\begin{array}{l}\text { Allocation concealment } \\
\text { (selection bias) }\end{array}$ & Low risk & $\begin{array}{l}\text { Using an online clinical trial co-ordinating website accessed by the research } \\
\text { nurse using a smart phone or tablet }\end{array}$ \\
\hline
\end{tabular}


Walker 2015 (Continued)
Blinding of participants
High risk
Unable to blind as one group had a dressing and the other didn't and personnel (performance bias)

All outcomes

\begin{tabular}{|c|c|c|}
\hline $\begin{array}{l}\text { Blinding of outcome as- } \\
\text { sessment (detection bias) }\end{array}$ & Low risk & $\begin{array}{l}\text { Sacral assessment was undertaken by a suitably qualified blind-to-interven- } \\
\text { tion ("blinded") nurse assessor }\end{array}$ \\
\hline
\end{tabular}

Incomplete outcome data Low risk All participants were accounted for
(attrition bias)

All outcomes

\begin{tabular}{lll}
\hline $\begin{array}{l}\text { Selective reporting (re- } \\
\text { porting bias) }\end{array}$ & Low risk & $\begin{array}{l}\text { The published protocol was sighted and outcomes in the study were consis- } \\
\text { tent with those named in the protocol. }\end{array}$ \\
\hline Other bias & Low risk & $\begin{array}{l}\text { This was a small feasibility study so was not powered to find differences be- } \\
\text { tween groups. }\end{array}$
\end{tabular}

ED: emergency department; h: hour(s); HD: hydrocolloid dressing; HDU: high-dependency unit; HOFA: hyperoxygenated fatty acids; ICU: Intensive Care Unit, Coronary Care Unit (CCU); ITT: intention-to-treat analysis; NPUAP: National Pressure Ulcer Advisory Panel; PF: polyurethane film; PI: pressure injury; PPD: pressure ulcer preventative dressing; PU: pressure ulcer; $\mathbf{R C T}$ : randomised controlled trial

Characteristics of excluded studies [ordered by study ID]

\begin{tabular}{|c|c|}
\hline Study & Reason for exclusion \\
\hline Alvarez Vázquez 2014 & Wrong study design \\
\hline Callaghan 1998 & Not an RCT \\
\hline Declaire 1997 & Not an RCT \\
\hline Duimel-Peeters 2007 & Cross-over trial \\
\hline Garcia Fernandez 2005 & Review of a previous study by Torra i Bou \\
\hline Hsu 2011 & Quasi-experimental \\
\hline Huang 2009 & Not an RCT \\
\hline Kalowes 2013 & In previous version of the review \\
\hline Kuisma 1987 & Treatment intervention not prevention \\
\hline Park 2014a & Wrong study design \\
\hline Park 2014b & Duplicate \\
\hline Santamaria 2013 & Duplicate \\
\hline Smith 2010 & Not an RCT \\
\hline Stoker 1990 & Treatment intervention not prevention \\
\hline
\end{tabular}




\section{Study \\ Reason for exclusion}

Torra i Bou 2009

Cost analysis from an unpublished study, presented at a Pressure Ulcer Advisory Panel meeting in 2002. No abstract available

Wen-Yi 2013

Wrong study design

Characteristics of studies awaiting assessment [ordered by study ID]

Aloweni 2017

\begin{tabular}{ll} 
Methods & RCT \\
\hline Participants & High-risk patients from medical-surgical wards in an acute tertiary hospital \\
\hline Interventions & Three study groups: \\
& - Silicone foam dressing plus standard care \\
& - Fatty acids oil spray plus standard care \\
& Standard care only
\end{tabular}

Outcomes Incidence of sacral PI

Notes

Guo 2015

\begin{tabular}{ll}
\hline Methods & RCT \\
\hline Participants & People with lumbar burst fracture, pelvic fracture, lower limb fracture \\
\hline Interventions & It is unclear what the interventions are precisely \\
& $\begin{array}{l}\text { Quote: "The patients in the observation group using Bayer Tanzania foam dressing, paste it in pa- } \\
\text { tients with sacrococcygeal bedsore prevention, protection of the skin. In the study group, the same } \\
\text { as the observation group, the same foam dressing, the patient will be affixed to the end of the com- } \\
\text { pression area of the sacral area, to protect, other with the observation group." }\end{array}$
\end{tabular}

Outcomes Incidence of PU

Notes

Imbulana 2018

\begin{tabular}{ll}
\hline Methods & RCT \\
\hline Participants & Infants admitted to the neonatal ICU \\
\hline Interventions & Nasal barrier dressing versus standard care \\
\hline Outcomes & Quote: "any nasal injury" \\
\hline
\end{tabular}


Imbulana 2018 (Continued)

Notes

Kim 2016

\begin{tabular}{ll}
\hline Methods & RCT \\
\hline Participants & Patients admitted to a surgical ICU \\
\hline Interventions & Transparent film dressing applied on the sacrum and coccyx, versus usual care \\
\hline Outcomes & Prevalence and risk of PU
\end{tabular}

\section{Notes}

Tai 2016

\begin{tabular}{ll}
\hline Methods & RCT \\
\hline Participants & People using noninvasive positive pressure ventilators \\
\hline Interventions & Foam dressing versus HD \\
\hline Outcomes & Incidence of facial PI
\end{tabular}

\section{Notes}

Wang 2016

\begin{tabular}{ll}
\hline Methods & RCT \\
\hline Participants & People using nasal mask, or nose and mouth mask, noninvasive ventilator \\
\hline Interventions & Adhesive dressing versus usual care \\
\hline Outcomes & Incidence of PU \\
\hline Notes & \\
\hline
\end{tabular}

HD: hydrocolloid dressing; ICU: intensive care unit; PI: pressure injury; PU: pressure ulcer; RCT: randomised controlled trial

Characteristics of ongoing studies [ordered by study ID]

\section{JPRN-UMIN000024609}

\begin{tabular}{ll}
\hline Trial name or title & Prevention effect of wound dressings for pressure sores in high-risk patients \\
\hline Methods & RCT \\
\hline
\end{tabular}


JPRN-UMIN000024609 (Continued)

\begin{tabular}{ll} 
Participants & $\begin{array}{l}\text { People with high risks of pressure sores who have chronic severe diarrhoea and/or extremely weak } \\
\text { skins among the people who will be admitted in the participating medical institutions }\end{array}$ \\
\hline Interventions & $\begin{array}{l}\text { Wound dressing applied to the areas of the sacrum bone and the coccyx versus no wound dressing } \\
\text { over the areas of the sacrum bone and the coccyx }\end{array}$ \\
\hline Outcomes & Incidence of pressure sores \\
\hline Starting date 22 April 2016 \\
\hline Contact information & hsanada-tky@umin.ac.jp \\
\hline Notes & Sponsor: Japanese Society of Wound Ostomy Continence Management
\end{tabular}

\begin{tabular}{ll} 
NCT01640418 & Prevention of sacral pressure ulcers with preventive dressing \\
\hline Methods & RCT \\
\hline Participants & Age $>18$ years; admission to a high-risk unit; Braden score $\leq 19$ \\
\hline Interventions & Meplex Border Sacrum dressing vs standard care (no dressing) \\
\hline Outcomes & PU \\
\hline Starting date & 2012 \\
\hline Contact information & n.bouvy@mumc.nl \\
\hline Notes & Sponsor: Maastricht University Medical Centre \\
\hline
\end{tabular}

\begin{tabular}{ll} 
NCT02295735 & \\
\hline Trial name or title & RCT \\
\hline Methods & Major trauma patients being at high or very high risk according to the University hospital's criteria \\
\hline Participants & Meplex Border Sacrum and heel dressing vs standard care (no dressing) \\
\hline Interventions & Incidence of PU > l; number of dressings used; time to heal \\
\hline Outcomes & June 2015 \\
\hline Starting date & jan.kottner@charite.de \\
\hline Contact information & Sponsor: Jan Kottner \\
\hline Notes &
\end{tabular}


NCT02565745

\begin{tabular}{ll}
\hline Trial name or title & $\begin{array}{l}\text { Impact of the use of dressings versus lubrication of the skin with cream to prevent pressure ulcers: } \\
\text { clinical trial (PENFUP) }\end{array}$ \\
\hline Methods & RCT \\
\hline Participants & People with a high or very high risk of PU development assessed using the Braden Scale \\
\hline Interventions & HD vs conventional lubricated skin \\
\hline Outcomes & PU incidence; length of stay; total days; time to event; PU stage; time to first walk in hospital; cost \\
\hline of hospitalisation
\end{tabular}

\begin{tabular}{ll} 
NCT03039179 & $\begin{array}{l}\text { Effectiveness of polyurethane foam in preventing the onset of pressure sores in a pediatric ortho- } \\
\text { pedic population }\end{array}$ \\
\hline Methods & RCT \\
\hline Participants & Children with intact skin aged > 3 years who underwent surgery for flat foot \\
\hline Interventions & Polyurethane foam applied to the heel, versus standard care \\
\hline Outcomes & Incidence of heel PUs; pain \\
\hline Starting date & 1 July 2014 \\
\hline Contact information & cristiana.forni@ior.it \\
\hline Notes & Sponsor: Istituto Ortopedico Rizzoli \\
\hline
\end{tabular}

\section{RBR-4s8qjx}

\begin{tabular}{ll}
\hline Trial name or title & $\begin{array}{l}\text { Randomized clinical trial about multilayered soft silicone foam dressing to transparent } \\
\text { polyurethane film: Effectiveness in pressure ulcer prevention }\end{array}$
\end{tabular}

\begin{tabular}{ll}
\hline Methods & RCT \\
\hline Participants & $\begin{array}{l}\text { 18 years old; high risk and very high risk for developing PU from the Braden scale; has been evalu- } \\
\text { ated by the researcher within } 24 \text { h of hospitalization; show the heels to be healthy }\end{array}$ \\
\hline Interventions & Multilayered soft silicone foam dressing versus transparent film \\
\hline Outcomes & PU incidence; skin temperature \\
\hline Starting date & 22 July 2017 \\
\hline
\end{tabular}


RBR-4s8qjx (Continued)

Contact information

rheasilviasoares@yahoo.com.br

Notes

Sponsor: Universidade Federal de Santa Maria - UFSM - Santa Maria, RS, Brazil

PU: pressure ulcer; $\mathbf{R C T}$ : randomised controlled trial

DATA AND ANALYSES

Comparison 1. Fatty acid versus other topical intervention or standard care

\begin{tabular}{|c|c|c|c|c|}
\hline Outcome or subgroup title & No. of studies & $\begin{array}{l}\text { No. of partici- } \\
\text { pants }\end{array}$ & Statistical method & Effect size \\
\hline 1 Pressure ulcer & 5 & & Risk Ratio (M-H, Fixed, 95\% Cl) & Subtotals only \\
\hline 1.1 Fatty acid versus olive oil & 2 & 1060 & Risk Ratio (M-H, Fixed, 95\% Cl) & $1.28[0.76,2.17]$ \\
\hline $\begin{array}{l}1.2 \text { Fatty acid versus control } \\
\text { compound }\end{array}$ & 1 & 331 & Risk Ratio (M-H, Fixed, 95\% Cl) & $0.42[0.22,0.80]$ \\
\hline $\begin{array}{l}\text { 1.3 Fatty acid versus standard } \\
\text { care }\end{array}$ & 2 & 187 & Risk Ratio (M-H, Fixed, 95\% Cl) & $0.70[0.41,1.18]$ \\
\hline $\begin{array}{l}2 \text { Pressure ulcer (high-quality } \\
\text { studies) }\end{array}$ & 1 & 831 & Risk Ratio (M-H, Fixed, 95\% Cl) & $1.46[0.77,2.75]$ \\
\hline 3 Adverse event & 1 & 831 & Risk Ratio (M-H, Fixed, 95\% Cl) & $2.22[0.20,24.37]$ \\
\hline
\end{tabular}

Analysis 1.1. Comparison 1 Fatty acid versus other topical intervention or standard care, Outcome 1 Pressure ulcer.

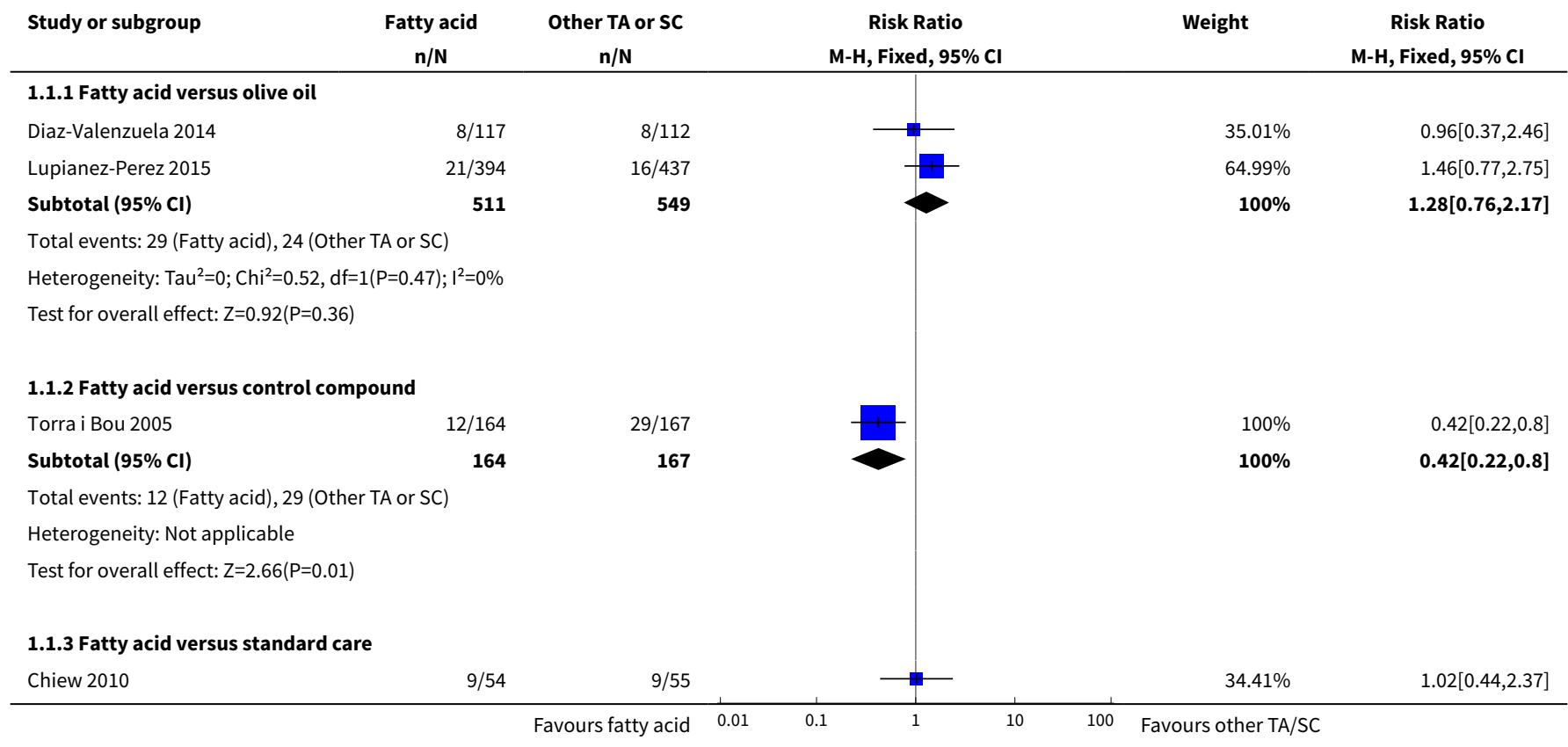




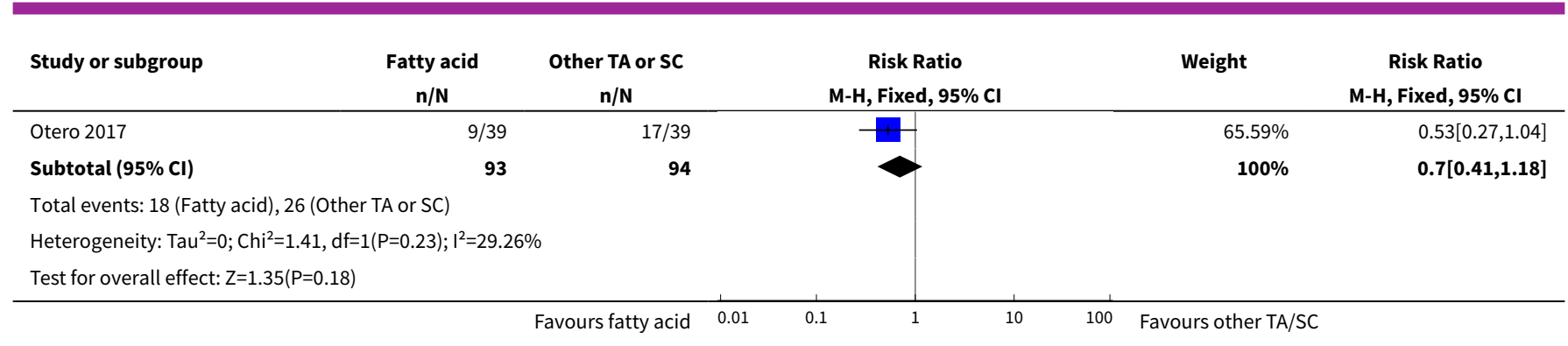

Analysis 1.2. Comparison 1 Fatty acid versus other topical intervention or standard care, Outcome 2 Pressure ulcer (high-quality studies).

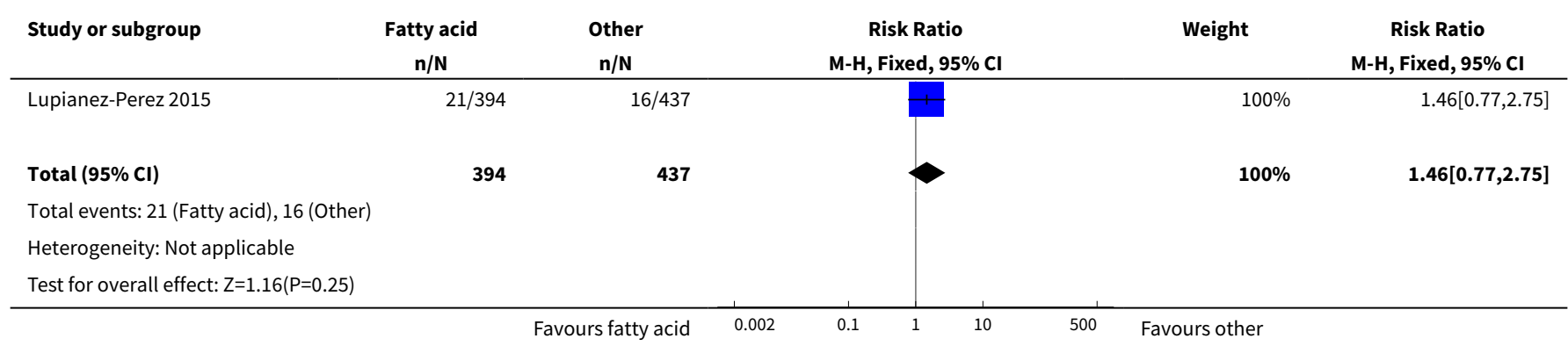

Analysis 1.3. Comparison 1 Fatty acid versus other topical intervention or standard care, Outcome 3 Adverse event.

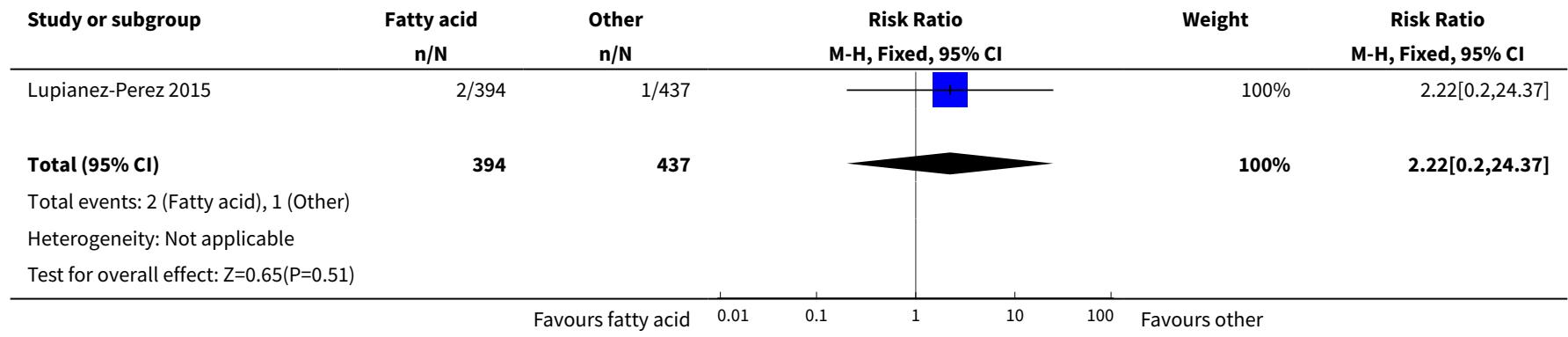

\section{Comparison 2. Active topical agent versus placebo/control}

\begin{tabular}{lllll}
\hline $\begin{array}{l}\text { Outcome or subgroup ti- } \\
\text { tle }\end{array}$ & No. of studies & $\begin{array}{l}\text { No. of partici- } \\
\text { pants }\end{array}$ & Statistical method & Effect size \\
\hline 1 Pressure ulcer & 4 & & Risk Ratio (M-H, Fixed, 95\% Cl) & Subtotals only \\
\hline $\begin{array}{l}1.1 \text { Active lotion versus } \\
\text { placebo }\end{array}$ & 1 & 167 & Risk Ratio (M-H, Fixed, 95\% Cl) & $0.73[0.45,1.19]$ \\
\hline $\begin{array}{l}1.2 \text { DSMO cream versus } \\
\text { placebo }\end{array}$ & 1 & 61 & Risk Ratio (M-H, Fixed, 95\% Cl) & $1.99[1.10,3.57]$ \\
\hline
\end{tabular}




\begin{tabular}{lllll}
\hline $\begin{array}{l}\text { Outcome or subgroup ti- } \\
\text { tle }\end{array}$ & No. of studies & $\begin{array}{l}\text { No. of partici- } \\
\text { pants }\end{array}$ & Statistical method & Effect size \\
\hline $\begin{array}{l}\text { 1.3 Conotrane versus } \\
\text { placebo }\end{array}$ & 1 & 258 & Risk Ratio (M-H, Fixed, 95\% Cl) & $0.74[0.52,1.07]$ \\
\hline $\begin{array}{l}\text { 1.4 Prevasore versus con- } \\
\text { trol }\end{array}$ & 1 & 120 & Risk Ratio (M-H, Fixed, 95\% Cl) & $0.33[0.04,3.11]$ \\
\hline 2 Pressure ulcer stage & 1 & & Risk Ratio (M-H, Fixed, 95\% Cl) & Subtotals only \\
\hline 2.1 Stage 3 & 1 & 258 & Risk Ratio (M-H, Fixed, 95\% Cl) & $1.25[0.34,4.55]$ \\
\hline 2.2 Stage 4 & 1 & 258 & Risk Ratio (M-H, Fixed, 95\% Cl) & $0.33[0.01,8.11]$ \\
\hline 3 Adverse event & 1 & 167 & Odds Ratio (M-H, Fixed, 95\% Cl) & $6.14[0.29,129.89]$ \\
\hline
\end{tabular}

Analysis 2.1. Comparison 2 Active topical agent versus placebo/control, Outcome 1 Pressure ulcer.

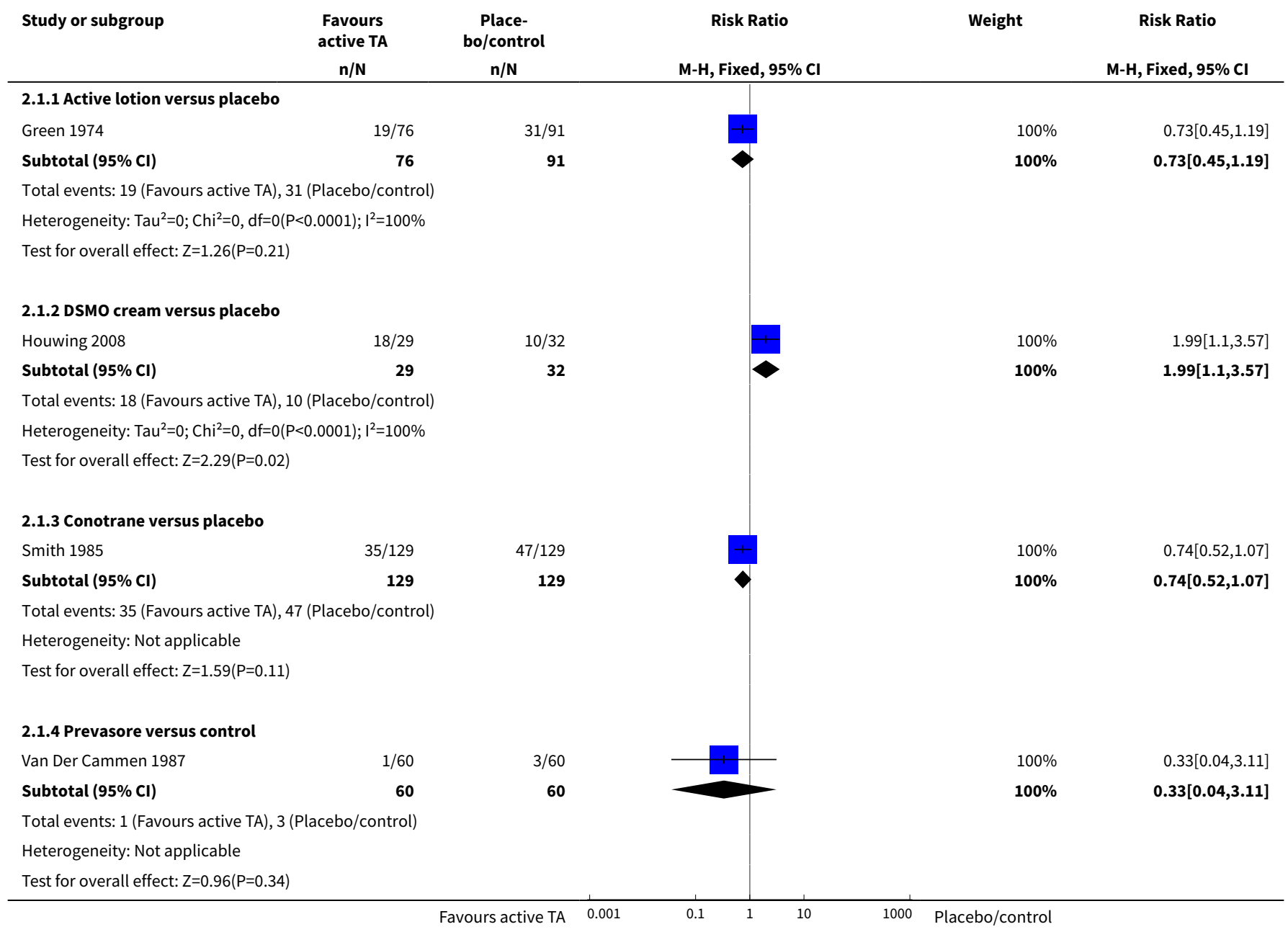


Analysis 2.2. Comparison 2 Active topical agent versus placebo/control, Outcome 2 Pressure ulcer stage.

\begin{tabular}{|c|c|c|c|c|c|}
\hline Study or subgroup & $\begin{array}{c}\text { Active top- } \\
\text { ical agent } \\
n / N \\
\end{array}$ & $\begin{array}{c}\begin{array}{c}\text { Place- } \\
\text { bo/control } \\
\text { n/N }\end{array} \\
\end{array}$ & $\begin{array}{c}\text { Risk Ratio } \\
\text { M-H, Fixed, 95\% Cl }\end{array}$ & Weight & $\begin{array}{c}\text { Risk Ratio } \\
\text { M-H, Fixed, } 95 \% \mathrm{Cl}\end{array}$ \\
\hline \multicolumn{6}{|l|}{ 2.2.1 Stage 3} \\
\hline Smith 1985 & $5 / 129$ & $4 / 129$ & & $100 \%$ & $1.25[0.34,4.55]$ \\
\hline Subtotal $(95 \% \mathrm{CI})$ & 129 & 129 & & $100 \%$ & $1.25[0.34,4.55]$ \\
\hline \multicolumn{6}{|c|}{ Total events: 5 (Active topical agent), 4 (Placebo/control) } \\
\hline \multicolumn{6}{|c|}{ Test for overall effect: $Z=0.34(P=0.73)$} \\
\hline \multicolumn{6}{|l|}{ 2.2.2 Stage 4} \\
\hline Smith 1985 & $0 / 129$ & $1 / 129$ & - & $100 \%$ & $0.33[0.01,8.11]$ \\
\hline Subtotal $(95 \% \mathrm{Cl})$ & 129 & 129 & & $100 \%$ & $0.33[0.01,8.11]$ \\
\hline \multicolumn{6}{|c|}{ Total events: 0 (Active topical agent), 1 (Placebo/control) } \\
\hline \multicolumn{6}{|c|}{ Test for overall effect: $Z=0.67(P=0.5)$} \\
\hline Test for subgroup dif & $57, d f=1(P=0.45)$, & & & & \\
\hline
\end{tabular}

Analysis 2.3. Comparison 2 Active topical agent versus placebo/control, Outcome 3 Adverse event.

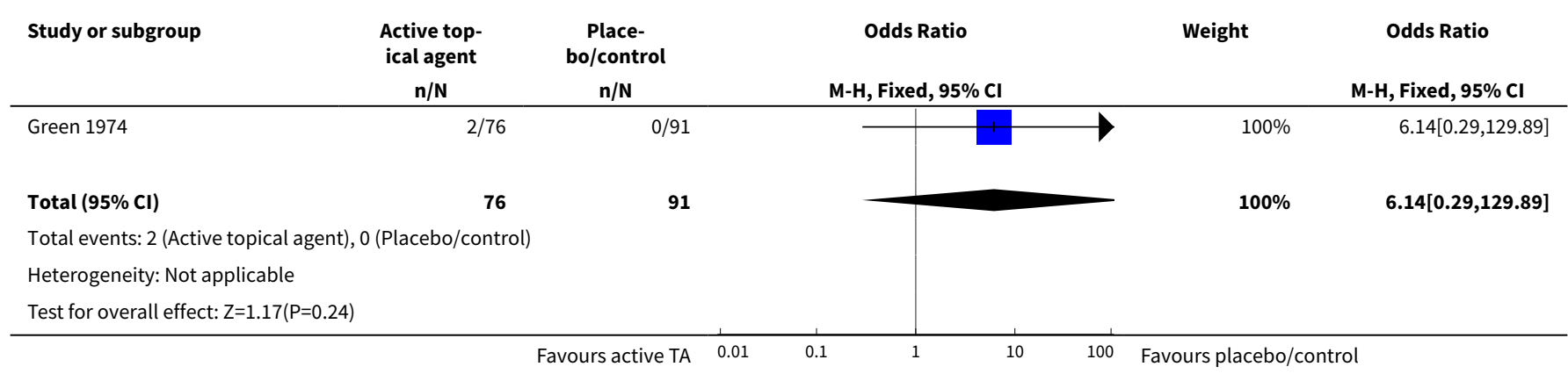

\section{Comparison 3. Silicone dressing versus no dressing}

\begin{tabular}{lllll}
\hline $\begin{array}{l}\text { Outcome or subgroup } \\
\text { title }\end{array}$ & No. of studies & $\begin{array}{l}\text { No. of partici- } \\
\text { pants }\end{array}$ & Statistical method & Effect size \\
\hline $\begin{array}{lllll}\text { 1 Any pressure ulcer } \\
\text { 2 Pressure ulcer (high- } \\
\text { quality studies) }\end{array}$ & 1 & 1247 & Risk Ratio (M-H, Fixed, 95\% Cl) & $0.25[0.16,0.41]$ \\
\hline 3 Pressure ulcer stage & 5 & 77 & Risk Ratio (M-H, Random, 95\% Cl) & $1.95[0.18,20.61]$ \\
\hline 3.1 Stage 1 & 3 & Risk Ratio (M-H, Random, 95\% Cl) & Subtotals only \\
\hline 3.2 Stage 2 & 4 & Risk Ratio (M-H, Random, 95\% Cl) & $0.27[0.08,0.90]$ \\
\hline 3.3 Stage 4 & 1 & 1090 & Risk Ratio (M-H, Random, 95\% Cl) & $0.40[0.17,0.94]$ \\
\hline
\end{tabular}




\begin{tabular}{lllll}
\hline $\begin{array}{l}\text { Outcome or subgroup } \\
\text { title }\end{array}$ & No. of studies & $\begin{array}{l}\text { No. of partici- } \\
\text { pants }\end{array}$ & Statistical method & Effect size \\
\hline 3.4 Unstageable & 1 & 366 & Risk Ratio (M-H, Random, 95\% Cl) & $0.20[0.01,4.09]$ \\
\hline 3.5 Deep tissue injury & 1 & 366 & Risk Ratio (M-H, Random, 95\% Cl) & $0.99[0.06,15.69]$ \\
\hline
\end{tabular}

Analysis 3.1. Comparison 3 Silicone dressing versus no dressing, Outcome 1 Any pressure ulcer.

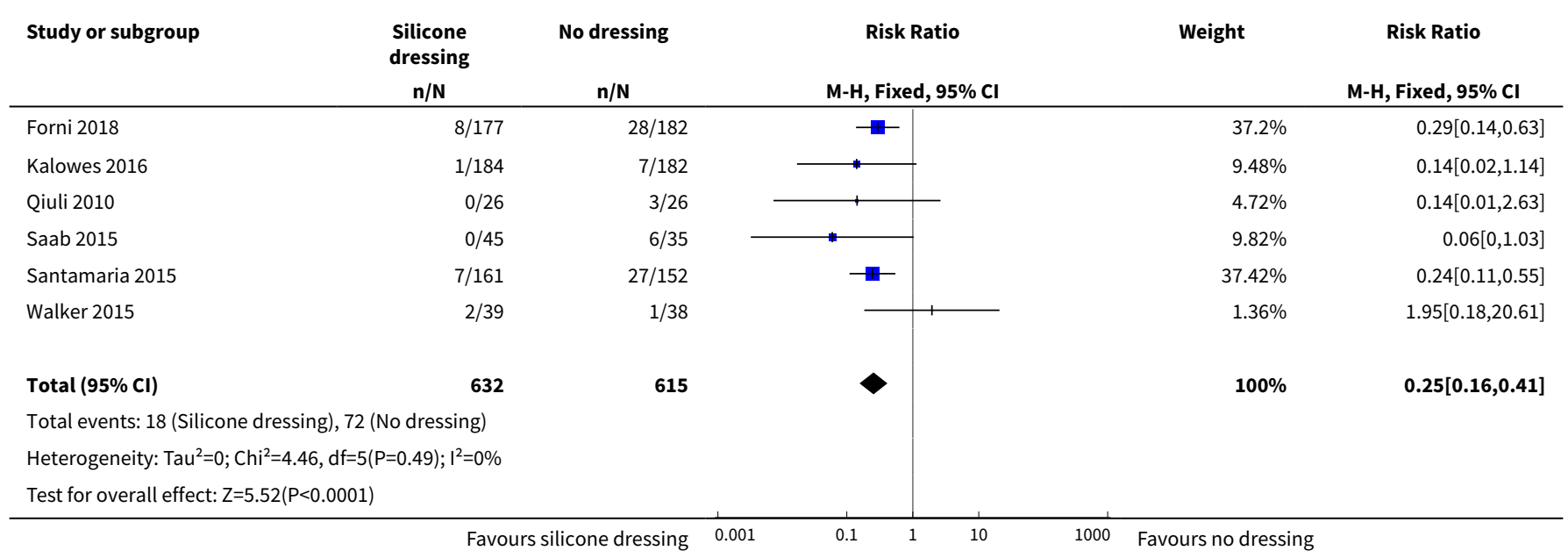

Analysis 3.2. Comparison 3 Silicone dressing versus no dressing, Outcome 2 Pressure ulcer (high-quality studies).

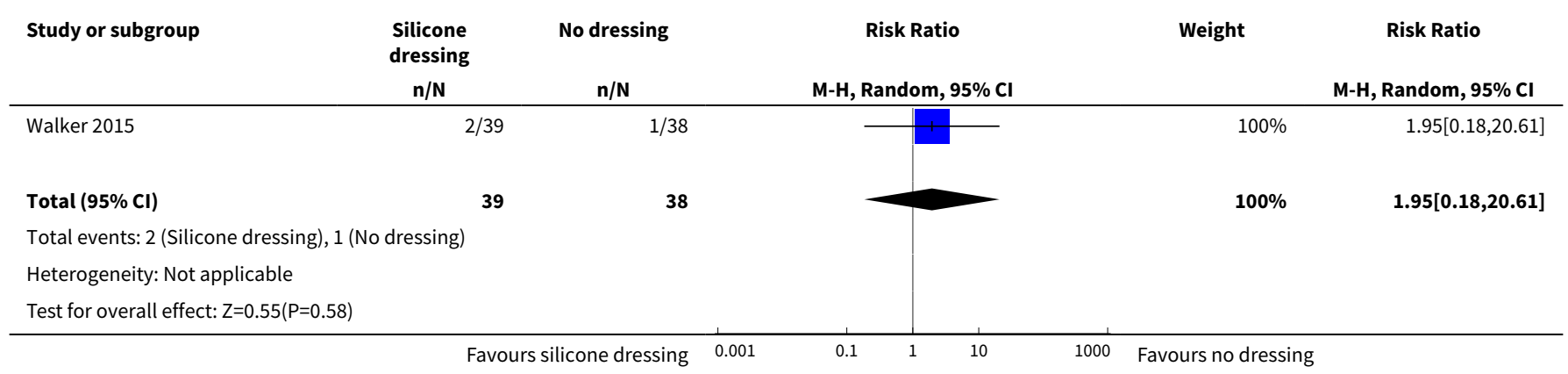

Analysis 3.3. Comparison 3 Silicone dressing versus no dressing, Outcome 3 Pressure ulcer stage.

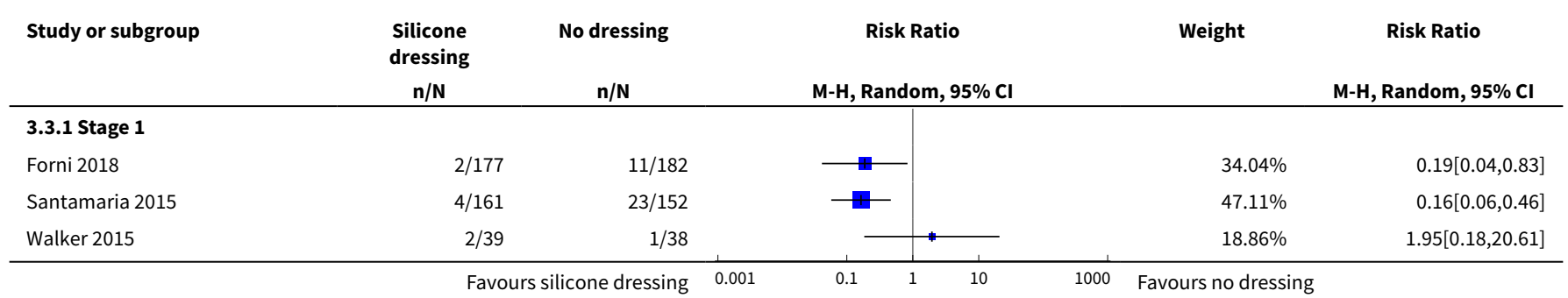




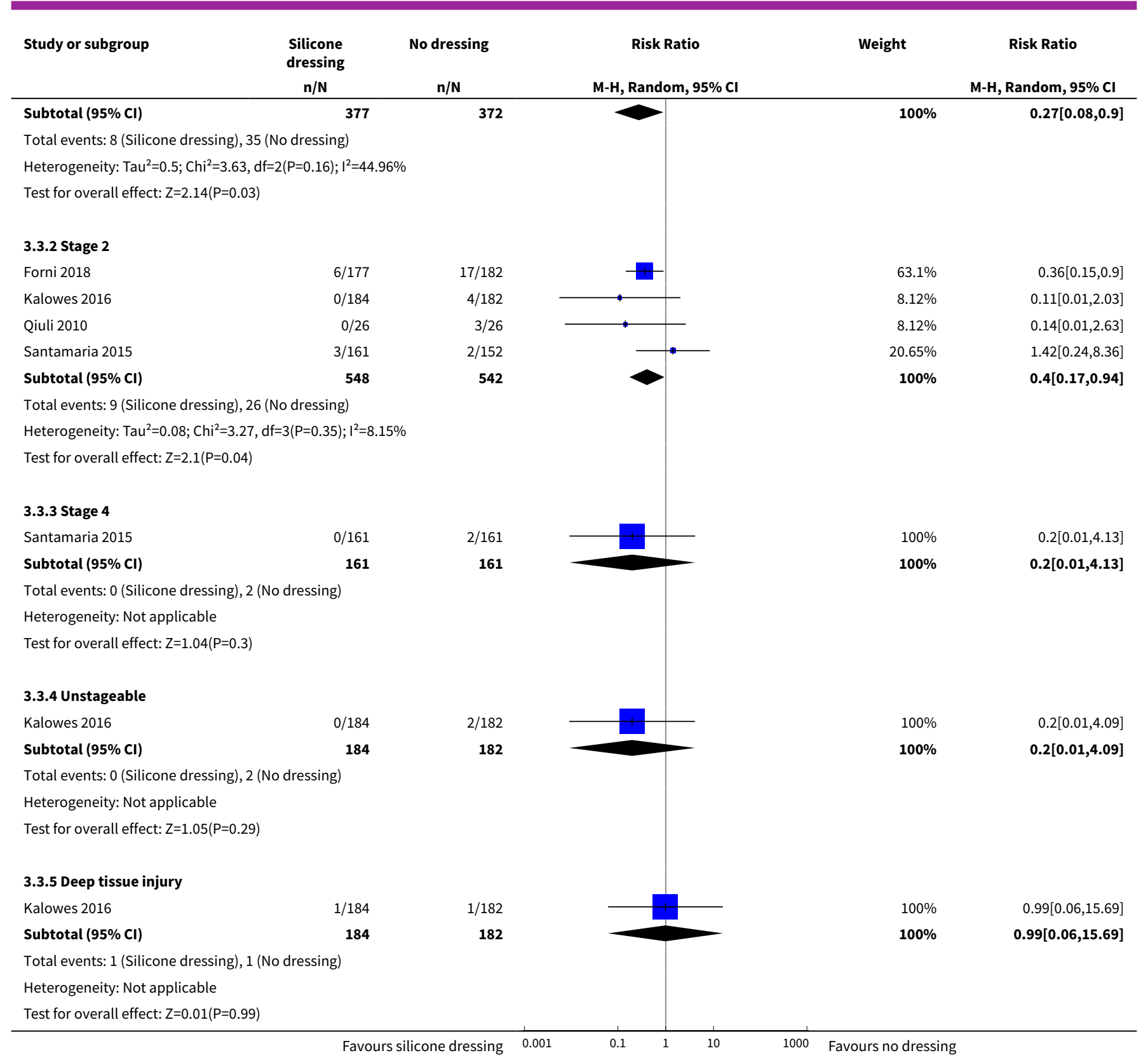

\section{Comparison 4. Other dressing versus control}

\begin{tabular}{lllll}
\hline Outcome or subgroup title & No. of studies & $\begin{array}{l}\text { No. of partici- } \\
\text { pants }\end{array}$ & Statistical method & Effect size \\
\hline 1 Pressure ulcer & 4 & & $\begin{array}{l}\text { Risk Ratio (M-H, Fixed, 95\% } \\
\mathrm{Cl})\end{array}$ & Subtotals only \\
\hline $\begin{array}{l}1.1 \text { Polyurethane film versus hydro- } \\
\text { colloid }\end{array}$ & 1 & 160 & $\begin{array}{l}\text { Risk Ratio (M-H, Fixed, 95\% } \\
\mathrm{Cl})\end{array}$ & $0.58[0.24,1.41]$ \\
\hline $\begin{array}{l}1.2 \text { Kang' huier versus routine care } \\
\text { n }\end{array}$ & 1 & 100 & $\begin{array}{l}\text { Risk Ratio (M-H, Fixed, 95\% } \\
\mathrm{Cl})\end{array}$ & $0.42[0.08,2.05]$ \\
\hline
\end{tabular}

Dressings and topical agents for preventing pressure ulcers (Review) 


\begin{tabular}{lllll}
\hline Outcome or subgroup title & No. of studies & $\begin{array}{l}\text { No. of partici- } \\
\text { pants }\end{array}$ & Statistical method & Effect size \\
\hline 1.3 PPD versus no dressing & 1 & 74 & $\begin{array}{l}\text { Risk Ratio (M-H, Fixed, 95\% } \\
\text { Cl) }\end{array}$ & $0.18[0.04,0.76]$ \\
\hline $\begin{array}{l}\text { 1.4 Thin polyurethane foam versus no } \\
\text { dressing }\end{array}$ & 1 & 74 & $\begin{array}{l}\text { Risk Ratio (M-H, Fixed, 95\% } \\
\text { Cl) }\end{array}$ & $1.31[0.83,2.07]$ \\
\hline $\begin{array}{l}\text { 1.5 Adhesive foam dressing versus no } \\
\text { dressing }\end{array}$ & 1 & 78 & $\begin{array}{l}\text { Risk Ratio (M-H, Fixed, 95\% } \\
\text { Cl) }\end{array}$ & $1.65[1.10,2.48]$ \\
\hline
\end{tabular}

Analysis 4.1. Comparison 4 Other dressing versus control, Outcome 1 Pressure ulcer.

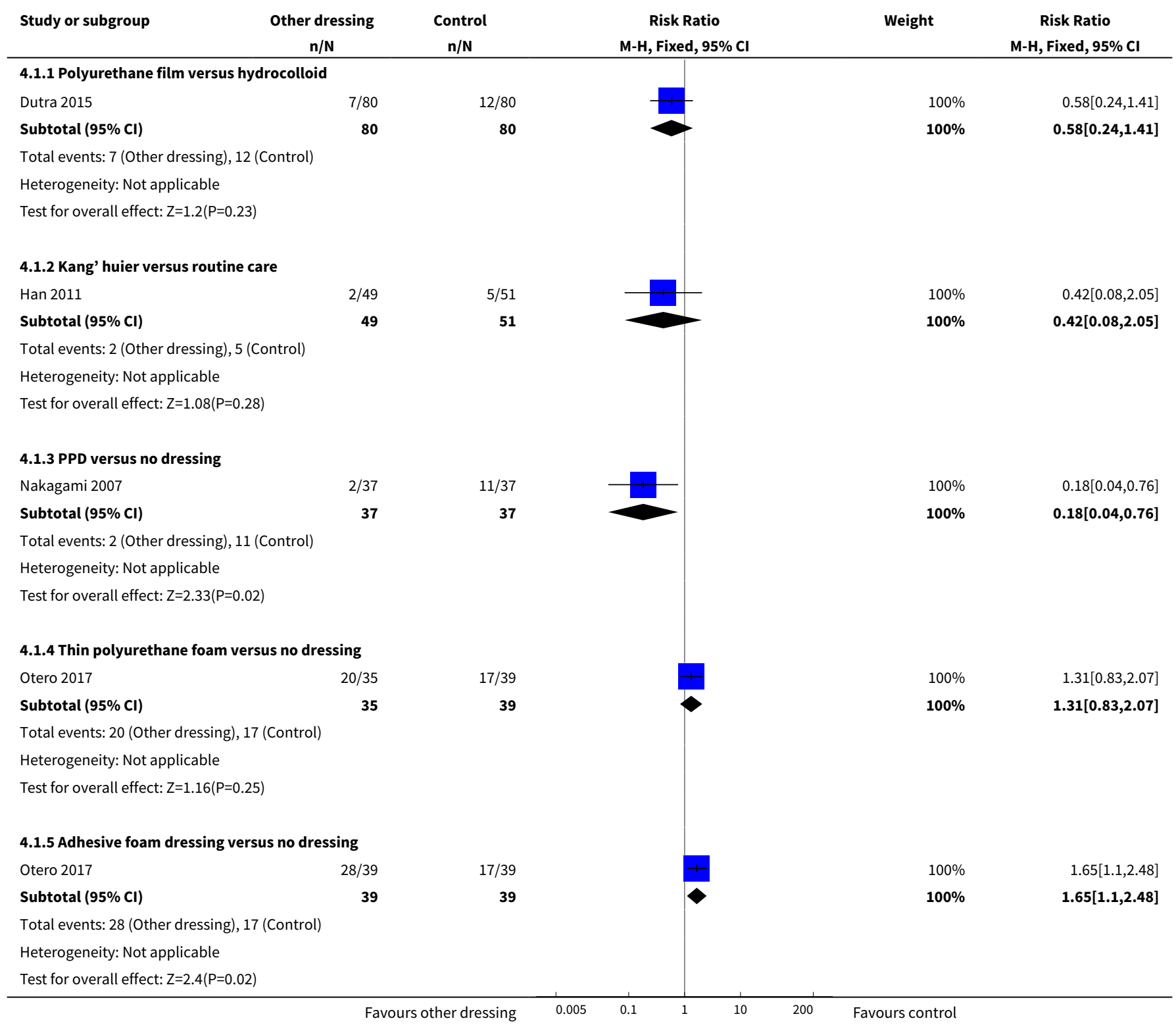




\section{ADDITIONAL TABLES}

Table 1. Intervention topical agents and dressings

\begin{tabular}{ll}
\hline Trial (author/year) & Topical agents \\
\hline Chiew 2010 & $\begin{array}{l}\text { Sanyrene } \\
\text { fatty acids }\end{array}$ \\
\hline Diaz-Valenzuela 2014 & $\begin{array}{l}\text { Mepentol, a hyperoxygenated fatty acid compound } \\
\text { consisting of oleic acid, palmitic acid, stearic acid, } \\
\text { palmitoleic acid, linoleic acid, gamma linoleic acid, } \\
\text { arachidonic acid, and eicosenoic acid }\end{array}$ \\
\hline
\end{tabular}

Dutra 2015

Polyurethane film

Hydrocolloid dressing

Forni 2018

Multi-layered design incorporating hydrocellular foam, hyper-absorber, lock-away core with a silicone wound contact layer

\begin{tabular}{ll}
\hline Green 1974 & Dermalex ${ }^{\mathrm{TM}}$ : consisting of hexachlorophane $0.5 \%$, squa- \\
lene (Cosbiol $3 \%)$, and allantoin $0.2 \%$, lanolin, fatty \\
acids, fatty alcohols, and antioxidants
\end{tabular}

Han 2011

Kang' huier transparent strip and foam dressing

\begin{tabular}{lll}
\hline Houwing 2008 & $\begin{array}{l}\text { DMSO-cream: consisting of 5\% dimethyl sulfoxide in } \\
\text { Vaseline-cetomacrogol cream }\end{array}$ \\
\hline Kalowes 2016 & $\begin{array}{l}\text { Soft silicone, self adherent, bordered multilay- } \\
\text { er foam dressing }\end{array}$ \\
\hline
\end{tabular}

Lupianez-Perez $2015 \quad$ Hyperoxygenated fatty acids product

An olive oil product

\section{Nakagami 2007}

Otero $2017 \quad$ Group D. Hyperoxygenated fatty acids, containing linoleic acid $60-70 \%$

PPD ((pressure ulcer preventive dressing) dressing with skin adhesive layer (hydrocolloid), a support layer (urethane film) and an outer layer of multi filament nylon fibres)

Group D. Hyperoxygenated fatty acids, containing
linoleic acid $60-70 \%$

Group B: Adhesive thin polyurethane foam dressing (Allevyn thin; Smith \& Nephew)

Group C: Adhesive foam dressings (Askina Foam; B. Braun)

\section{Qiuli 2010}

Soft silicone, self-adherent, bordered multilayer foam dressing

\section{Saab 2015}

Multi-layered design incorporating hydrocellular foam, hyper-absorber, lock-away core with a silicone wound contact layer 
Table 1. Intervention topical agents and dressings (Continued)

\begin{tabular}{|c|c|}
\hline Smith 1985 & $\begin{array}{l}\text { Conotrane: consisting of a silicone cream, } 20 \% \text { dime- } \\
\text { thicone } 350 \text {, and a broad-spectrum antiseptic }(0.05 \% \\
\text { hydrargaphen) }\end{array}$ \\
\hline Torra i Bou 2005 & $\begin{array}{l}\text { Mepentol: a hyperoxygenated fatty acid compound } \\
\text { consisting of oleic acid, palmitic acid, stearic acid, } \\
\text { palmitoleic acid, linoleic acid, gamma linoleic acid, } \\
\text { arachidonic acid, and eicosenoic acid }\end{array}$ \\
\hline Van Der Cammen 1987 & $\begin{array}{l}\text { Prevasore: consisting of hexyl nicotinate, zinc stearate, } \\
\text { isopropyl myristate, dimethicone } 350, \text { cetrimide and } \\
\text { glycol }\end{array}$ \\
\hline Walker 2015 & \\
\hline
\end{tabular}

\section{APPENDICES}

\section{Appendix 1. International NPUAP-EPUAP pressure ulcer classification system for ulcer grading}

\section{Category/Stage 1: non-blanchable redness of intact skin}

Intact skin with non-blanchable erythema of a localised area usually over a bony prominence. Discolouration of the skin, warmth, oedema, hardness or pain may also be present. Darkly pigmented skin may not have visible blanching. Further description: the area may be painful, firm, soft, warmer or cooler than adjacent tissue. Category/stage 1 may be difficult to detect in individuals with dark skin tones. May indicate 'at risk' individuals.

\section{Category/Stage 2: partial thickness skin loss or blister}

Partial thickness loss of dermis presenting as a shallow open ulcer with a red pink wound bed, without slough. May also present as an intact or open/ruptured serum-filled or sero-sanguinous-filled blister. Further description: presents as a shiny or dry shallow ulcer without slough or bruising. This category/stage should not be used to describe skin tears, tape burns, incontinence associated dermatitis, maceration or excoriation.

\section{Category/Stage 3: full thickness skin loss (fat visible)}

Full thickness tissue loss. Subcutaneous fat may be visible but bone, tendon or muscle are not exposed. Some slough may be present. May include undermining and tunnelling. Further description: the depth of a Category/stage 3 pressure ulcer varies by anatomical location. The bridge of the nose, ear, occiput and malleolus do not have (adipose) subcutaneous tissue and category/stage 3 ulcers can be shallow. In contrast, areas of significant adiposity can develop extremely deep category/stage 3 pressure ulcers. Bone/tendon is not visible or directly palpable.

\section{Category/Stage 4: full thickness tissue loss (muscle/bone visible)}

Full thickness tissue loss with exposed bone, tendon or muscle. Slough or eschar may be present. Often include undermining and tunnelling.Further description: the depth of a category/stage 4 pressure ulcer varies by anatomical location. The bridge of the nose, ear, occiput and malleolus do not have (adipose) subcutaneous tissue and these ulcers can be shallow. Category/stage 4 ulcers can extend into muscle and/or supporting structures (e.g. fascia, tendon or joint capsule) making osteomyelitis or osteitis likely to occur. Exposed bone/ muscle is visible or directly palpable.

\section{Appendix 2. CENTRAL search strategy}

\#1 MeSH descriptor: [Biological Dressings] explode all trees

\#2 MeSH descriptor: [Occlusive Dressings] explode all trees \#3 MeSH descriptor: [Hydrogels] explode all trees \#4 MeSH descriptor: [Alginates] explode all trees \#5 dressing*:ti,ab,kw \#6 (hydrocolloid* or alginate* or hydrogel ${ }^{\star}$ or foam or bead or film or films or tulle or gauze or non-adherent or non adherent):ti,ab,kw \#7 MeSH descriptor: [Anti-Bacterial Agents] explode all trees \#8 MeSH descriptor: [Administration, Topical] explode all trees 
\#9 \#7 and \#8

\#10 (topical near/2 antibiotic ${ }^{\star}$ ):ti,ab

\#11 MeSH descriptor: [Anti-Infective Agents, Local] explode all trees

\#12 MeSH descriptor: [Anti-Inflammatory Agents] explode all trees

\#13 MeSH descriptor: [Glucocorticoids] explode all trees

\#14 \#12 or \#13

$\# 15$ \#8 and \#14

\#16 (topical near/2 (steroid* or corticosteroid ${ }^{\star}$ or glucocorticoid*)):ti,ab,kw

$\# 17 \mathrm{MeSH}$ descriptor: [Estrogens] explode all trees

\#18 \#8 and \#17

\#19 (topical near/2 (oestrogen or estrogen)):ti,ab,kw

\#20 MeSH descriptor: [Enzymes] explode all trees

\#21 \#8 and \#20

\#22 (topical near/2 enzym*):ti,ab,kw

\#23 MeSH descriptor: [Growth Substances] explode all trees

\#24 \#8 and \#23

\#25 (topical near/2 growth factor $\left.{ }^{\star}\right)$ :ti,ab,kw

\#26 MeSH descriptor: [Collagen] explode all trees

\#27 \#8 and \#26

\#28 (topical near/2 collagen):ti,ab,kw

\#29 (topical near/2 silver):ti,ab

\#30 MeSH descriptor: [Ointments] explode all trees

\#31 (ointment* or lotion* or cream*):ti,ab,kw

\#32 MeSH descriptor: [Honey] explode all trees

\#33 honey.ti,ab,kw

\#34 (topical next (agent* or preparation* or therap* or treatment $\left.{ }^{\star}\right)$ ):ti,ab,kw

$\# 35$ (\#1 or \#2 or \#3 or \#4 or \#5 or \#6 or \#9 or \#10 or \#11 or \#15 or \#16 or \#18 or \#19 or \#21 or \#22 or \#24 or \#25 or \#27 or \#28 or \#29 or \#30 or \#31 or \#32 or \#33 or \#34)

\#36 MeSH descriptor: [Pressure Ulcer] explode all trees

\#37 pressure next (ulcer* or sore*):ti,ab,kw

\#38 decubitus next (ulcer ${ }^{\star}$ or sore ${ }^{\star}$ ):ti,ab,kw

\#39 (bed next sore*) or bedsore*:ti,ab,kw

$\# 40$ (\#36 or \#37 or \#38 or \#39)

$\# 41 \# 35$ and \#40

\section{Appendix 3. Ovid MEDLINE, Ovid Embase and EBSCO CINAHL search strategies}

\section{Ovid Medline}

1 exp Biological Dressings/ (590)

2 exp Occlusive Dressings/ (1560)

3 exp Hydrogels/ (7950)

4 exp Alginates/ (4561)

5 dressing\$.ti,ab. (7994)

6 (hydrocolloid\$ or alginate\$ or hydrogel\$ or foam or bead or film or films or tulle or gauze or non-adherent or non adherent).ti,ab. (72393)

7 exp Anti-Bacterial Agents/ (215334)

8 exp Administration, Topical/ (41359)

9 and/7-8 (2703)

10 (topical adj2 antibiotic\$).ti,ab. (1112)

11 exp Antiinfective Agents, Local/ (83845)

$12 \exp$ Anti-Inflammatory Agents/ (180341)

13 exp Glucocorticoids/ (71762)

14 or/12-13 (191854)

158 and 14 (6251)

16 (topical adj2 (steroid\$ or corticosteroid\$ or glucocorticoid\$)).ti,ab. (4415)

17 exp Estrogens/ (57995)

188 and 17 (1634)

19 (topical adj2 (oestrogen or estrogen)).ti,ab. (77)

20 exp Enzymes/ (1289849)

218 and 20 (2786)

22 (topical adj2 enzym\$).ti,ab. (14)

23 exp Growth Substances/ (290263)

248 and 23 (1738)

Dressings and topical agents for preventing pressure ulcers (Review) 
25 (topical adj2 growth factor\$).ti,ab. (55)

26 exp Collagen/ (52416)

278 and 26 (315)

28 (topical adj2 collagen).ti,ab. (17)

29 (topical adj2 silver).ti,ab. (62)

30 exp Honey/ (1486)

31 honey\$.ti,ab. (7191)

32 exp Ointments/ (3714)

33 (ointment\$ or lotion\$ or cream\$).ti,ab. (11253)

34 (topical adj (agent\$ or preparation\$ or therap\$ or treatment\$)).ti,ab. (5368)

35 or/1-6,9-11,15-16,18-19,21-22,24-25,27-34 (198846)

36 exp Pressure Ulcer/ (5267)

37 (pressure adj (ulcer\$ or sore\$)).ti,ab. (4400)

38 (decubitus adj (ulcer\$ or sore\$)).ti,ab. (585)

39 (bedsore $\$$ or (bed adj sore\$)).ti,ab. (245)

40 or/36-39 (6597)

4135 and 40 (679)

42 randomized controlled trial.pt. (243536)

43 controlled clinical trial.pt. (39760)

44 randomized.ab. (198232)

45 placebo.ab. (92274)

46 clinical trials as topic.sh. (80060)

47 randomly.ab. (136251)

48 trial.ti. (73632)

49 or/42-48 (549699)

50 Animals/ (2494493)

51 Humans/ (6922271)

5250 not $51(1627525)$

5349 not 52 (500327)

5441 and 53 (151)

\section{Ovid Embase}

1 exp foam dressing/ (181)

2 exp gauze dressing/ (799)

3 exp hydrocolloid dressing/ (454)

4 exp hydrogel dressing/ (147)

5 exp Wound Dressing/ (6673)

6 exp Hydrogel/ (13683)

7 exp Calcium Alginate/ (1232)

8 dressing $\$$.ti,ab. (11539)

9 (hydrocolloid\$ or alginate\$ or hydrogel\$ or foam or bead or film or films or tulle or gauze or non-adherent or non adherent).ti,ab. (110602)

10 exp Antibiotic Agent/ (543716)

11 exp Topical Drug Administration/ (14698)

12 and/10-11 (2182)

13 (topical adj2 antibiotic\$).ti,ab. (1608)

14 exp Antiinfective Agent/ (1331673)

1511 and 14 (5355)

16 exp Antiinflammatory Agent/ (743751)

17 exp Corticosteroid/ (401726)

18 exp Glucocorticoid/ (311297)

19 or/16-18 (830153)

2011 and 19 (4840)

21 (topical adj2 (steroid\$ or corticosteroid\$ or glucocorticoid\$)).ti,ab. (7159)

22 exp Estrogen/ (118910)

2311 and 22 (207)

24 (topical adj2 (oestrogen or estrogen)).ti,ab. (149)

25 exp Enzymes/ (1821631)

2611 and 25 (898)

27 (topical adj2 enzym\$).ti,ab. (19)

28 exp Growth Factor/ (318023)

2911 and 28 (299) 
30 (topical adj2 growth factor\$).ti,ab. (72)

31 exp Collagen/ (96769)

3211 and 31 (209)

33 (topical adj2 collagen).ti,ab. (21)

34 (topical adj2 silver).ti,ab. (90)

35 exp Honey/ (2696)

36 honey\$.ti,ab. (10147)

37 exp Ointments/ (4759)

38 (ointment\$ or lotion\$ or cream\$).ti,ab. (18505)

39 (topical adj (agent\$ or preparation\$ or therap\$ or treatment $\left.{ }^{\star}\right)$ ).ti,ab. (8287)

40 or/1-9,12-13,15,20-21,23-24,26-27,29-30,32-39 (173972)

41 exp Decubitus/ (9199)

42 (pressure adj (ulcer\$ or sore\$)).ti,ab. (5687)

43 (decubitus adj (ulcer\$ or sore\$)).ti,ab. (781)

44 (bedsore $\$$ or (bed adj sore\$)).ti,ab. (415)

45 or/41-44 (10385)

4640 and $45(1126)$

47 exp Clinical trial/ (793074)

48 Randomized controlled trial/ (286529)

49 Randomization/ (50655)

50 Single blind procedure/ (15585)

51 Double blind procedure/ (85986)

52 Crossover procedure/ (31907)

53 Placebo/ (165507)

54 Randomi?ed controlled trial\$̦.tw. (80377)

55 RCT.tw. (10556)

56 Random allocation.tw. (910)

57 Randomly allocated.tw. (14266)

58 Allocated randomly.tw. (1214)

59 (allocated adj2 random).tw. (264)

60 Single blind\$.tw. (9677)

61 Double blind\$.tw. (90376)

62 ((treble or triple) adj blind\$).tw. (239)

63 Placebo\$.tw. (137423)

64 Prospective study/ (200692)

65 or/47-64 (1088348)

66 Case study/ (15964)

67 Case report.tw. (167009)

68 Abstract report/ or letter/ (511635)

69 or/66-68 (690338)

7065 not 69 (1060158)

71 animal/ (725145)

72 human/ (8645166)

7371 not 72 (484830)

7470 not $73(1037853)$

7546 and 74 (309)

\section{EBSCO CINAHL}

S39 S33 and S38

S38 S34 or S35 or S36 or S37

S37 TI decubitus or $A B$ decubitus

S36 TI ( bed sore* or bedsore* ) or AB ( bed sore* or bedsore* )

S35 TI ( pressure ulcer ${ }^{\star}$ or pressure sore* ) or $A B$ ( pressure ulcer $^{\star}$ or pressure sore ${ }^{\star}$ )

S34 (MH "Pressure Ulcer")

$\mathrm{S} 33 \mathrm{~S} 1$ or $\mathrm{S} 2$ or $\mathrm{S} 3$ or $\mathrm{S} 6$ or $\mathrm{S} 7$ or $\mathrm{S} 8$ or $\mathrm{S} 9$ or $\mathrm{S} 10$ or $\mathrm{S} 12$ or $\mathrm{S} 13$ or $\mathrm{S} 15$ or $\mathrm{S} 16$ or $\mathrm{S} 18$ or $\mathrm{S} 19$ or $\mathrm{S} 21$ or $\mathrm{S} 22$ or $\mathrm{S} 26$ or $\mathrm{S} 27$ or $\mathrm{S} 28$ or $\mathrm{S} 29$ or $\mathrm{S} 30$ or S31 or S32

S32 TI ( topical agent* or topical preparation* or topical therap ${ }^{\star}$ or topical treatment ${ }^{\star}$ ) or AB ( topical agent* or topical preparation* or topical therap* or topical treatment ${ }^{\star}$ )

S31 $\mathrm{TI}$ ( ointment ${ }^{\star}$ or lotion* or cream* ) or AB ( ointment ${ }^{\star}$ or lotion* or cream* ${ }^{\star}$ )

S30 (MH "Ointments")

S29 TI honey* or AB honey* 
S28 (MH "Honey")

S27 TI topical ${ }^{*}$ N2 silver* or AB topical ${ }^{*}$ N2 silver*

S26 S5 and S25

S25 S23 or S24

S24 (MH "Silver Sulfadiazine")

S23 (MH "Silver")

S22 TI collagen* or AB collagen*

S21 S5 and S20

S20 (MH "Collagen")

S19 TI topical ${ }^{\star}$ N2 growth factor ${ }^{\star}$ or AB topical ${ }^{*}$ N2 growth factor ${ }^{*}$

S18 (S5 and S17)

S17 (MH "Growth Substances+")

S16 TI topical ${ }^{\star}$ N2 enzyme* or AB topical ${ }^{*}$ N2 enzyme*

S15 S5 and S14

S14 (MH "Enzymes+")

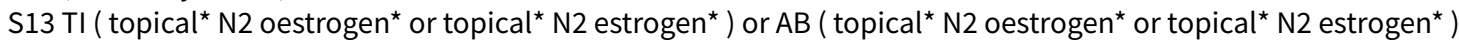

S12 S5 and S11

$\mathrm{S} 11$ (MH "Estrogens+")

S10 TI ( topical* N2 steroid* or topical* N2 corticosteroid* or topical ${ }^{\star}$ N2 glucocorticoid* ) or AB ( topical ${ }^{\star}$ N2 steroid* or topical ${ }^{\star}$ N2 corticosteroid ${ }^{\star}$ or topical ${ }^{\star} \mathrm{N} 2$ glucocorticoid $^{\star}$ )

S9 (MH "Antiinflammatory Agents, Topical+")

S8 (MH "Antiinfective Agents, Local+")

S7 TI topical ${ }^{*}$ N2 antibiotic $^{*}$ or AB topical ${ }^{*}$ N2 antibiotic* $^{*}$

$\mathrm{S} 6 \mathrm{~S} 4$ and $\mathrm{S} 5$

S5 MH "Administration, Topical+")

S4 (MH "Antibiotics+")

S3 TI ( dressing* or pad or pads or gauze or tulle or film or bead or foam* or non-adherent or non adherent or hydrocolloid* or alginat* or hydrogel ${ }^{\star}$ ) or AB (dressing* or pad or pads or gauze or tulle or film or bead or foam* or non-adherent or non adherent or hydrocolloid ${ }^{\star}$ or alginat ${ }^{\star}$ or hydrogel $\left.{ }^{*}\right)$

S2 (MH "Alginates")

$\mathrm{S} 1$ (MH "Bandages and Dressings+")

\section{Appendix 4. 'Risk of bias' criteria}

\section{Was the allocation sequence randomly generated?}

\section{Low risk of bias}

The investigators describe a random component in the sequence generation process such as: referring to a random number table; using a computer random number generator; coin tossing; shuffling cards or envelopes; throwing dice; drawing of lots.

\section{High risk of bias}

The investigators describe a non-random component in the sequence generation process. Usually, the description would involve some systematic, non-random approach, for example: sequence generated by odd or even date of birth; sequence generated by some rule based on date (or day) of admission; sequence generated by some rule based on hospital or clinic record number.

\section{Unclear}

Insufficient information about the sequence generation process provided to permit a judgement of low or high risk of bias.

\section{Was the treatment allocation adequately concealed?}

\section{Low risk of bias}

Participants and investigators enrolling participants could not foresee assignment because one of the following, or an equivalent method, was used to conceal allocation: central allocation (including telephone, web-based and pharmacy-controlled randomisation); sequentially-numbered drug containers of identical appearance; sequentially-numbered, opaque, sealed envelopes.

\section{High risk of bias}

Participants or investigators enrolling participants could possibly foresee assignments and thus introduce selection bias, such as allocation based on: use of an open random allocation schedule (e.g. a list of random numbers); assignment envelopes without appropriate safeguards (e.g. envelopes were unsealed, non-opaque, or not sequentially numbered); alternation or rotation; date of birth; case record number; any other explicitly unconcealed procedure. 


\section{Unclear}

Insufficient information provided to permit a judgement of low or high risk of bias. This is usually the case if the method of concealment is not described, or not described in sufficient detail to allow a definite judgement, for example if the use of assignment envelopes is described, but it remains unclear whether envelopes were sequentially numbered, opaque and sealed.

\section{Blinding - was knowledge of the allocated interventions adequately prevented during the study?}

\section{Low risk of bias}

Any one of the following.

- No blinding, but the review authors judge that the outcome and the outcome measurement are not likely to be influenced by lack of blinding.

- Blinding of participants and key study personnel ensured, and unlikely that the blinding could have been broken.

- Either participants or some key study personnel were not blinded, but outcome assessment was blinded and the non-blinding of others unlikely to introduce bias.

\section{High risk of bias}

Any one of the following.

- No blinding or incomplete blinding, and the outcome or outcome measurement is likely to be influenced by lack of blinding.

- Blinding of key study participants and personnel attempted, but likely that the blinding could have been broken.

- Either participants or some key study personnel were not blinded, and the non-blinding of others likely to introduce bias.

\section{Unclear}

Either of the following.

- Insufficient information to permit judgement of low or high risk of bias.

- The study did not address this outcome.

\section{Were incomplete outcome data adequately addressed?}

\section{Low risk of bias}

Any one of the following.

- No missing outcome data.

- Reasons for missing outcome data are unlikely to be related to true outcome (for survival data, censoring unlikely to be introducing bias).

- Missing outcome data are balanced in numbers across intervention groups, with similar reasons for missing data across groups.

- For dichotomous outcome data, the proportion of missing outcomes compared with the observed event risk is not enough to have a clinically relevant impact on the intervention effect estimate.

- For continuous outcome data, a plausible effect size (difference in means or standardised difference in means) among missing outcomes is not enough to have a clinically relevant impact on the observed effect size.

- Missing data have been imputed using appropriate methods.

\section{High risk of bias}

Any one of the following.

- Reason for missing outcome data are likely to be related to the true outcome, with either an imbalance in numbers or reasons for missing data across intervention groups.

- For dichotomous outcome data, the proportion of missing outcomes compared with the observed event risk is enough to induce clinically relevant bias in the intervention effect estimate.

- For continuous outcome data, a plausible effect size (difference in means or standardised difference in means) among missing outcomes is enough to induce a clinically relevant bias in the observed effect size.

- 'As-treated' analysis done with a substantial departure of the intervention received from that assigned at randomisation.

- Potentially inappropriate application of simple imputation.

\section{Unclear}

Either of the following. 
- Insufficient reporting of attrition/exclusions to permit a judgement of low or high risk of bias (e.g. number randomised not stated, no reasons for missing data provided).

- The study did not address this outcome.

\section{Are reports of the study free of suggestion of selective outcome reporting?}

\section{Low risk of bias}

Either of the following.

- The study protocol is available and all of the study's prespecified (primary and secondary) outcomes that are of interest in the review have been reported in the prespecified way.

- The study protocol is not available but it is clear that the published reports include all expected outcomes, including those that were prespecified (convincing text of this nature may be uncommon).

\section{High risk of bias}

Any one of the following.

- Not all of the study's prespecified primary outcomes have been reported.

- One or more primary outcomes is/are reported using measurements, analysis methods, or subsets of the data (e.g. subscales) that were not prespecified.

- One or more reported primary outcomes was/were not prespecified (unless clear justification for their reporting is provided, such as an unexpected adverse effect).

- One or more outcomes of interest in the review is/are reported incompletely so that they cannot be entered in a meta-analysis.

- The study report fails to include results for a key outcome that would be expected to have been reported for such a study.

\section{Unclear}

Insufficient information provided to permit a judgement of low or high risk of bias. It is likely that the majority of trials will fall into this category.

\section{Other sources of potential bias}

\section{Low risk of bias}

The study appears to be free of other sources of bias.

\section{High risk of bias}

There is at least one important risk of bias. For example, the study:

- had a potential source of bias related to the specific study design used; or

- has been claimed to have been fraudulent; or

- had some other problem.

\section{Unclear}

There may be a risk of bias, but there is either:

- insufficient information to assess whether an important risk of bias exists; or

- insufficient rationale or evidence that an identified problem will introduce bias.

\section{WHAT'S NEW}

\begin{tabular}{lll}
\hline Date & Event & Description \\
\hline 30 November 2018 & $\begin{array}{l}\text { New citation required and conclusions } \\
\text { have changed }\end{array}$ & Updated. Conclusions changed \\
\hline 30 November 2018 & New search has been performed & $\begin{array}{l}\text { First update. New search with nine trials added. Content up- } \\
\text { dated, conclusions changed. The search was updated in May } \\
2018 \text { and six trials were added to Studies awaiting classification }\end{array}$
\end{tabular}




\begin{tabular}{lll}
\hline Date Event Description & Den
\end{tabular}

(Aloweni 2017; Guo 2015; Imbulana 2018; Kim 2016; Tai 2016;

Wang 2016).

\section{CONTRIBUTIONSOF AUTHORS}

Zena Moore: conceived the review; designed and coordinated the review update; extracted data; checked the quality of data extraction; analysed or interpreted data; undertook and checked quality assessment; performed statistical analysis; checked the quality of the statistical analysis; produced the first draft of the review update; contributed to writing and editing the review update; approved the final review update prior to submission and is a guarantor of the review update.

Joan Webster: conceived the review; designed and coordinated the review update; extracted data; checked the quality of data extraction; analysed or interpreted data; undertook and checked quality assessment; performed statistical analysis; checked the quality of the statistical analysis; produced the first draft of the review update; contributed to writing and editing the review update; wrote to trial authors/experts/companies and approved the final review update prior to submission.

\section{Contributions of the editorial base}

Jo Dumville (Coordinating Editor): edited the review, advised on methodology, interpretation and review content; approved the final review update prior to submission.

Gill Rizzello (Managing Editor): coordinated the editorial process; advised on content; edited the review update.

Naomi Shaw (Information Specialist): designed the search strategy, ran the searches and edited the search methods section.

Ursula Gonthier (Editorial Assistant): edited the Plain Language Summary and the reference sections of the review.

\section{DECLARATIONSOF INTEREST}

Zena Moore: has received an honorarium for speaking at a professional meeting for Smith \& Nephew and Molnlycke. The School of Nursing and Midwifery, RCSI has received a research grant from BSN Medical.

Joan Webster: none known.

\section{SOURCES OF SUPPORT}

\section{Internal sources}

- Faculty of Nursing \& Midwifery, RCSI, Ireland.

\section{External sources}

- National Institute for Health Research, UK.

This project was supported by the National Institute for Health Research, via Cochrane Infrastructure funding to Cochrane Wounds. The views and opinions expressed herein are those of the authors and do not necessarily reflect those of the Systematic Reviews Programme, NIHR, National Health Service or the Department of Health.

\section{DIFFERENCES BETWEEN PROTOCOL AND REVIEW}

- We added the words, "or any other intervention" under the heading 'Types of interventions.'

\section{Differences between this version of the review and the previous version}

- We added the words, 'we completed a PRISMA flowchart to summarise this process' to the section 'Selection of studies.'

- We added a section, 'Summary of findings table and GRADE assessment of the certainty of the evidence' to the Methods.

- We have changed the wording in the 'Unit of analysis issues' to, "Ideally a trial would be designed with participant-level randomisation and analysis, and only one pressure ulcer per participant (adjustment for clustering not necessary in this case), however, in pressure ulcer literature it is not unusual to find trials that report on multiple pressure ulcers per participant, randomised or analysed, or both, at wound level, and unadjusted for clustering. In such cases we planned to contact the trial authors and attempt to obtain: patient-level data or results; data or results for one pressure ulcer per participant; or pressure ulcer-level data, and then perform multilevel regression to calculate the adjusted effect. We would then have combined the adjusted results in the meta-analysis with those of participant-level trials (using the generic inverse method), and performed sensitivity analyses (Higgins 2011c). If we had been unsuccessful in obtaining the additional data required, then we would have excluded the trial from the meta-analysis." 


\section{N D EX TERMS}

\section{Medical Subject Headings (MeSH)}

*Bandages; Administration, Cutaneous; Allantoin [administration \& dosage]; Dimethyl Sulfoxide [administration \& dosage]; Drug Administration Schedule; Drug Combinations; Fatty Acids [administration \& dosage]; Hexachlorophene [administration \& dosage]; Incidence; Olive Oil [administration \& dosage]; Pressure Ulcer [epidemiology] [ ${ }^{\star}$ prevention \& control]; Randomized Controlled Trials as Topic; Silicones [administration \& dosage]; Skin Care [ ${ }^{*}$ methods]; Skin Cream [ ${ }^{\star}$ administration \& dosage] [chemistry]; Squalene [administration \& dosage]

\section{MeSH check words}

Aged; Humans; Middle Aged 